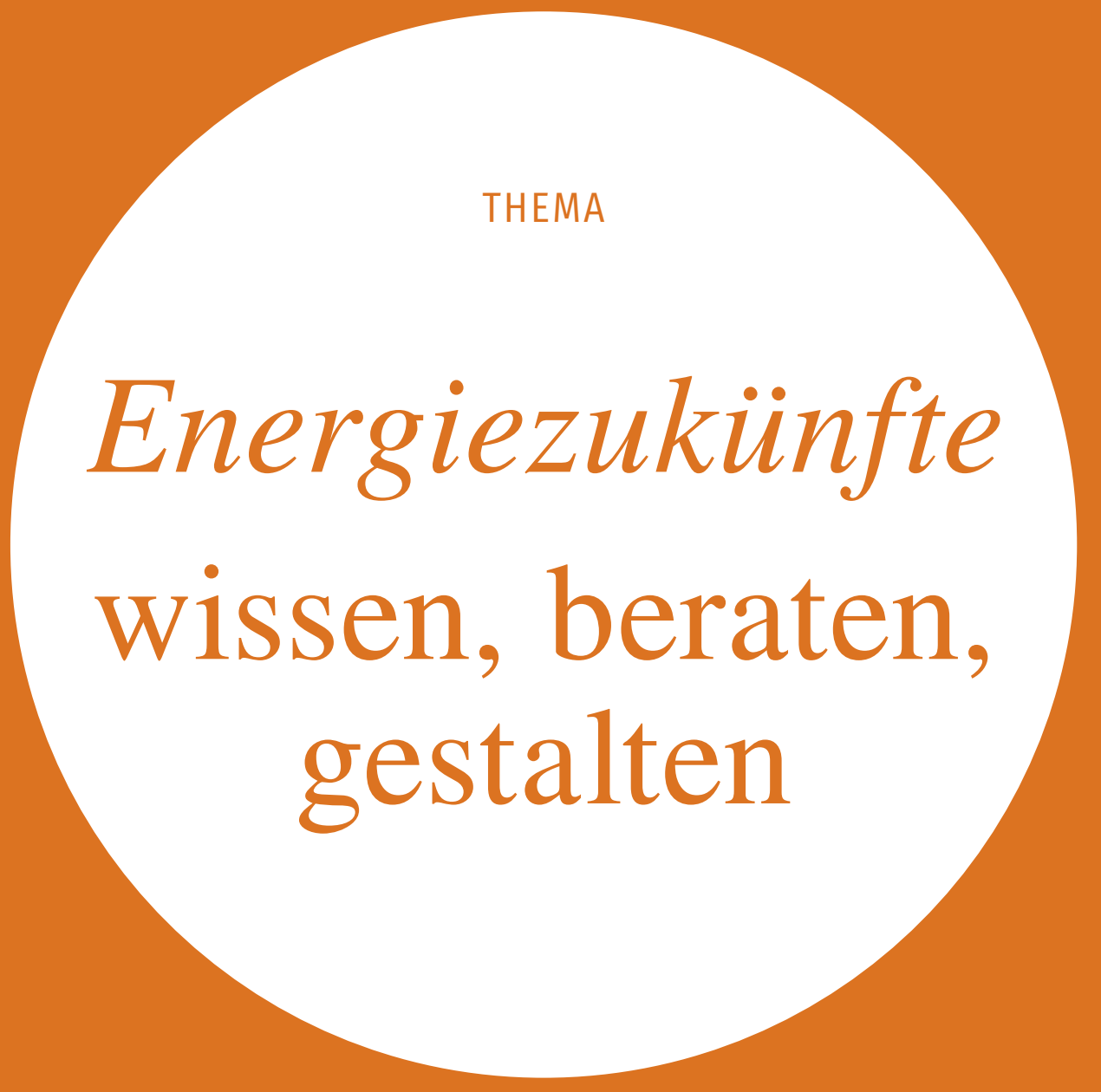

Wie kann die Transformation des Energiesystems gelingen? Die Wege dahin sind vielfältig und stellen eine zentrale Herausforderung dar.

Für die Wissenschaft stellt sich die Frage: Wie kann und wie soll relevantes Wissen über mögliche Zukunftspfade generiert und in den gesellschaftlichen Diskurs eingespeist werden? Ein TATuP-Thema herausgegeben von Dirk Scheer, Lisa Nabitz und Witold-Roger Poganietz 


\section{Energiezukünfte}

Wissen, beraten, gestalten

Dirk Scheer, Institut für Technikfolgenabschätzung und Systemanalyse (ITAS), Karlsruher Institut für Technologie (KIT), Karlstraße 11, 76133 Karlsruhe

(dirk.scheer@kit.edu) (1) https://orcid.org/0000-0002-7472-8331

Lisa Nabitz, Institut für Technikfolgenabschätzung und Systemanalyse (ITAS), Karlsruher Institut für Technologie (KIT) (lisa.nabitz@kit.edu)

Witold-Roger Poganietz, Institut für Technikfolgenabschätzung und Systemanalyse (ITAS), Karlsruher Institut für Technologie (KIT)

(witold-roger.poganietz@kit.edu) (1) https://orcid.org/0000-0002-5839-1206

Das vorliegende TATuP-Thema präsentiert mit empirischen und konzeptionellen Beiträgen neue und innovative Ansätze zur wissenschaftlichen Beschäftigung mit Energiezukünften aus den Blickwinkeln der inter- und transdisziplinären Zukunftsforschung, der Technikfolgenabschätzung und der Systemanalyse.

\section{Energy futures}

Knowing, advising, and shaping

This TATUP special topic presents new and innovative empirical and conceptual contributions that discuss approaches to research on energy futures from the perspectives of inter- and transdisciplinary future studies, technology assessment, and systems analysis.

Keywords: climate-friendly energy transition, future knowledge, socio-technical system

\section{Einführung}

Mit dem Ziel einer langfristigen Reduktion von Treibhausgasen nahe Null bis zum Jahr 2050 steht eine Transformation des Energiesystems national und global auf den Agenden wissenschaftlicher Forschung und politischer Entscheidung. Zentrale Triebfeder für den avisierten Umbau des Energiesystems ist die Problematik der anthropogen verursachten Erderwärmung und des Klimawandels (Meadowcroft 2009; Smil 2010).

Die deutsche Energiewende verdeutlicht in einem besonderen Maße den soziotechnischen Charakter von Energiesystemen (Schippl und Grunwald 2013; Schippl et al. 2017). Sie ist gekennzeichnet durch ambitionierte, prima facie technische Ziele wie beispielsweise den Ausstieg aus der Kohleverstromung, die Erhöhung des Anteils erneuerbarer Energien und die Senkung des Primärenergieverbrauchs (BMU 2016). Die Zielvorgabe der

This is an article distributed under the terms of the Creative Commons Attribution License CCBY 4.0 (https://creativecommons.org/licenses/by/4.0/)

https://doi.org/10.14512/tatup.28.3.11
Transformation des Energiesystems kann dabei allerdings nicht nur nach Maßgabe technisch-ökonomischer Machbarkeit bewertet werden. Die Energiewende wird ohne Zustimmung der Bevölkerung kaum erfolgreich umzusetzen sein, da die Rückversicherung durch die Bürger*innen in einer pluralistischdemokratischen Gesellschaft von zentraler Bedeutung ist und privates Entscheidungsverhalten den Transformationserfolg in erheblichen Maße mitbestimmt (Scheer et al. 2014). Der Umbau des Energiesystems ist zudem eine Operation ,im laufenden Betrieb" und muss unter Aufrechterhaltung eines möglichst vollständig funktions- und leistungsfähigen Energiesystems vonstattengehen.

Damit ist das Ziel eines klimaneutralen Energiesystems recht eindeutig vorgegeben - die Wege dahin bleiben allerdings vielfältig und heterogen. Selbst die Spezifizierung der Ziele der deutschen Energiewende lässt Spielraum für unterschiedliche Wege. Vor diesem Hintergrund wird Zukunft zu Zukünften. Aber was heißt eine Pluralisierung von Energiezukunft? Unter dem Begriff Energiezukünfte fassen wir die aus heutiger Sicht prinzipielle Offenheit des Energiesystemumbaus in jeweils unterschiedlich möglichen soziotechnischen Konfigurationen selbst unter eindeutiger Zielvorgabe (Grunwald 2011). Diese unterschiedlichen Konfigurationen basieren auf bestimmten Akzentuierungen im Zusammenspiel von Technik, Politik, Ökonomie und Gesellschaft. Diese Akzentuierungen sind zunächst erdachte und gemachte Zukunftsentwürfe auf dem Spektrum plausibler Zusammenhänge von Machbarkeit und Wünschbarkeit und konkretisieren sich in bestimmten Annahmen über spezifischen Technikeinsatz, Konsumentenverhalten oder auch Politikentscheidungen.

Die Vorgeschichte der Energiewende sowie aktuelle Debatten über ihre Zukünfte zeigen aber deutlich, dass potenzielle Transformationspfade über einen Aushandlungsprozess in Wirtschaft, Politik und Gesellschaft beschritten werden. Konzeption, Planung und Umsetzung eines solch langfristig angelegten Prozesses sind durch einen hohen Grad an Komplexität und Unsicherheit gekennzeichnet, so dass aus einer ex ante Perspektive explizit unterschiedliche Zukünfte möglich sind. Da in einer demokratisch verfassten Gesellschaft über den Diskurs allgemein 
akzeptierte oder zumindest mehrheitlich tolerierte Transformationspfade gefunden werden müssen, stellt sich für die Wissenschaft die Frage, wie relevante Informationen über mögliche Zukunftspfade generiert und in den gesellschaftlichen Diskurs eingespeist werden können.

Die Wissenschaft hat dabei die Aufgabe, Zukunftspfade der Energiewende zu identifizieren und zu charakterisieren, um Entscheidungsträger*innen in Politik, Wirtschaft und Gesellschaft sowie der Öffentlichkeit Wissen (und Nicht-Wissen) für eine erfolgversprechende Transformation an die Hand zu geben. Die Komplexität der Aufgabe bedarf der Integration unterschiedlicher Perspektiven, Disziplinen und Vorgehensweisen, aus denen wir für dieses TATuP-Thema insbesondere drei Herausforderungen aufgreifen:

1. Wissen über Energiezukünfte: Als soziotechnisches System mit einem hohen Grad an Komplexität, Unsicherheit und Ambivalenz zeichnet sich das Energiesystem durch eine Vielzahl von möglichen gesellschaftspolitischen und techno-ökonomischen Zukunftspfaden aus, die nicht zwingend kompatibel zueinander sind. Dabei stellen sich interdisziplinäre Herausforderungen, wie Transformationspfade methodisch und inhaltlich identifiziert, charakterisiert und gegeneinander $a b-$ gegrenzt werden können.

2. Beratung über Energiezukünfte: Den unweigerlich offenen, mehrgleisigen und nur bedingt vorhersagbaren Charakter von soziotechnischen Energiezukünften behandelt die Wissenschaft u. a. mit den Begriffen Kontingenz, Unsicherheit und Nicht-Wissen. Damit bewegen sich wissenschaftliche Zukunftsaussagen zur Beratung über Energiezukünfte im sierungen sowie erfolgversprechende Umsetzungsvorschläge. Damit stellt sich die Herausforderung, wie wissenschaftliche Expertise bestmöglich an Entscheidungsträger*innen und Öffentlichkeit übermittelt wird.

Die Beiträge in diesem Schwerpunkt bewegen sich mit jeweils unterschiedlichen Akzentuierungen an diesen Schnittstellen von Wissen, Beratung und Gestaltung für wissenschaftliche Energiezukünfte.

\section{Beiträge in diesem TATuP-Thema}

Um den Herausforderungen gerecht zu werden, die sich aus dem notwendigen oder auch nur gewünschten Wissen über Energiezukünfte ergeben, entwickeln die ersten beiden Beiträge Vorschläge zur interdisziplinären Berücksichtigung von unterschiedlichen methodischen Zugängen.

Dirk Scheer und Lisa Nabitz öffnen den Fokus auf Energiezukünfte mit einer Gegenüberstellung des soziotechnischen Energiesystems als Forschungsgegenstand mit vorhandenen methodischen Ansätzen von Zukunftswissen. Mit einem Plädoyer für eine systemische Energiezukünfteforschung sprechen sie sich für eine explizit interdisziplinäre Weiterentwicklung aus, die sequentielle und komplementäre Kombinationen von techno-ökonomischen und sozialwissenschaftlichen Theorien und Methoden berücksichtigt.

Die Komplexität soziotechnischer Systeme mit vielfach nichtlinearen Zusammenhängen ist Ausgangspunkt des Beitrags von Stefan Vögele, Witold-Roger Poganietz und Philip Mayer. Mit dem Ansatz der Cross-Impact-Balance (CIB)-Methode schlagen

\section{Wissenschaft hat die Aufgabe, Zukunftspfade der Energiewende zu identifizieren und zu charakterisieren, um Entscheidungsträger*innen Wissen (und Nicht-Wissen) an die Hand zu geben.}

Spannungsfeld zwischen möglichst validen und hochgradig unsicheren Aussagen. Vor diesem Hintergrund liegen zentrale Herausforderungen der Reflexion insbesondere in methodischen und inhaltlichen Weiterentwicklungen, die Aspekte wie Sicherheit und Unsicherheit sowie Wissen und NichtWissen identifizieren, beforschen und Wege aufzeigen diese zu kommunizieren.

3. Gestaltung von Energiezukünften: Akteure der Transformationsgestaltung sind auf wissenschaftliche Untersuchungen und Umsetzungshilfen für diese hochkomplexen und zum Teil auf verschiedenen Ebenen parallel verlaufenden Veränderungsprozesse angewiesen. (Politische) Entscheidungsträger*innen brauchen und fordern von der Wissenschaft Gestaltungshilfen über zukünftige Handlungsoptionen, Priori- sie eine Methodeninnovation vor, die eine realitätsnähere Betrachtung von nicht-linearen Zusammenhänge in quantitativen Energieszenarien ermöglicht. Dadurch sollen wissenschaftliche Energieszenarien näher an soziotechnische Wirkungszusammenhänge herangeführt werden.

Die Validität von Zukunftsaussagen ist ein kritischer Punkt in der Beratung über Energiezukünfte. Die folgenden drei Beiträge thematisieren dies hinsichtlich einer besseren Berücksichtigung von gesellschaftlichen Vorstellungen, Technikdiffusion sowie Technikakzeptabilität.

Vorschläge zur methodischen Integration von unterschiedlichen Positionen von Stakeholdern in die Erarbeitung von Energiezukünften stehen im Mittelpunkt des Beitrags von Ricarda Schmidt-Scheele, Dierk Bauknecht, Witold-Roger Poganietz, 
Dominik Seebach, Christof Timpe, Wolfgang Weimer-Jehle und Annika Weiss. Die Zielorientierung eines klimaverträglichen Energiesystems setzt gesellschaftliche Vorstellungen und Visionen über dessen Umbau voraus. Diese Vorstellungen müssen bei der Erarbeitung von Energiezukünften als intentionales Handeln Berücksichtigung finden. Über die methodischen Ansätze von Leitmotiven und partizipativer Storylineentwicklung werden die Vorschläge konkretisiert.

Der Diffusion nachhaltiger Technologien kommt bei der Transformation des Energiesystems eine zentrale Bedeutung $\mathrm{zu}$, zugleich ist sie aufgrund vielfältiger Einflussvariablen als Zukunftsaussage schwer abschätzbar. Der Beitrag von Joachim Globisch, Bert Droste-Franke, Gabriele Fohr und Sandra Wassermann thematisiert einen Ansatz, wie sich die Robustheit von Zukunftsaussagen zur Technikdiffusion verbessern lässt. Der Ansatz fokussiert vor dem Hintergrund der Heuristik des Technologischen Innovationssystems (TIS) auf eine Kombination von empirischen, sozialwissenschaftlichen Daten mit einer innovationsbezogenen, agentenbasierten Modellierung (ABM). Im Kern geht es um Vorschläge, wie verschiedene qualitative und quantitative Datenquellen zur Validierung und Kalibrierung eines ABM-Modells genutzt werden können.

Julia Epp und Theresa Pfaff nehmen in ihrem Beitrag die Akzeptabilität von neuen Technologien für Energiezukünfte in den Blick. Als Beispiel dienen die derzeit intensiv diskutierten Power-to-X-Technologien (P2X), bei denen mithilfe von (überschüssigem) Strom Energie gespeichert bzw. für anderen Nutzungsarten umgewandelt werden kann. Anhand sozialer und ökologischer Akzeptabilitätskriterien werden unterschiedliche P2X-Szenarien diskutiert.

Die beiden letzten Beiträge thematisieren die Gestaltung von Energiezukünften. Zum einen werden energierechtliche Interventionen als staatliche Gestaltungsoptionen betrachtet. Zum anderen werden Alltagspraktiken in den Blick genommen, an denen sich eine erfolgreich gestaltete Energiewende letztlich beweisen muss.

Herausforderungen von Energiezukünften aus rechtswissenschaftlicher Perspektive stehen im Mittelpunkt des Beitrags von Michael Kalis und Lars Dittmar. Die Ausgestaltung der Energiewende obliegt zuvorderst staatlicher Rahmensetzungen. Dabei kommt dem Energiewenderecht eine zentrale Bedeutung zu, sind doch rechtliche Machbarkeit und Steuerungsfähigkeit entscheidende Stellgrößen für eine erfolgreiche Transformation. Vor diesem Hintergrund analysieren die Autoren sogenannte Experimentierklauseln, Sonderförderregionen und eine $\mathrm{CO}_{2}-\mathrm{Be}-$ preisung als rechtliche Transformationsinstrumente.

Schließlich greifen Uta Böhm, Martina Schäfer und Maria Stadler das Handlungsfeld Energieeffizienz im Spannungsfeld zwischen Anlagentechnik und sozialen Akteuren auf. Die Transformation des Energiesystems wird sich letztlich in adäquaten Alltagspraktiken entscheiden. Am Beispiel des energieeffizienten Betriebs von Heizungsanlagen zeigen die Autorinnen, dass die prognostizierten Einsparungen in der Praxis meist nicht erreicht werden. Aus soziotechnischer Perspektive wird deutlich, dass insbesondere arbeitsorganisatorische Aspekte als Hemmschuh fungieren.

\section{Literatur}

BMU - Bundesministerium für Umwelt, Naturschutz und nukleare Sicherheit (2016): Klimaschutzplan 2050. Klimaschutzpolitische Grundsätze und Ziele der Bundesregierung. Online verfügbar unter http://www.bmu.de/fileadmin/ Daten_BMU/Download_PDF/Klimaschutz/Klimaschutzplan_2050_bf.pdf, zuletzt geprüft am 25.10.2019.

Grunwald, Armin (2011): Energy futures. Diversity and the need for assessment. In: Futures 43 (8), S. 820-830.

Meadowcroft, James (2009): What about the politics? Sustainable development, transition management, and long term energy transitions. In: Policy sciences, 42 (4), S. 323-340.

Scheer, Dirk; Konrad, Wilfried; Renn, Ortwin; Scheel, Oliver (2014): Energiepolitik unter Strom. Alternativen der Stromerzeugung im Akzeptanztest. München: oekom.

Schippl, Jens; Grunwald, Armin; Renn, Ortwin (Hg.) (2017): Die Energiewende verstehen - orientieren - gestalten. Baden-Baden: Nomos.

Schippl, Jens; Grunwald, Armin (Hg.) (2013): Energiewende 2.0. Vom technischen zum soziotechnischen System? In: TATuP - Zeitschrift für Technikfolgenabschätzung in Theorie und Praxis 22 (2), S. 4-62.

Smil, Vaclav (2010): Energy transitions. History, requirements, prospects. Santa Barbara: Praeger/ABC CLIO.

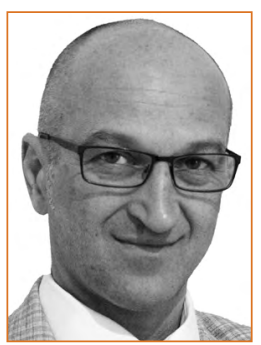

\author{
DR. DIRK SCHEER \\ ist wissenschaftlicher Mitarbeiter am ITAS/KIT \\ Seine Forschungsschwerpunkte sind sozialwissen- \\ schaftliche Energieforschung, Technologieakzeptanz, \\ Wissenstransfer und -management (science- \\ policy interface) sowie Partizipations- und Risiko- \\ forschung.
}

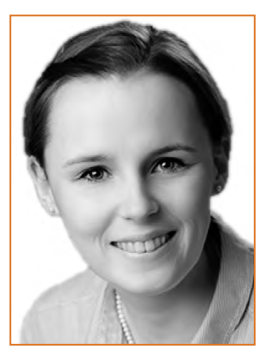

\section{LISA NABITZ}

ist wissenschaftliche Mitarbeiterin am ITAS/KIT. In ihren Arbeiten befasst sie sich mit sozialwissenschaftlicher Forschung zur Transformation des Energiesystems, derzeit u. a. zu Fragen der MultiLevel-Governance im Mobilitätssektor sowie zum gegenwärtigen Zukunftsdiskurs von synthetischen Kraftstoffen.

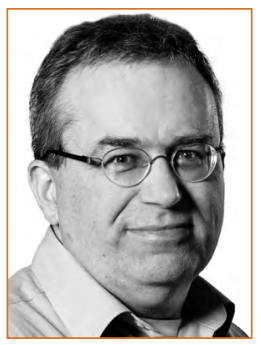

\section{DR. WITOLD-ROGER POGANIETZ}

ist wissenschaftlicher Mitarbeiter am ITAS/KIT. Sein Forschungsschwerpunkt liegt in der Analyse von soziotechnischen Treibern und Hemmnissen bei der Transformation von Energiesystemen in Europa und im „Globalen Süden“. 


\title{
Klimaverträgliche Energiezukünfte (nicht) wissen
}

\author{
Dirk Scheer, Institut für Technikfolgenabschätzung und Systemanalyse (ITAS), Karlsruher Institut für Technologie (KIT), \\ Karlstraße 11, 76133 Karlsruhe (dirk.scheer@kit.edu), D orcid.org/0000-0002-7472-8331 \\ Lisa Nabitz, Institut für Technikfolgenabschätzung und Systemanalyse (ITAS),Karlsruher Institut für Technologie (KIT) (lisa.nabitz@kit.edu)
}

Die Energiewende in Deutschland illustriert wie kaum ein anderes Vorhaben Möglichkeiten und Grenzen wissenschaftlichen Zukunftswissens. Vor allem in Wissenschaft und Politik werden Energiezukünfte seit geraumer Zeit entwickelt und diskutiert. Einerseits sollen so mit wissenschaftlicher Fundierung mögliche, rationale, wahrscheinliche, optimierte und/oder sozialverträgliche Wege für ein klimaverträgliches Energiesystem aufgezeigt werden. Andererseits soll das Wissen um unterschiedliche Entwicklungspfade bei Entscheidungsträger*innen als Handreichung und Orientierung für die Konkretisierung und Ausgestaltung der Energiewende dienen. Dieser Beitrag reflektiert über Potenziale und Grenzen der unterschiedlichen wissenschaftlichen Ansätze von Energiezukünften im Lichte soziotechnischer Energiesysteme.

\section{(Not) knowing climate-friendly energy futures}

The energy transition in Germany concisely illustrates opportunities and limitations of scientific future knowledge. Energy futures are developed and elaborated primarily in science and politics: On the one hand, science aims at providing possible, rational, probable, optimized, and/or socially acceptable pathways and options for a climate-friendly energy system. On the other hand, policy makers need support and advice for deciding on and implementing the energy transition process. This contribution reflects on potentials and challenges of several scientific energy future concepts against the characteristics of socio-technical energy systems.

Keywords: climate-friendly energy transition, future knowledge, socio-technical system

\section{Einführung}

Die Energiewende in Deutschland illustriert wie kaum ein anderes Vorhaben Möglichkeiten und Grenzen wissenschaftlichen Zukunftswissens. Mit dem Ziel der Politikberatung werden vor allem in der Wissenschaft und angrenzenden Bereichen Szenarien und Visionen mittels unterschiedlicher Methoden ent-

This is an article distributed under the terms of the Creative Commons Attribution License CCBY 4.0 (https://creativecommons.org/licenses/by/4.0/)

https://doi.org/10.14512/tatup.28.3.14

Submitted: 05. 07.2019. Peer reviewed. Accepted: 24.10.2019 wickelt. Dadurch sollen wissenschaftlich fundiert mögliche, rationale, wahrscheinliche, optimierte und/oder sozialverträgliche Wege für ein klimaverträgliches Energiesystem aufgezeigt werden, um Entscheidungsträger*innen als Handreichung und Orientierung für die Konkretisierung und Ausgestaltung der Transformation des Energiesystems zu dienen (Scheer 2013). Diese Energiezukünfte zeigen die Offenheit und Bandbreite eines avisierten Energiesystemumbaus. Dieser Beitrag reflektiert über Potenziale und Grenzen von wissenschaftlich fundierten Energiezukünften. Dabei wird das Energiesystem als soziotechnischer Forschungsgegenstand unterschiedlichen methodischen Ansätzen von Energiezukünften gegenübergestellt. Vor diesem Hintergrund plädieren wir für eine systemische Energiezukünfteforschung unter Einbezug interdisziplinärer Ansätze zum besseren Verständnis von Randbedingungen, Wirkungszusammenhängen und daraus abgeleiteter Erklärung bzw. Prognose (Hempel und Oppenheim 1948). Die Integration unterschiedlicher Ansätze soll dabei helfen, spezifische Randbedingungen und Wirkungszusammenhänge besser zu verstehen und wissenschaftlichen $\mathrm{Zu}$ kunftsaussagen zugrunde zu legen.

\section{Das Energiesystem als komplexes soziotechnisches System}

Das Energiesystem als hochgradig verschränktes, soziotechnisches System mit sektorspezifischen und -übergreifenden Systemeigenheiten und -rationalitäten aufzufassen, gewinnt zunehmend Anerkennung (Elzen et al. 2004; Büscher und Schippl 2013). Entlang der Bereitstellung, Verteilung und Nutzung von Energie in den Sektoren Strom, Wärme und Mobilität sind technische Komponenten mit sozialen Akteuren und ihren individuellen und kollektiven Entscheidungen eng verknüpft. Damit treffen technische, institutionelle, ökonomische und soziale Parameter aufeinander und sind über Wechselwirkungen miteinander verbunden. Das Energiesystem, wie es sich heute oder zukünftig (gewünscht) darstellt, ist damit eine Ausprägung dieses Zusammenspiels und zeichnet sich durch einen hohen Grad an Komplexität aus. Dabei ist es für das Wissen um Energiezukünfte herausfordernd, die genaue Ausgangskonfiguration (Randbedingungen) und die Wechselwirkungen der Einflussfaktoren (Wir- 
kungszusammenhänge) intersubjektiv zu bestimmen. Die Komplexitätsunterschiede im Energiesystem werden im Folgenden über eine Sektorenbetrachtung kurz skizziert.

Der bislang erfolgreichste Sektor mit Blick auf die Transformation - der Stromsektor - gilt als verhältnismäßig moderat komplex. Die hemmenden strukturellen Herausforderungen zu Beginn des Umbaus um die Jahrtausendwende wurden als überschaubar eingestuft, gekennzeichnet durch „Leitungsbindung, Oligopole, Fehlallokationen und auf Beharrung, nicht Innovation setzende Rahmenbedingungen“ (Hesse 2018, S. 17). Zugleich stellt sich die Technikkonfiguration in Verbindung mit sozialer Praxis von Strombereitstellung, Infrastruktur und Nutzung recht „,wendegünstig“ dar. Mit dem Fokus auf einen klimaverträglichen Umbau des Strommixes von fossilen auf erneuerbare Stromtechnologien (Wind, Photovoltaik, Biomasse) stand vor allem die Strombereitstellung im Fokus der Transformation, ergänzt um den Aspekt von kurz- und langfristigen Stromspeicherungsoptionen. Weitreichende, radikale Änderungen bei der Infrastruktur sind für die Stromwende im Vergleich mit den anderen beiden Sektoren nicht notwendig. Hier stehen allenfalls inkrementelle Änderungen einer digitalen Ertüchtigung des Netzes oder aber eine deutliche, investitionsintensive Netzerweiterung über den Netzausbau für die Offshore-Anbindung auf der Transformationsagenda. Die Nutzungsphase in Haushalten und Industrie ist hingegen wenig von notwendigen strukturellen Änderungen betroffen. Vielmehr geht es nachfrageseitig darum, bestehende Hemmnisse für ein energieeffizientes Verhalten abzubauen (Böhm et al. 2019 in diesem Heft). Im Vordergrund der Stromwende stehen damit eher institutionelle und gesellschaftliche Faktoren beim weiteren Ausbau von Erneuerbaren Energien. Darunter fallen Aspekte der politischen Rationalität, wie bspw. gesellschaftliche Partizipation und Vertrauen in Planungs- und Entscheidungsprozessen, Verteilungswirkungen von Maßnahmen in der Energiepolitik und politische sowie rechtliche (Kalis und Dittmar 2019 in diesem Heft) und verhaltensorientierte Barrieren.

Im Wärmesektor sind dagegen grundlegendere Transformationen notwendig. Hier reicht eine Substitution des Energieträgers mit Beibehaltung der etablierten Infrastrukturen sowie Endnutzungsgeräten nicht aus, da die Technikketten über den gesamten Sektor u. a. auf die fossilen Energieträger Öl und Gas ausgerichtet sind. Die avisierte Wärmewende über Strategien der Effizienz sowie der direkten und indirekten Elektrifizierung bedarf eines grundlegenderen Umbaus - gerade auch auf der Verbraucherseite. Gefragt sind Neuinvestitionen in Wärmenetze, Wärmepumpen in Neu- und Altbauten sowie eine höhere Gebäudesanierungsrate und -tiefe.

Auf Nutzungs- wie auch auf Anbieterseite treten jedoch transformationshemmende Strukturmerkmale auf (Wesche et al. 2019), z. B. das sogenannte Nutzer-Investor- bzw. Mieter-Vermieter-Dilemma (Ástmarsson et al. 2013): Während Mieter*innen die Kosten von Energieverbräuchen tragen, haben sie kaum Einfluss auf Investitionen im Gebäudebereich. Ihnen bleibt alleine der Weg über Energieverbrauchseinsparungen. Für Vermieter*innen ist der Anreiz in Neuinvestitionen dagegen eher gering, da sie ökonomisch nicht von verbrauchsbedingten Effizienzsteigerungen profitieren. Dem/der Mieter*in ohne Einfluss steht der/die Vermieter*in ohne Anreiz gegenüber. Als weitere Hemmnisse (FVEE 2016) gelten hohe Technologiekosten für den Einsatz klimafreundlicher Wärmetechnik sowie geringe Transparenz und Bekanntheit von marktverfügbaren Produkten.

Der Verkehrssektor hingehen weist im Sektorenvergleich eine deutlich höhere Komplexität auf. Trotz aller politischen Ziele ist es bislang nicht gelungen, die Treibhausgasemissionen des Verkehrs unter das Niveau des Jahres 1990 zu senken, im Gegenteil: Die Emissionen steigen kontinuierlich an - auch wenn 2018 ein leichter Rückgang zu konstatieren ist (BMU 2019). Wirtschaftliche Verflechtungen in stark spezialisierten Wertschöpfungsketten mit entsprechendem Bedarf an hochqualifizierten, mobil einsetzbaren Arbeitskräften einerseits sowie Mobilität als Ausdruck von Freiheit, Individualität und Unabhängigkeit andererseits eröffnen das Spannungsfeld, in dem sich Diskussionen über die „Verkehrswende“ entzünden. Kurz: „Verkehr näht zusammen, was in zunehmend spezialisierten und fragmentierten gesellschaftlichen Teilsystemen raumzeitlich auseinander fällt" (Hesse 2018, S. 17). Dabei sind mit der Verkehrswende mehrere Zielsetzungen verknüpft, die ein wesentlich breiteres Themenspektrum als nur den Klimaschutz umfassen. Im direkten Umfeld geht es um eine Erhöhung der Lebensqualität durch Senkung der Luftschadstoff- und Lärmbelastung ebenso wie durch eine stärker mensch- als autofokussierte Gestaltung von Straßen, Quartieren und Städten, aber auch um Zeitersparnis durch eine Entlastung der Infrastrukturen und Stauvermeidung. Gleichzeitig sollen die Mobilitätbedürfnisse des Einzelnen in gleichem Maße befriedigt werden können und der heute erreichte Mobilitätsgrad mindestens erhalten, wenn nicht sogar weiter erhöht werden, denn Mobilität wird mit individueller Freiheit gleichgesetzt und diese soll keinesfalls beschnitten werden.

\section{Vier Herausforderungen des (Nicht-)Wissens von Energiezukünften}

(Politische) Entscheidungen über Energiezukünfte müssen trotz aller Komplexität des soziotechnischen Energiesystems, möglicher Pfadabhängigkeiten und Unsicherheiten sowie Nicht-Wissens über intendierte und nicht-intendierte wirtschaftliche, ökologische und gesellschaftliche Folgen dieser Entscheidungen getroffen werden. Die Genese von wissenschaftlichem System-, Orientierungs- und Handlungswissen für Energiezukünfte spielt dabei als Inputgeber für Randbedingungen und Wirkungsketten eine zentrale Rolle und ist analytisch und methodisch mit Herausforderungen konfrontiert.

\section{Soziotechnische Wirkungszusammenhänge besser verstehen}

Eine zentrale Herausforderung besteht darin, die sektorspezifischen und -übergreifenden Einflussfaktoren adäquat zu erfassen sowie ihr Zusammenspiel über die Bereiche Technik, Orga- 
nisation, Verhalten und politische Steuerung zu verstehen. Dabei muss auch zugrunde gelegt werden, dass die Wirkungszusammenhänge kontextabhängig variieren und nicht über die Zeit konstant sind: Unter anderem sind ökonomische, habituelle, wertbasierte oder institutionelle Rationalitäten für Entscheidungsträger*innen und (Energie)Verbraucher*innen relevant. Während bspw. die energieintensive Industrie sehr sensitiv auf Preissignale reagiert, fallen Entscheidungen im Mobilitätssektor je nach Rahmenbedingungen und Präferenzen unterschiedlich aus. So liegt die Hypothese nahe, dass die Kaufentscheidung für ein SUV vornehmlich nach nichtökonomischen Kriterien getroffen wird. Um diese Wirkungszusammenhänge besser herauszuarbeiten und zu verstehen, ist eine stärkere Integration von unterschiedlichen Ansätzen von Zukunftswissen vielversprechend. Dabei ist wichtig, sektorspezifisch die treibenden Faktoren - wie bspw. verschiedene Preiselastizitäten, den Einfluss persönlicher Grundüberzeugungen o. Ä. - und ihre Wirkungsmechanismen herauszuarbeiten. Die Verknüpfung der Annahmen zu Entscheidungsrationalitäten mit der Heuristik der Lebensstile (z. B. Sinus-Milieus) kann dabei ein wichtiger Ansatzpunkt sein, um Varianzen beim Entscheidungsverhalten besser zu erfassen. Ex-post Analysen einer kausalen Rekonstruktion helfen dabei, das Zusammenspiel von Einflussfaktoren soziotechnischer Systeme eingehender zu analysieren und als Ausgangsbedingung den Szenarien und Visionen von Energiezukünften zugrunde zu legen. Ein methodischer Ansatz zur Berücksichtigung nicht-linearer Wirkungsketten wird im Beitrag von Voegele et al. 2019 (in diesem Heft) über die Methode der Cross-Impact-Balance vorgestellt. Globisch et al. 2019 (in diesem Heft) unternehmen konzeptionelle Überlegungen mit Blick auf eine Verknüpfung von innovationstheoretischen Ansätzen mit agentenbasierter Modellierung.

\section{Die (Ir-)Relevanz von Gegenwartsdiskursen}

In Energiezukünften hat der gegenwartsbezogene Diskurs oftmals eine große Bedeutung. Einerseits bestimmen Gegenwartsdiskurse substantiell die Ausrichtung von Energieszenarien. Andererseits sind Vergangenheitsdiskurse (und die sich aus ihnen ergebenden Energiezukünfte) heute nicht mehr zeitgemäß und gelten als überholt. Vor etwa fünf Jahren gab es bspw. eine intensive Diskussion über eine $\mathrm{CO}_{2}$-Sequestrierung oder die Desertec-Initiative. Als Folge waren viele Energieszenarien CCS- und/ oder Desertec-basiert - mit aus heutiger Sicht nur noch wenig Relevanz. Gegenwartsdiskurse über Technikpotenziale, Akzeptanzniveaus oder politische Rahmenbedingungen haben folglich entscheidenden Einfluss auf die inhaltliche Ausrichtung von Energiezukünften. Dabei stellt sich die Frage: Wie beständig oder wie gegenwartsbezogen sind Energiezukünfte? Dieser Herausforderung sollte mit einer sequenziellen Revision, dem kontinuierlichen Blick in die Vergangenheit und der Integration von lessons learned in zukünftigen Szenarien begegnet werden, die das diskursive und konstruktive Element von Technik- und $\mathrm{Zu}$ kunftsdebatten auch in die Erarbeitung von wissenschaftlichen Energiezukünften integrieren. Der Beitrag von Epp et al. 2019 (in diesem Heft) ist ein gutes Beispiel, wie eine gegenwärtige
Betrachtung von Akzeptabilität und Wünschbarkeit bei Power-to-X-Technologien die Bedeutung von Energiezukünften beeinflussen. Einen methodischen Beitrag zur Berücksichtigung von Gegenwartsdiskursen über die systematische Erfassung von Stakeholder-Perspektiven liefern Schmidt-Scheele et al. 2019 (in diesem Heft).

\section{Transformation als Disruption zwischen Pfadabhängigkeit und Pfadänderung}

Pfadfortschreibung oder Pfadänderung sind wesentliche Elemente in der Analyse von Zukünften. Das Entstehen von Pfadabhängigkeiten im Transformationsprozess ist dabei unvermeidbar. Pfadabhängigkeiten entstehen, wenn sich im Zeitverlauf nur noch ein Pfad herauskristallisiert und keine Pfadänderung mehr vorgenommen wird (Fischedick und Grunwald 2017). Pfadabhängigkeiten können zum einen aufgrund bestimmter vergangener Entwicklungen und Entscheidungen entstehen, wie bspw. durch den Bau einer autogerechten Stadt. Zum anderen können sie durch bewusste Handlungen relevanter Akteure induziert werden, z. B. durch geänderte Erwartungshaltungen oder Netzwerkeffekte. Historizität ist somit Wesensmerkmal von Energiesystemen. Insofern liegt eine weitere Herausforderung im Zuge der Reflektion über Energiezukünfte in der Berücksichtigung von Pfadabhängigkeiten bei langfristigen Entscheidungen, wie bspw. bei Transformationsprozessen im Bereich der urbanen Mobilität, des Güterverkehrs oder auch des Netzausbaus und der Sektorkopplung.

\section{Interventionen als sine qua non für zielgerichtete Transformation}

Interventionen spielen mit Blick auf das Auslösen von Transformationspfaden eine zentrale Rolle. Spätestens seit der Förderung der erneuerbaren Energien in den 1990er- und 2000er-Jahren sowie sodann verstärkt seit der Veröffentlichung des Energiekonzepts durch die Bundesregierung im Jahr 2010 (BMWi und BMU 2010) wurden zahlreiche unterschiedliche Instrumente in den Sektoren Strom, Wärme und Mobilität auf unterschiedlichen Systemebenen implementiert, die allesamt das Ziel verfolgen, die verschiedenen ökonomischen, technischen, juristischen und informatorischen Hemmnisse für das Gelingen der Energiewende zu überwinden. Die erhöhte Komplexität des Rechtsrahmens, die Verknüpfung verschiedener Governance-Ebenen (Kommune/Stadt, Land, Bund, EU und international) sowie das stetige Anwachsen der Anzahl politischer Instrumente (Kalis und Dittmar 2019 in diesem Heft) stellen eine besondere Herausforderung für die Erarbeitung von Energiezukünften dar. Methodisch stellt sich insbesondere die Frage, wie das Design und die Wirkung von Instrumenten sowie deren Interaktion (sowohl sektorspezifisch als auch -übergreifend) adäquat adressiert werden können, um basierend darauf politische Entscheidungen treffen zu können. Daneben besteht die Herausforderung gleichermaßen darin, die Abschaffung von bestehenden sowie die Einführung von neuen Politikinstrumenten in Energiezukünften systematisch abzubilden. 


\section{Prognose- und erklärungsbasierte Ansätze zur Herleitung soziotechnischer Energiezukünfte}

a. vorhersageorientiert

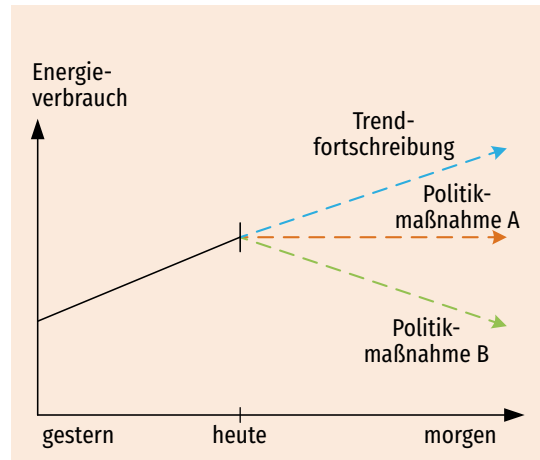

b. explorativ

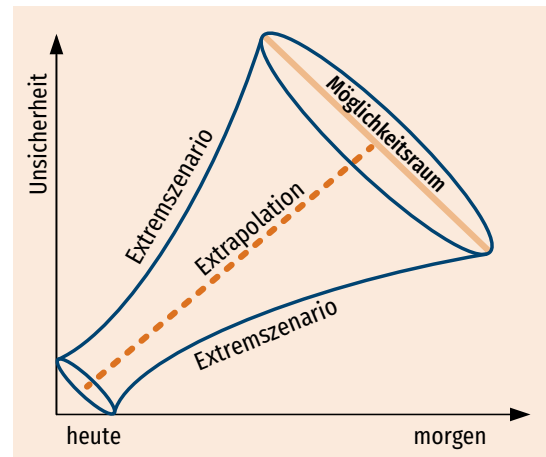

\section{c. normativ}

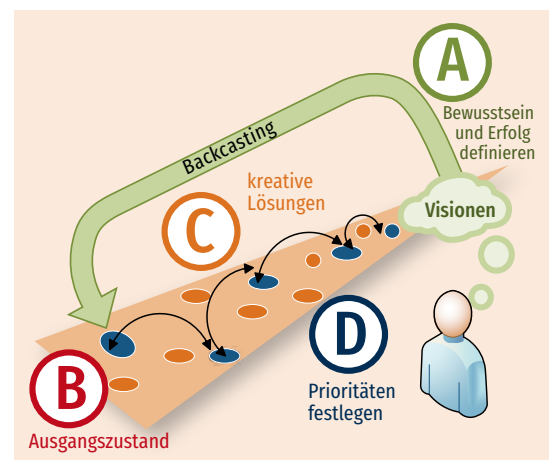

d. Multi-Level-Perspective

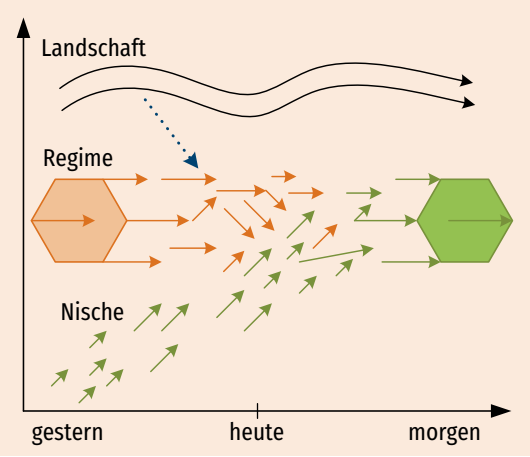

\section{e. Sociotechnical imaginaries}

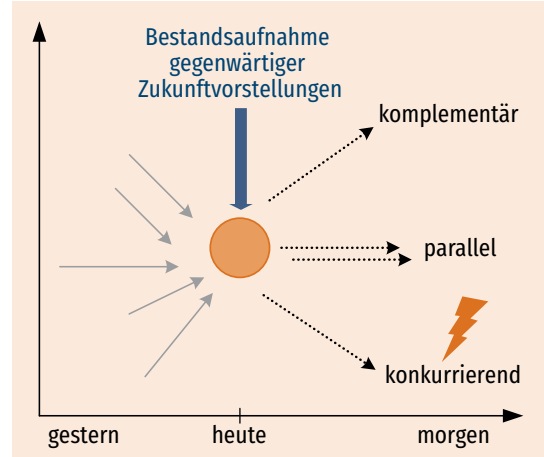

Abb.1: Methoden soziotechnischer Energiezukünfte.

\section{Exemplarische Methoden für Energie- zukünfte}

Epistemisches Ziel von Methoden für Energiezukünfte ist es, auf Plausibilität und Konsistenz beruhende Zukunftsentwürfe des Energiesystems zu entwickeln. Wir greifen im Folgenden exemplarisch fünf unterschiedliche Ansätze für Energiezukünfte heraus und erläutern kurz deren Spezifika. Abbildung 1 visualisiert die Spezifika dieser prognose- und erklärungsbasierten Ansätze zur Herleitung soziotechnischer Energiezukünfte.

Ein erster Ansatz und von großer Bedeutung sind systemanalytische, oftmals computerbasierte Energieszenarien (Börjeson et al. 2006; Nursimulu 2015). Diese lassen sich unterscheiden in vorhersageorientierte, explorative und normative $\mathrm{Zu}$ kunftsstudien (Nursimulu 2015). Vorhersageorientierte Ansätze sind in der Regel computerbasierte Simulationsrechnungen mit einem quantitativen Design. Verschiedene Aspekte von prognoseorientierten, quantitativen Energieszenarien wurden herausgestellt: Es können top-down (makroökononische), bottom-up
Quelle: Eigene und erweiterte Darstellung in Anlehnung an Nursimulu 2015 (techno-ökonomische oder ingenieurwissenschaftliche) oder hybride Modellierungen differenziert werden. Diese unterscheiden sich u. a. nach der Fokussierung auf ein ökonomisches Gleichgewicht (partiell oder generell), Optimierung (Minimierung/ Maximierung von Variablen wie Kosten, Nachhaltigkeitsmetrik, Wohlfahrt, Gewinn), Input-Output-Modelle, ökonometrische oder Multi-Agenten-Modelle (Herbst et al. 2012), die keine bzw. stark vereinfachte Verhaltensannahmen für Akteure unterstellen. Über einen Algorithmus, indem die Wirkungsbeziehungen hinterlegt sind, werden zukünftige Systemausprägungen „errechnet“. Auf Basis einer extrapolierten Trendfortschreibung über historische Daten werden Prognosen unter plausiblen Annahmen von Randbedingungen, wie etwa bestimmte Politikentscheidungen, geliefert. Explorative Ansätze sind oftmals quantitativ, können aber auch ein qualitatives Design zugrunde legen. Auch diese Ansätze basieren auf plausiblen Trendfortschreibungen, legen allerdings einen deutlichen Fokus auf sudden events also Ereignisse, die zu disruptiven Entwicklungen führen können, die dann fortgeschrieben werden. Normative Szenarien im 
Sinne von Zielszenarien nehmen im Vergleich eine entgegengesetzte Perspektive ein, indem sie die Zukunftsausprägung nach bestimmten normativen Zielsetzungen zugrunde legen, um dann ,rückwärts‘ den Weg zur Gegenwart zu ,berechnen`.

Ein weiterer, in den Sozialwissenschaften entwickelter Ansatz firmiert unter Multi-Level-Perspective (Rip und Kemp 1998; Geels 2002) und ist der Innovations- und Transformationsforschung zuzuordnen. Die Multi-Level-Perspektive fokussiert auf das Zusammenspiel und die Verflechtung von technologischen, ökonomischen, politischen und kulturellen Variablen. Grundannahme ist, dass die entscheidenden Einflussvariablen in realweltlichen soziotechnischen Systemen schwierig zu identifizieren und ihre Wirkungszusammenhänge - weil variabel bestenfalls über Einzelfallbetrachtungen ex-post zu eruieren sind. Verallgemeinerbare Aussagen der Wirkungsbeziehungen im Sinne von Gesetzmäßigkeiten lassen sich daraus in der Regel nicht ableiten. Auf dieser Grundannahme wurde ein konzeptionell-heuristisches Modell entwickelt, das grundlegende Transformationen über (radikale) Innovationen erklärt. Diese für Pfadänderungen entscheidenden Innovationen werden über eine Mehrebenen-Perspektive aus Nische, Regime und Landschaft betrachtet. Zunächst entwickeln sich Innovationen auf der Ebene der Nische, gestützt durch wenige individuelle oder kollektive Akteure. Die Ebene der Nische ist dabei weitgehend außer Sichtweite der allgemeinen Wahrnehmung. Diese Nischenentwicklungen stehen im Zusammenhang (komplementär oder kompetitiv) mit der zweiten Ebene, des sogenannten Regimes. Beim Regime handelt es sich um etablierte Strukturen von Akteurskonstellationen mit institutionellen Settings, welche bestimmte Regeln, Konventionen sowie ökonomische, technische, etc. Strukturen inkorporiert haben. Auf der dritten Ebene der sogenannten Landschaft - wirken übergeordnete Dynamiken wie bspw. Demographie oder Digitalisierung, die das Regime dauerhaft beeinflussen. Auch sudden events in der Landschaft, wie beispielsweise die Nuklearkatastrophe von Fukushima, beeinflussen das System. Im Zuge der Wechselwirkung von Nische, Regime und Landschaft kommt es zu Selektions-, Kanalisierungs- und Verfestigungsprozessen, bei denen unter günstigen Bedingungen eines windows of opportunity Nischeninnovationen das Regime herausfordern und langfristig ,übernehmen“, so dass Pfadänderungen mit der Etablierung neuer Transformationspfade eingeleitet werden.

Der Ansatz des Sociotechnical Imaginery geht auf Jasanoff und Kim (2009) zurück und ist dem Bereich Science and Technology Studies zuzuordnen. Zentral ist dabei die strukturelle Bedeutung der menschlichen Fähigkeit für Imagination als konstitutives, gestalterisches Element zukünftiger Entwicklungen. Der kulturelle Faktor von kollektiver Imagination wird damit zu einem bedeutenden Faktor für nicht nur mögliche, sondern auch wahrscheinliche Zukünfte. Versprechen, Visionen und Erwartungen an mögliche Zukünfte sind dabei eingebettet in Praktiken und die Organisation von Wissenschaft; deren Akteure formen so Zukunftswege im Bereich Forschung und Innovation. Dabei imaginieren sie auch implizit eine konkrete Vorstellung über die soziale Welt - z. B. wie Wechselwirkungen zwischen Technik, Ökonomie, Politik und Gesellschaft (zu) funktionieren (haben), wer als Öffentlichkeit zu gelten hat oder was als ein öffentliches Gut wahrzunehmen ist. Diese technisch-wissenschaftlichen Imaginationen sind dann zugleich auch soziotechnische Imaginationen, die Visionen und Vorstellungen über eine ,gute Gesellschaft“" inkorporieren. Dabei zeigen Gesellschaften parallele, teils komplementäre, teils konkurrierende Imaginationen. Ausgangspunkt der Analyse von Zukünften ist die Bestandsaufnahme von gegenwärtigen Zukunftsvorstellungen und der bereits vollzogenen Inkorporation dieser Vorstellungen in Struktur und Handlung, deren Ergebnisse ebenfalls Bestandteil von soziotechnischen Zukünften sind.

Zusammenfassend lässt sich festhalten, dass mit Blick auf Datengenese, Methodenanwendung und Ergebnisinterpretation jeder methodische Zugang spezifische Stärken und Schwächen zeigt. Eine vergleichende Charakterisierung von vorhandenen Methoden, Modellen und Interventionen ist für eine systemische Energiezukünfteforschung unabdingbare Voraussetzung. Erste Ergebnisse zu einer solchen systematischen Inventur in der Energieforschung liefern Fahl et al. (2018). Ein verstärkt integrierender Einsatz dieser Ansätze kann die Forschung zu Energiezukünften stärken.

\section{Fazit}

Die Weiterentwicklung der Energiewende und damit einhergehend stetige Änderungen in den Rahmenbedingungen erfordern umfangreiches und detailliertes Zukunftswissen, auch für Beratungsleistungen von der Wissenschaft an die Politik. Die zugleich anhaltend steigende Komplexität des Energiesystems sowie unterschiedliche Wirkungszusammenhänge und Entscheidungsrationalitäten je nach Sektor und jeweiliger Zielgruppe machen ein interdisziplinäres Befassen mit soziotechnischen Energiezukünften notwendig. Der vorliegende Beitrag reflektierte über Potenziale und Grenzen von wissenschaftlich fundierten Energiezukünften. Dabei wurde das Energiesystem als soziotechnischer Forschungsgegenstand unterschiedlichen methodischen Ansätzen von Energiezukünften gegenübergestellt. Vor diesem Hintergrund und auch mit dem Ziel, eine höhere Kohärenz, Vergleichbarkeit und Transparenz der verschiedenen methodischen Ansätze zu erreichen, plädieren wir für eine systemische Energiezukünfteforschung, die explizit interdisziplinäre Ansätze sowie eine sequenzielle und komplementäre Kombination techno-ökonomischer und sozialwissenschaftlicher Theorien und Methoden einschließt. Im Kontext der Kombinatorik dieser Methoden skizziert der Artikel verschiedene Herausforderungen, wie sektor- und personengruppenspezifische Entscheidungsrationalitäten, verschiedene Pfadabhängigkeiten, die (Ir-)Relevanz von Gegenwartsdiskursen, sowie die Rolle von Interventionen als sine qua non für eine zielgerichtete Transformation, die im Sinne eines zukünftigen Forschungsbedarfes allesamt von besonderer Relevanz für soziotechnische Ener- 
giezukünfte sind. In Fällen, in denen ein integrierter Einsatz von Forschungsmethoden nicht möglich erscheint, ist es wünschenswert, die Ergebnisse der disziplinären Einzeluntersuchungen als integrierte, interdisziplinäre Betrachtung mosaikartig zusammenzuführen. Wie eine Systematik eines solchen Mosaiks aussehen kann, ist Gegenstand zukünftiger Forschungsaktivitäten.

\section{Literatur}

Ástmarsson, Björn; Jensen, Per; Maslesa, Esmir (2013): Sustainable renovation of residential buildings and the landlord/tenant dilemma. In: Energy Policy 63, S. 355-362.

Börjeson, Lena; Höjer Mattias; Dreborg, Karl-Henrik; Ekvall, Tomas; Finnveden, Göran (2006): Scenario types and techniques: Towards a user's guide. In: Futures 38 (7), S.723-739.

Bundesministerium für Wirtschaft und Technologie (BMWi); Bundesministerium für Umwelt, Naturschutz und nukleare Sicherheit (BMU) (2010): Energiekonzept für eine umweltschonende, zuverlässige und bezahlbare Energieversorgung 28. September 2010. Online verfügbar unter https:// www.bmwi.de/Redaktion/DE/Downloads/E/energiekonzept-2010.pdf?_blob=publicationFile\&v=3, zuletzt geprüft am 17.10.2019.

Bundesministerium für Umwelt, Naturschutz und nukleare Sicherheit (BMU) (2019): Klimaschutz in Zahlen. Fakten, Trends und Impulse deutscher Klimapolitik. Online verfügbar unter https://www.bmu.de/fileadmin/Daten_BMU/ Pools/Broschueren/klimaschutz_zahlen_2019_broschuere_bf.pdf, zuletzt geprüft am 17.10.2019.

Büscher, Christian; Schippl, Jens (2013): Die Transformation der Energieversorgung. Einheit und Differenz soziotechnischer Systeme. In: TATUP - Zeitschrift für Technikfolgenabschätzung in Theorie und Praxis 22 (2), S.11-19. DOI: 10.14512/tatup.22.2.11.

Elzen, Boelie; Geels, Frank; Green, Kenneth (Hg.) (2004): System innovation and the transition to sustainability. Theory, evidence and policy. Cheltenham: Edward Elgar.

Fahl, Ulrich et al. (2018): Inventur der ENavi-Kompetenzen. Modelle, Methoden und Interventionen. Online verfügbar unter https://www.itas.kit.edu/ downloads/projekt/projekt_sche16_enavi_kurzbericht.pdf, zuletzt geprüft am 23.10.2019.

Fischedick, Manfred; Grunwald, Armin (2017): Pfadabhängigkeiten in der Energiewende. Das Beispiel Mobilität. München: acatech Schriftenreihe Energiesysteme der Zukunft. Online verfügbar unter https://www.acatech.de/ publikation/pfadabhaengigkeiten-in-der-energiewende-das-beispielmobilitaet/, zuletzt geprüft am 17.10.2019.

FVEE (ForschungsVerbund Erneuerbare Energien) (2016): Forschung für die Wärmewende. Beiträge zur FVEE-Jahrestagung 2015. Online verfügbar unter http://www.fvee.de/fileadmin/publikationen/Themenhefte/th2015/th2015. pdf, zuletzt geprüft am 23.10.2019.

Geels, Frank (2002): Technological transitions as evolutionary reconfiguration processes. A multi-level perspective and a case study. In: Research Policy 31, S. 1257-1274.

Hempel, Carl; Oppenheim, Paul (1948): Studies in the logic of explanation. In: Philosophy of Science 15 (2), S. 135-175.

Herbst, Andrea; Toro, Felipe; Reitze, Felix; Jochem, Eberhard (2012): Introduction to energy systems modelling. In: Swiss journal of economics and statistics 148 (2), S. 111-135. DOI: 10.1007/BF03399363.

Hesse, Markus (2018): Ein Rückblick auf die Zukunft. 25 Jahre Verkehrswende. In: Ökologisches Wirtschaften 33 (2), S. 16-18.

Nursimulu, Anjali (2015): Assessment of future energy demand. A methodological review providing guidance to developers and users of energy models and scenarios. Lausanne: International Risk Governance Council (IRGC). Online verfügbar unter https://infoscience.epfl.ch/record/228203, zuletzt geprüft am 03. 07.2019.

Jasanoff, Sheila; Kim, Sang-Hyun (2009): Containing the atom. Sociotechnical imaginaries and nuclear power in the United States and South Korea. In: Minerva 47 (2), S. 119-146.

Rip, Arie; Kemp, Réné (1998): Technological change. In: Steve Rayner und Elizabeth Malone (Hg.): Human choice and climate change. Columbus, Ohio: Batelle Press, S. 327-399.

Scheer, Dirk (2013): Computersimulationen in politischen Entscheidungsprozessen. Wiesbaden: Springer vS.

Wesche, Julius; Negro, Simona; Dütschke, Elisabeth; Raven, Rob; Hekkert, Marko (2019): Configurational innovation systems. Explaining the slow German heat transition. In: Energy Research \& Social Science 52, S. 99-113.
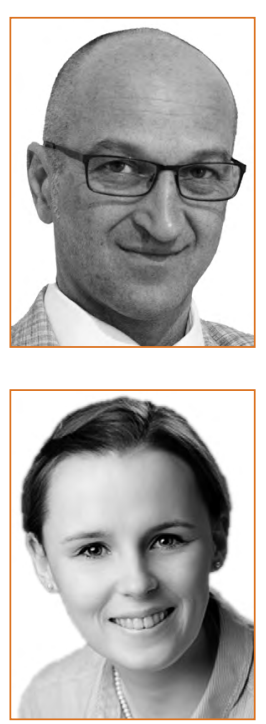

\section{DR. DIRK SCHEER}

ist wissenschaftlicher Mitarbeiter am Institut für Technikfolgenabschätzung und Systemanalyse (ITAS) beim Karlsruher Institut für Technologie (KIT). Seine Forschungsschwerpunkte sind sozialwissenschaftliche Energieforschung, Technologieakzeptanz, Wissenstransfer und -management (science-policy interface) sowie Partizipations- und Risikoforschung.

\section{LISA NABITZ}

ist wissenschaftliche Mitarbeiterin am Institut für Technikfolgenabschätzung und Systemanalyse (ITAS) beim Karlsruher Institut für Technologie (KIT). In ihren Arbeiten befasst sie sich mit sozialwissenschaftlicher Forschung zur Transformation des Energiesystems, derzeit forscht sie u. a. zu Fragen der Multi-Level-Governance im Mobilitätssektor sowie zum gegenwärtigen Zukunftsdiskurs von synthetischen Kraftstoffen. 


\title{
How to deal with non-linear pathways towards energy futures
}

\section{Concept and application of the cross-impact balance analysis}

\author{
Stefan Vögele, Institute of Energy and Climate Research - Systems Analysis and Technology Evaluation (IEK-STE), \\ Forschungszentrum Jülich, 52425 Jülich (s.voegele@fz-juelich.de), (1) orcid.org/0000-0002-5804-0203 \\ Witold-Roger Poganietz, Institute for Technology Assessment and Systems Analysis (ITAS), Karlsruhe Institute of Technology (KIT) \\ (poganietz@kit.edu), (1) orcid.org/0000-0002-5839-1206 \\ Philip Mayer, Chair of Economics, TU Bergakademie Freiberg (philip.mayer@vwl.tu-freiberg.de), (1) orcid.org/0000-0002-8221-6002
}

Energy scenarios currently in use for policy advice are based on a number of simplifying assumptions. This includes, in particular, the linear extrapolation of trends. However, this approach ignores the fact that central variables were highly dynamic in the past. For an assessment of energy futures and the specification of measures, novel approaches are necessary which can implement non-linear trends. In this paper, we show how cross-impact balance ( $\mathrm{CIB}$ ) analysis can be applied to map dynamic trends. Using a small CIB model, we highlight the need for novel approaches in the creation and evaluation of energy futures and the possible contribution of CIB analysis.

\section{Wie lassen sich nichtlineare Entwicklungspfade von Energie- zukünften berücksichtigen? \\ Konzept und Anwendung der Cross-Impact-Analyse}

Den Energieszenarien, die derzeit zur Politikberatung genutzt werden, liegen eine Vielzahl vereinfachender Annahmen zugrunde. Hierzu gehört insbesondere die Fortschreibung von Rahmendaten mittels linearer Trendextrapolation. Ignoriert wird dabei, dass zentrale Größen in der Vergangenheit eine hohe Dynamik aufwiesen. Um Energiezukünfte erstellen, bewerten bzw. Vorschläge zu deren Ausgestaltung angemessen formulieren zu können, bedarf es neuer innovativer Ansätze, in denen nichtlineare Entwicklungen berücksichtigt werden können. In diesem Artikel zeigen wir, wie die Cross-Impact-Balance-Analyse (CIB) zur Abbildung von dynamischen Entwicklungen eingesetzt werden kann. Anhand eines kleinen CIB-Modells verdeutlichen wir die Notwendigkeit für Weiterentwicklungen im Bereich der Erstellung und Bewertung von Energiezukünften und den Beitrag, den die CIB-Analyse dazu leisten kann.

Keywords: energy scenarios, dynamics, cross-impact balance analysis

This is an article distributed under the terms of the Creative Commons Attribution License CCBY 4.0 (https://creativecommons.org/licenses/by/4.0/)

https://doi.org/10.14512/tatup.28.3.20

Submitted: 02.07.2019. Peer reviewed. Accepted: 23.10.2019

\section{Introduction}

Socio-economic systems, like the energy system, are evolutionary systems. Path dependencies and persistence resulting for instance from long lifetimes of technological infrastructures (i. e., power plants) and incumbent energy companies with low interest in radical innovations stabilize the dynamics of the systems (Patel and Pavitt 1997; Safarzynska and van den Bergh 2010). As long as the dynamics of the system do not change, possible futures of the corresponding system can be assessed more or less easily. But, the dynamics of these systems do not only depend on technical innovations (Grubler and Wilson 2013) but also on changes in institutions, socio-economic structures, and policies on local, national, and global level, within and outside the system (Nelson and Winter 2002; Nelson and Winter 1982; Fagerberg 2003; Metcalfe 1994; Witt 2008). Examples for such occurrences are the liberalization of energy markets, or long-run changes in the attitudes of the government and the public towards nuclear power plants in Germany, Sweden, Switzerland and Belgium, which were caused in particular by changes in the composition of the government (World Nuclear Association 2019). Also ups and downs of climate change policies (Zhang et al. 2017), financial crises on an international level as well as arising conflicts between countries (e.g., USA and China/USA and Iraq) can play an important role. Thus, a broad range of authors - including Schumpeter (1943), Veblen (1898), Nelson and Winter (1982) and Faber and Proops (1993) - highlight the need for a closer consideration of non-linear dynamics. Disruptions and discontinuities have been analyzed e. g. by Ayres (2000), Burt (2007), Grossmann (2007), Lempert and Collins (2007) as well as van Notten et al. (2005). However, for reason of simplification, the construction of energy scenarios still relies on the assumption of stable, mostly linear, trends for the development of key factors (like oil prices, or GDP), instead of complex development trajectories. Information on trends is derived from historical data or expert appraisal (Kosow and Gaßner 2008; Bauer et al. 2017). 
Examples for assumed trends of key factors that influence future energy supply and demand are presented in Fig. 1. At the top of the figure, the trends for the development of oil and gas prices used in the newest energy outlook of IEA (2018) are presented. Comparing historical and projected prices, doubts about the reliability of the assumed trajectories (and hence on the resulting scenarios) could arise. Similar concerns could be voiced with regard to the scenarios published by the EU (Capros et al. 2016; EIA 2019).

Thus, working with trends carried out by either extrapolation or expert assessments has some shortcomings:

- Without critical reflections on the persistence of trends in the long term, the use of extrapolated trends may result in a misjudgment of possible dynamics.

- Although the link between key factors and the dynamics within a system are generally recognized, a closer investigation is often not carried out, due to missing expertise or time constraints. Hence, cyclical trends like business cycles or possible breaks in the development of key figures are ignored.

Fluctuating prices for energy carries, business cycles and modifications in the prioritization of policies are examples for challenges that scenarios are faced with. Technological leaps (e. g., digitalization), effects resulting from changes in the zeitgeist (e. g., Fridays for Future movement), modifications in the priority setting of policies as well as international crises (e. g., trade war between countries) are other examples for factors that could disrupt trends.

Studies focusing on climate change or ecosystem analysis highlight "critical thresholds", "critical levels" and "critical loads" as factors behind the occurrence of nonlinearities (IPCC 2001; IPCC 2018). Like ecosystems, thresholds and critical levels are also important in socio-economic systems. For example, the long-run success of development policies crucially depends on passing critical national income thresholds (Azariadis and Drazen 1990). Other examples are social and cultural obstacles that can limit the use of specific technologies as soon as the corresponding technology reaches a "critical" market share. As examples for barriers that limit diffusion of technology beyond a "critical" market share, IPCC listed social norms, individual habits, attitudes, values, and vested interests (IPCC 2001; IPCC 2011).

In principle, thresholds and resulting nonlinearities can impact the efficiency and effectiveness of policy measures as well as the cost of adaptation and mitigation. An appropriate assessment of possible courses of action and their timing requires structured approaches that can deal with thresholds, cycles and the resulting dynamics.

In the following, we present an approach for integrating thresholds and cycles, which allows for the construction of nonlinear storylines. Hence, the presented work contributes to an important strand of scenario development and adds a relevant aspect to the discussion about energy futures (or transformation processes).
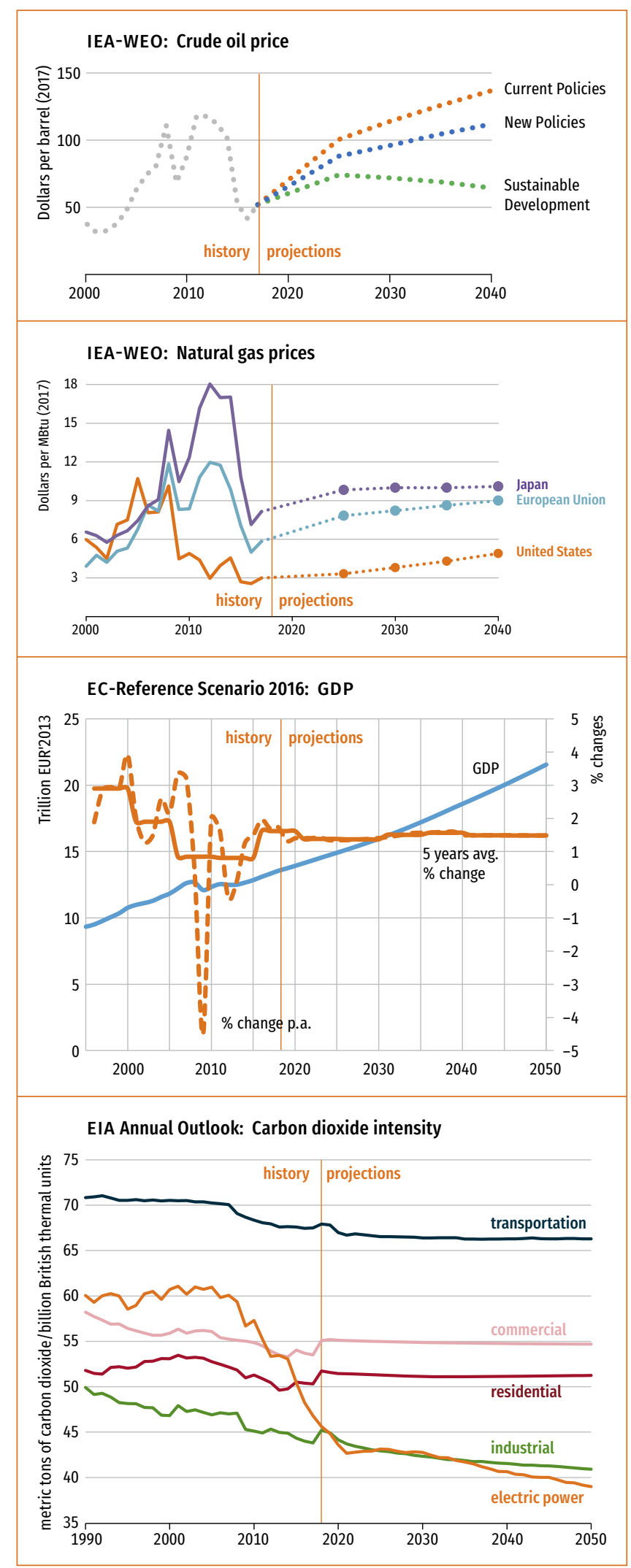

Fig 1: Examples for assumptions on key factors used for the generation of energy scenarios. 


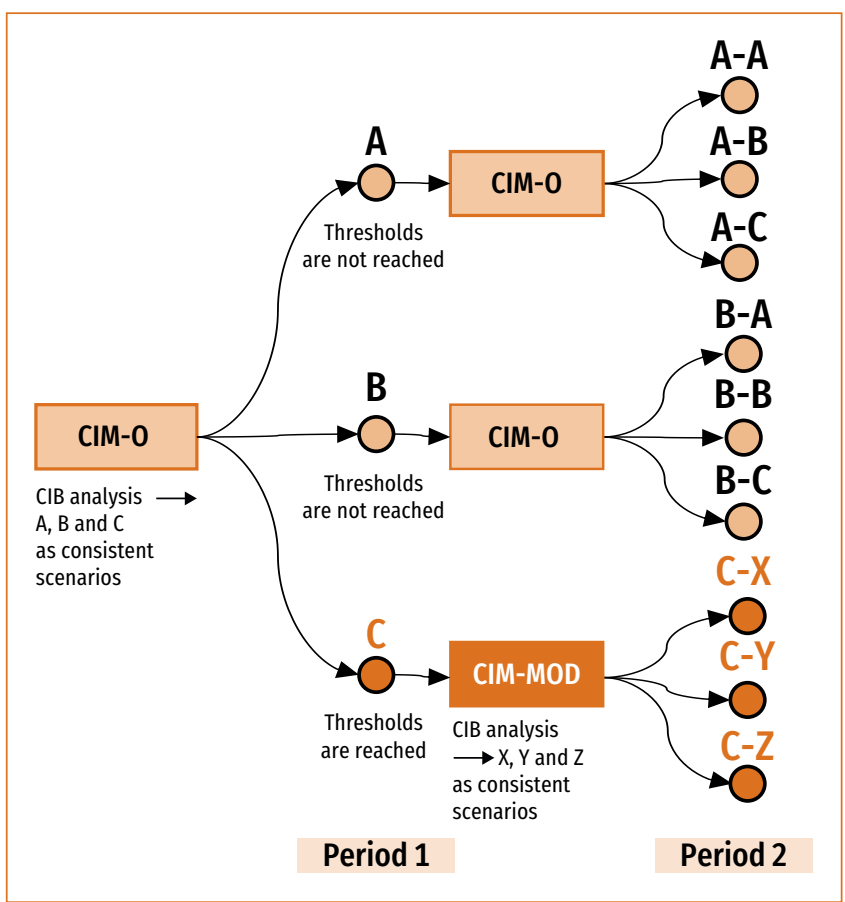

Fig.2: Identification of Transformation Pathways.

Source: Authors' own compilation

\section{Advanced energy modelling - considering non-linearities}

Generally, scenarios are constructed on the base of today's knowledge and expectation about the future (Kosow and Gaßner 2008). Using today's shape of the system under review as a starting point, relevant variables or parameters are extrapolated into the future. This exercise is generally done, without changing the structural relationships within a system.

Historical evidence shows, however, that the structural relationships of a system change over time. Agrarian or emerging societies are functioning differently than industrial or post-industrial ones. This is even true without a complete systems' change (Mathijs and Swinnen 2001; de Bruyn et al. 1998).

Furthermore, historical evidence shows the existence of thresholds, which are connected to a shift of behaviour of societies. If, for example, a society is achieving a specific welfare level the production structure, as well as the demand structure is shifting from more basic mostly energy-intensive products to services and lighter industries (IEA 2016), leading to a decoupling of energy demand from income development. Higher income levels allow for more energy-efficient technologies whereas in a society with low levels of average income changes in income will be used to buy for example electric appliances or cars with lower energy standard (de Bruyn et al. 1998; IEA 2018).

The Cross-Impact-Balance (CIB) approach allows for specifying consistent socio-economic storylines (Weimer-Jehle 2006;
Weimer-Jehle et al. 2016; Schweizer and Kriegler 2012). Similar approaches have been developed and applied in the field of environmental scenario analysis. Examples are the "Story and Simulation" approach (Alcamo and Henrichs 2008), "integrated scenarios" (Döll and Krol 2002), "narratives and numbers" (Kemp-Benedict 2004), and the "hybrid scenarios" approach (Winterscheid 2008).

The core idea of the CIB approach is to find a set of quantitative and qualitative factors, so-called descriptors, and possible (future) states for each descriptor, which could characterize the system under review. Formally speaking the descriptors and states are merged into a cross-impact matrix (CIM), which reveals the interrelationship between the different descriptor-states. By combining possible descriptor-states' arrangements to consistent sets, one or more possible futures of the system can be identified. However, possible changes of the interdependency between descriptor-states are usually not recognized, implying a linear development of the socio-economic system.

In principle, CIB allows for modelling and analyzing thresholds and cycles. A way to overcome the linearity of the CIB approach (i. e., implementing cycles and thresholds) is using descriptor states describing developments (e.g., "increase of GDP for 5 years, followed by a drop in the next 5 years") or introducing sub-periods and crucial descriptors (see Vögele et al. 2018a for more information on advantages and disadvantages of the different approaches). Those descriptors can either trigger a change in interdependencies within the CIM as soon as a certain threshold is reached, or they exhibit cyclic behaviour (i. e., their state in the current sub-period is affected by their state in the previous sub-period).

In the introduced method, the considered period is divided into several sub-periods. Starting with the first sub-period a CIM is constructed and several scenarios are identified, each describing a possible future. These possible futures are analyzed with respect to specific crucial descriptors. In the example depicted in Fig. 2, the CIB analysis reveals a set of three consistent fu-

\section{Historical evidence shows the existence of thresholds, which are connected to a shift of behaviour of societies.}

tures A, B and C for the first sub-period. As soon as a pre-defined threshold is reached, a modified CIM is created, resulting in a new scenario space.

The modified matrix, labelled CIM-MOD in Fig. 2, is used for calculating the next set of scenarios for the description of the subsequent periods following future $\mathrm{C}$. This exercise is repeated until consistent scenarios are generated for all sub-periods. Fol- 


\begin{tabular}{|c|c|c|c|c|c|c|}
\hline Descriptors & Category & $\begin{array}{l}\text { Possible variations } \\
1\end{array}$ & 2 & 3 & 4 & 5 \\
\hline D1: Global economic cohesion & Static & Protectionism & Open economies & $\begin{array}{l}\text { Bilateral trade } \\
\text { agreements }\end{array}$ & & \\
\hline $\begin{array}{l}\text { D2: Trade of energy } \\
\text { commodities }\end{array}$ & Static & Trade restrictions & $\begin{array}{l}\text { No trade } \\
\text { restrictions }\end{array}$ & & & \\
\hline D3: Energy commodity prices & Static & Increase & Constant & Decrease & & \\
\hline D4: GDP Growth & Threshold/Cyclic & $\begin{array}{l}\text { Very small } \\
\text { increase }\end{array}$ & Small increase & Moderate increase & High increase & Very high increase \\
\hline D5: Climate policy & Static & Unambitious & Moderate & Ambitious & & \\
\hline D6: Energy consumption & Threshold & Slight increase & Moderate increase & Strong increase & & \\
\hline
\end{tabular}

Tab.1: Specification of descriptors and their variations.

Source: Authors' own compilation

lowing this approach, a set of consistent, plausible, and non-linear transformation pathways can be identified.

In order to illustrate the modelling of nonlinearity, we apply a CIB model with a set of six descriptors (Tab. 1). We differentiate between three types of descriptors. Static descriptors do not actively trigger non-linear developments. Thus, their mechanism resembles the original CIB method. Interdependencies for threshold descriptors change as soon as a certain limit value is reached. The state of cyclic descriptors in the current period is dependent on their state in the previous sub-period.

As an example for a threshold, we assume that in the beginning, energy consumption increases with economic growth. When the economic growth exceeds a defined level, energy con- sumption will be partially decoupled from the development of national income (e.g., via technologies with higher energy efficiency) (IEA 2016). As another source for nonlinearities, we consider business cycles: We assume that it is likely that a period of high economic growth is followed by a period with lower growth and vice versa.

We compare two illustrative scenarios: One scenario is developed using the original CIB analysis. A second scenario is constructed by employing the introduced methodology of dynamic pathways. The first scenario, which is referred to as "Joint forces" (JF), does not take into consideration dynamic interactions within the time horizon, and thus applies the original CIB method. The second scenario "Eleventh hour" (EH) em-

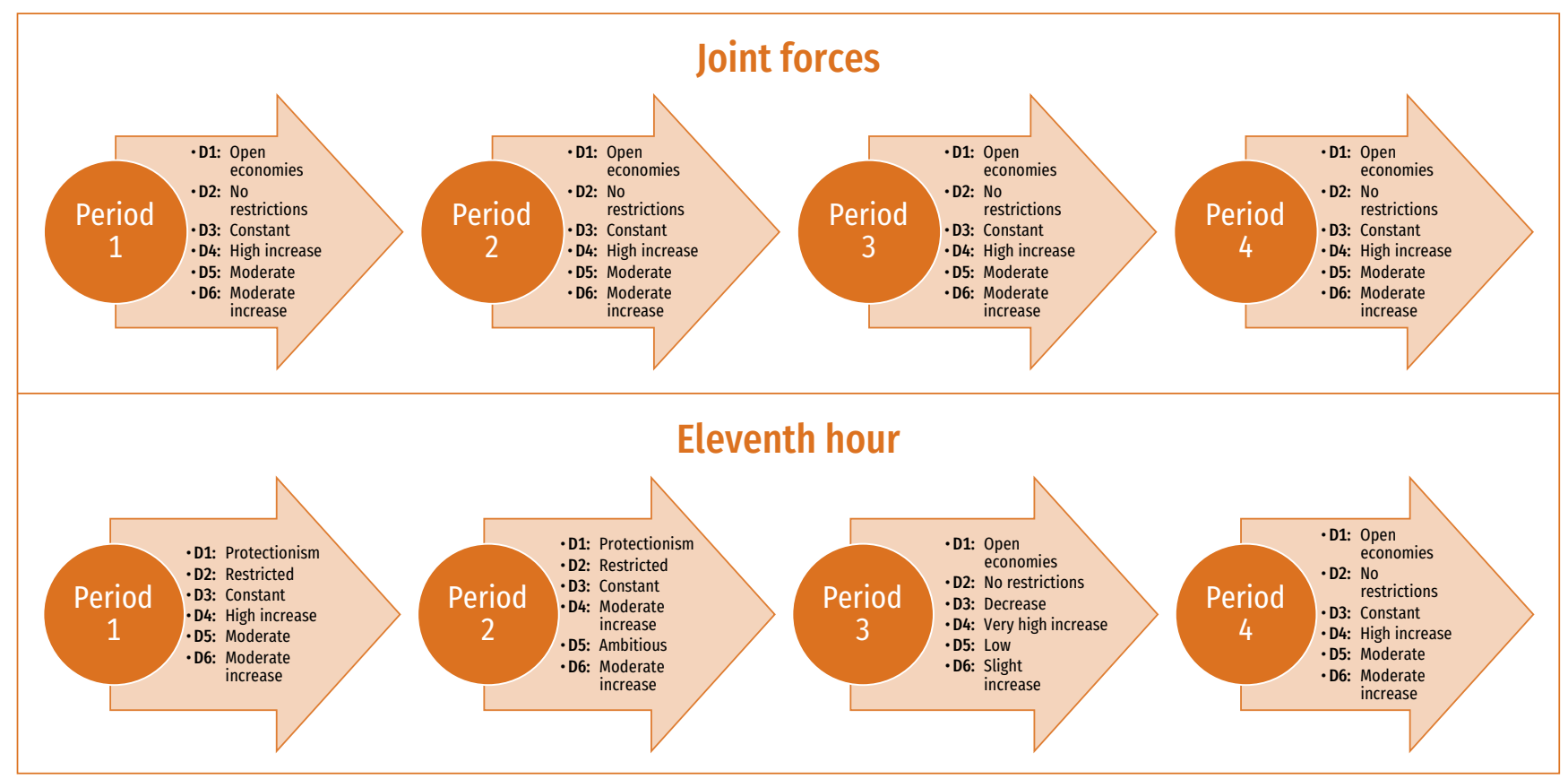

Fig. 3: Development of the descriptor sets in the storylines. 
ploys the introduced methodology of thresholds and cycles. In the last period, both EH and JF show the same set of descriptor states (Fig. 3).

Thus, a comparison of those two scenarios reveals the resulting differences of explicitly modelling dynamic pathways (EH) and assuming linear development trends (JF):

- Joined forces: In this scenario, the international community is characterized by harmony and a high level of cooperation on both economic and environmental issues. High economic growth facilitates investments in the exploration of fossil reservoirs, leading to constant prices for energy carriers. With resilient international trade agreements, economy-wide af- economic situation in the year 2050, the pathways leading to this point in time deviate strongly. JF assumes a linear trend of constant GDP growth, EH shows a fluctuating progression with periods of prosperity, economic booms and subdued growth. This affects the development of the power system via two interlinked channels: (i) due to the assumption of a direct influence of GDP trends on electricity consumption, diverging patterns of economic growth result in different amounts of power demand; (ii) the defined threshold that causes a shift of the interdependence between economic growth and electricity consumption is not triggered in JF. Hence, in this scenario power consumption exhibits a sharper rise, than in EH. Furthermore, the occurring shifts in the prioritization of climate policy are major drivers for

\section{Transformation pathways for energy systems have to be seen as evolutionary processes with nonlinear trends.}

fluence grows constantly. Although damages from climate change increase over time, negative effects are partly offset by strong economic growth. Consequently, climate change policy is only moderately emphasized within the international community. Nevertheless, in order to achieve the set climate goals, coal-fired power plants are slowly phased out, while the power markets transform towards a predominantly renewable energy system.

- Eleventh hour: The global economy thrives, which allows for new investments in the exploration of fossil storage sites. As a result, demand and supply of natural resources stay relatively balanced, leading to stable prices for energy commodities. Political tensions on the international level foster protectionist tendencies. With international collaboration continuously declining in the following years, and damages due to climate change, overall economic growth is constrained. As a result, national policy measures aiming to tackle the impacts of climatic change become more ambitious. However, due to the unfavorable economic setting, willingness to invest in new technological advancements is restrained. A shift in climate policy leads to a rapid phase-out of coal-fired power plants. In order to avoid the looming economic crises, the international community works towards building new institutions that regulate future cooperation. As a result, fuel prices drop. The elimination of trade barriers trigger a time of economic prosperity and wealth. Investments in new infrastructures and energy efficiency technologies lead to a less energy-intensive economy.

The descriptor sets depicted above are implemented into a European electricity market model (see Vögele et al. 2018b for more information on the model). The quantification of the two scenarios reveals distinctive development paths. While both scenarios share a common assumption on the general political and the layout of the future power market. The corresponding descriptor is implemented into the energy market modelling framework through carbon prices. The shifts in climate policy are accompanied by changing trends in energy carrier prices. Consequently, market conditions for power generators are subject to a state of flux, where the profitability of generation types can suddenly change between two periods. This means, that JF shows a steady transition of the electricity market towards a low-carbon system, where coal-fired power plants continuously lose profitability, as prices for $\mathrm{CO}_{2}$ emissions increase constantly. In contrast, EH displays a more abrupt fuel switch from coal to natural gas. Accordingly, the development of greenhouse gas emissions differs between the scenarios (Fig. 4).

As we can see, the sudden shift in climate policy in EH leads to a fast phase-out of coal-fired power plants in 2030. While gasfired power plants do not significantly contribute to the overall $\mathrm{CO}_{2}$ emissions in this scenario, the non-linear scenario shows a more dominant role for natural gas. In the last period, both scenarios display comparatively low emission levels for electricity generation. However, due to the lower electricity demand in $\mathrm{EH}$, overall emissions until 2050 are lower than in JF. Reasons for this development are: (i) the sudden shift in climate change policy leads to more abrupt phase-out of coal-fired power-plants; (ii) periods of lower economic growth lead to overall lower electricity demand; and (iii) the decoupling of electricity consumption and GDP growth additionally decreases electricity demand.

\section{Discussion and conclusion}

Taking developments of the past into consideration, it can be expected that transformation pathways for energy systems have to be seen as evolutionary processes with nonlinear trends. Windows of opportunities as well as times with restricted space for 
changes will characterize these processes. In order to ensure sustainable and efficient target attainment, the timing of the implementation of policy measures is of vital importance. However, only a part of future developments (including occurrence of thresholds or other kinds of disruptions in trends) is ascertainable in advance. Hence, there is a need for approaches that help to assess possible developments, that support the emergence of windows of opportunities, and that improve the perception and refine the senses for the uncertainty of the future. New systematic approaches that explore such dynamic features are vital in order to cre-

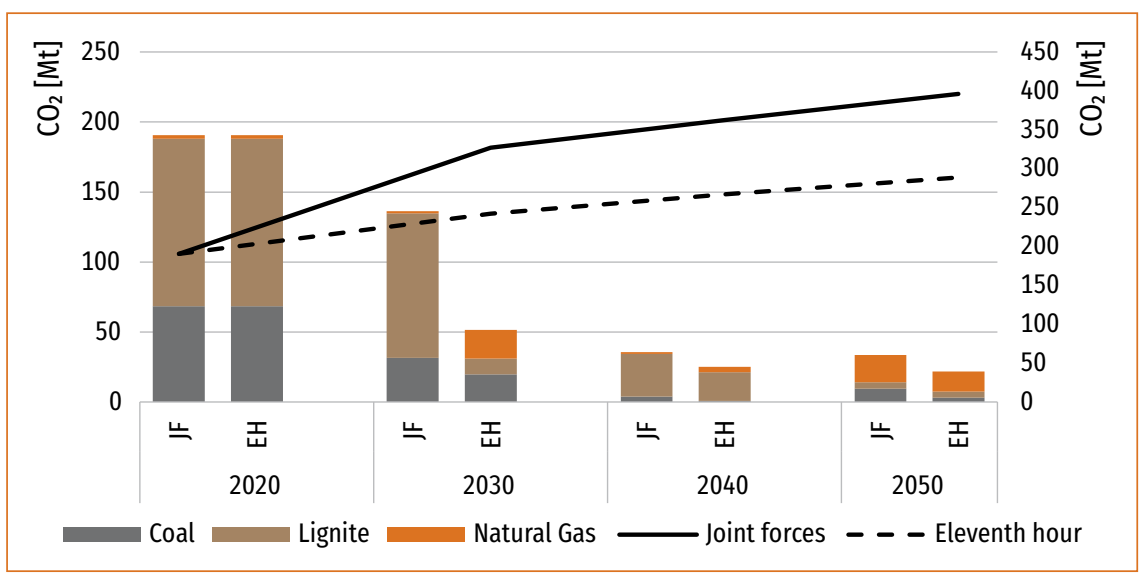

Fig. 4: $\mathrm{CO}_{2}$ emissions by fuel (left axis) and cumulative $\mathrm{CO}_{2}$ emissions (right axis).

Source: Authors' own calculation ate a more comprehensive understanding of possible future developments. In the field of energy and climate research, the presented approach of thresholds and cycles can be utilized to identify a broad variety of nonlinearities, as for example risks of irreversible environmental or climate damages, changes of public attitudes and perspectives, as well as technological leaps. Furthermore, it can shed light on changing market or regulation conditions, that can significantly impact the deployment of energy systems.

With the new methodology presented in this article, we are able to assess impacts of fluctuating parameters, on changing policy attitudes and public perceptions and thresholds or irreversible developments. By linking CIB scenarios, it is possible to describe dynamic storylines. Since (quantitative) energy models usually are used to describe the development of energy systems in 5- or 10-year time steps, the application of such dynamic storylines helps to put storyline and quantitative scenarios in line. The storylines developed based on this rather plain specification show that the pathways to achieve reasonable $\mathrm{CO}_{2}$ reductions do not have to be linear but can be characterized by different kinds of nonlinearities. By laying out the main findings of our approach, we show the need for novel approaches in order to increase our knowledge on possible pathways, which could enhance the effectiveness of policy advice relying on longterm scenarios.

As our example shows, the CIB approach is a very well suited tool for the assessment of plausible future developments. The range of different scenarios carried out by interlinking CIB-scenarios (identified as possible settings for different sub-periods) can be large. While the implementation of this methodology can be challenging due to the high amount of possible scenario configurations, it allows taking into account a broad range of nonlinearities.

\section{References}

Alcamo, Joseph; Henrichs, Thomas (2008): Chapter two towards guidelines

for environmental scenario analysis. In: Developments in Integrated Environmental Assessment 2, pp. 13-35.
Ayres, Robert (2000): On forecasting discontinuities. In: Technological Forecasting and Social Change 65 (1), pp. 81-97.

Azariadis, Costas; Drazen, Allan (1990): Threshold externalities in economic development. In: The Quarterly Journal of Economics 105 (2), pp. 501-526.

Bauer, Nico et al. (2017): Shared socio-economic pathways of the energy sector. Quantifying the narratives. In: Global Environmental Change 42, pp. 316-330. DOI: 10.1016/j.gloenvcha.2016.07.006.

Burt, George (2007): Why are we surprised at surprises? Integrating disruption theory and system analysis with the scenario methodology to help identify disruptions and discontinuities. In: Technological Forecasting and Social Change 74 (6), pp.731-749.

Capros, Pantelis et al. (2016): EU Reference Scenario 2016. Publications Office of the European Union: Luxembourg.

de Bruyn, Sander; van den Bergh, Jeroen; Opschoor, Johannes (1998): Economic growth and emissions. Reconsidering the empirical basis of environmental Kuznets curves. In: Ecological Economics 25 (2), pp. 161-175.

Döll, Petra; Krol, Maarten (2002): Integrated scenarios of regional development in two semi-arid states of North-Eastern Brazil. In: Integrated Assessment 3 (4), pp. 308-320.

EIA - Energy Information Administration (2019): Annual energy outlook 2019. Washington: U. S. Energy Information Administration.

Faber, Malte; Proops, John (1993): Evolution, time, production and the environment. Berlin: Springer-Verlag.

Fagerberg, Jan (2003): Schumpeter and the revival of evolutionary economics. An appraisal of the literature. In: Journal of Evolutionary Economics 13 (2), pp. 125-159.

Grossmann, Iris (2007): Critical and strategic factors for scenario development and discontinuity tracing. In: Futures 39 (7), pp. 878-894.

Grubler, Arnulf; Wilson, Charlie (2013): Energy technology innovation. Learning from historical successes and failures. Cambridge, UK: Cambridge University Press.

IEA - International Energy Agency (2016): World energy outlook. Paris: IEA/OECD.

IEA (2018) World energy outlook. Paris: IEA/OECD.

IPCC - Intergovernmental Panel on Climate Change (2001): Climate change 2001. Mitigation. Cambridge, UK: Cambridge University Press. 
IPCC (2011): IPCC special report on renewable energy sources and climate change mitigation. Cambridge, UK: Cambridge University Press.

IPCC (2018): Global Warming of $1.5^{\circ} \mathrm{C}$. An IPCC Special report on the impacts of global warming of $1.5^{\circ} \mathrm{C}$ above pre-industrial levels and related global greenhouse gas emission pathways, in the context of strengthening the global response to the threat of climate change, sustainable development, and efforts to eradicate poverty. Available online at https://www.ipcc.ch/ sr15/download/\#full, last accessed on 09. 09.2019.

Kemp-Benedict, Eric (2004): From narrative to number. A role for quantitative models in scenario analysis. Available online at http://www.iemss.org/ iemss2004/pdf/scenario/kempfrom.pdf, last accessed on 05.09.2019.

Kosow, Hannah; Gaßner, Robert (2008): Methods of future and scenario analysis. Overview, assessment, and selection criteria. Bonn: Deutsches Institut für Entwicklungspolitik.

Lempert, Robert; Collins, Myles (2007): Managing the risk of uncertain threshold responses. Comparison of robust, optimum, and precautionary approaches. In: Risk Analysis 27 (4), pp. 1009-1026. DOI: 10.1111/j.1539-6924.2007.00940.x.

Mathijs, Erik; Swinnen, Johan (2001): Production organization and efficiency during transition. An empirical analysis of East German agriculture. In: Review of Economics and Statistics 83 (1), pp. 100-107.

Metcalfe, John (1994): Evolutionary economics and technology policy. In: Economic Journal 104 (425), pp. 931-944.

Nelson, Richard; Winter, Sidney (1982): An evolutionary theory of economic change. Cambridge, MA: Belknap Press.

Nelson, Richard; Winter, Sidney (2002): Evolutionary theorizing in economics. In: Journal of Economic Perspectives 16 (2), pp.23-46. DOI: 10.1257/0895330027247.

Patel, Pari; Pavitt, Keith (1997): The technological competencies of the world's largest firms. Complex and path-dependent, but not much variety. In: Research Policy 26 (2), pp. 141-156.

Safarzynska, Karolina; van den Bergh, Jeroen (2010): Evolutionary models in economics. A survey of methods and building blocks. In: Journal of Evolutionary Economics 20 (3), pp. 329-373.

Schumpeter, Joseph (1943): Capitalism, socialism, and democracy. New York: Harper \& Bros

Schweizer, Vanessa; Kriegler, Elmar (2012): Improving environmental change research with systematic techniques for qualitative scenarios. In: Environmental Research Letters 7 (4), pp. 1-14. DOI: 10.1088/1748-9326/7/4/044011.

van Notten, Philip; Sleegers, Am; van Asselt, Marjolein (2005): The future shocks. On discontinuity and scenario development. In: Technological Forecasting and Social Change 72 (2), pp. 175-194.

Veblen, Thorstein (1898): Why is economics not an evolutionary science? In: The Quarterly Journal of Economics 12, pp. 373-397.

Vögele, Stefan; Poganietz, Witold-Roger; Kunz, Paul; Weiss, Annika (2018a): Analyse dynamischer Entwicklungen mittels der Cross-Impact-Balance Methode. Jülich: Forschungszentrum Jülich.

Vögele, Stefan; Rübbelke, Dirk; Mayer, Philip; Kuckshinrichs, Wilhelm (2018b): Germany's "No" to carbon capture and storage. Just a question of lacking acceptance? In: Applied Energy 214, pp. 205-218.

Weimer-Jehle, Wolfgang (2006): Cross-impact balances. A system-theoretical approach to cross-impact analysis. In: Technological Forecasting and Social Change 73 (4) pp. 334-361.

Weimer-Jehle, Wolfgang et al. (2016): Context scenarios and their usage for the construction of socio-technical energy scenarios. In: Energy 111, pp. 956-970.

Winterscheid, Axel (2008): Scenario technique in flood risk management (in German). PhD-thesis. Reports of the Institute for Hydraulic Engineering Vol. 143. Darmstadt: Technical University of Darmstadt (Germany).

Witt, Ulrich (2008): What is specific about evolutionary economics? In: Journal of Evolutionary Economics 18 (5), pp. 547-575. D0I: 10.1007/s00191-008-0107-7.

World Nuclear Association (2019): Country profiles. Available online at http:// www.world-nuclear.org/information-library/country-profiles.aspx, last accessed on 21. 06.2019.

Zhang, Yong-Xiang; Chao, Qing-Chen; Zheng, Qiu-Hong; Huang, Lei (2017): The withdrawal of the U.S. from the Paris Agreement and its impact on global climate change governance. In: Advances in Climate Change Research 8, pp. 213-219. D0I: 10.1016/j.accre.2017.08.005.
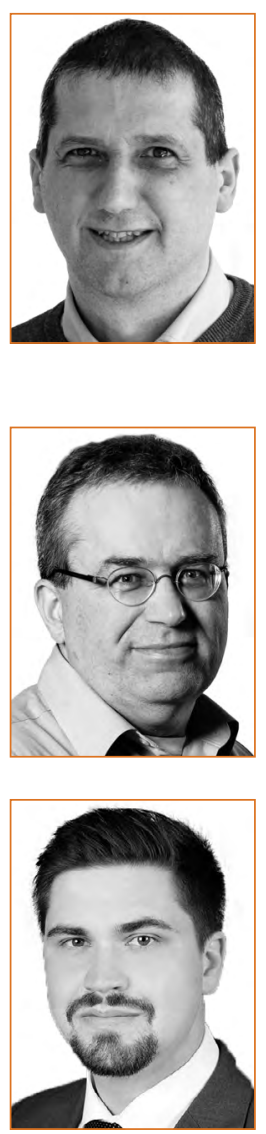

\section{DR.STEFAN VÖGELE}

is employed since 2000 as senior scientist at the Forschungszentrum Jülich, Institute for Energy and Climate Research, Systems Analysis and Technology Evaluation (IEK-STE) with focus on energy economics. He studied economics at the RuprechtKarls-University Heidelberg and received a doctoral degree in economics from Osnabrück University, Germany.

\section{DR. WITOLD-ROGER POGANIETZ}

works at the Institute for Technology Assessment and Systems Analysis (ITAS). His research interests are on socio-technical drivers and impediments of the transformation of energy systems in Europe as well as in countries of the "Global South".

\section{PHILIP MAYER}

is a research associate at the Chair of Economics of TU Bergakademie Freiberg, since 2017. He studied management of renewable energies at Weihenstephan-Triesdorf University of Applied Sciences, Germany and received his masters' degree in energy and resource management at TU Bergakademie Freiberg, Germany. 


\title{
Leitmotive und Storylines der Energiewende
}

\author{
Wie Stakeholder-Positionen systematisch \\ in Transformationspfade integriert werden können
}

Ricarda Schmidt-Scheele, Zentrum für interdisziplinäre Risiko- und Innovationsforschung (ZIRIUS), Universität Stuttgart, Seidenstraße 36, 70174 Stuttgart (ricarda.schmidt-scheele@zirius.uni-stuttgart.de) (D) orcid.org/0000-0003-0491-9981

Dierk Bauknecht, Öko-Institut e.V., Institut für angewandte Ökologie (d.bauknecht@oeko.de) (1) orcid.org/0000-0002-5816-0176

Witold-Roger Poganietz, Institut für Technikfolgenabschätzung und Systemanalyse (ITAS), Karlsruher Institut für Technologie (KIT) (witold-roger.poganietz@kit.edu)

Dominik Seebach, Öko-Institut e.V., Institut für angewandte Ökologie (d.seebach@oeko.de)

Christof Timpe, Öko-Institut e. V., Institut für angewandte Ökologie (c.timpe@oeko.de)

Wolfgang Weimer-Jehle, Zentrum für interdisziplinäre Risiko- und Innovationsforschung (ZIRIUS), Universität Stuttgart

(wolfgang.weimer-jehle@zirius.uni-stuttgart.de) (D) orcid.org/0000-0002-2945-7288

Annika Weiss, Institut für Technikfolgenabschätzung und Systemanalyse (ITAS), Karlsruher Institut für Technologie (KIT) (annika.weiss@kit.edu)

Transformationspfade zu einem nachhaltigen Energiesystem beruhen meist auf modellbasierten Szenarien. In den Szenarien müssen gesellschaftliche Prozesse und deren Interaktion mit technologischen, ökonomischen und ökologischen Aspekten betrachtet werden. Dies setzt u. a. eine Integration zentraler Stakeholder-Positionen in die Szenarien voraus. Hierzu präsentieren wir Ansätze aus zwei Forschungsprojekten: Der erste Ansatz identifiziert gesellschaftliche Leitmotive der Energiewende und analysiert, in welchen technisch-ökonomischen Transformationspfaden diese realisiert werden können. Der zweite Ansatz setzt auf eine partizipative Entwicklung von Storylines, um eine verbesserte Legitimation und Kommunikation von Transformationspfaden zu erreichen. Wir diskutieren die Herangehensweisen beider Ansätze, die Positionen von Stakeholdern methodisch zu erfassen und mit technisch-ökonomischen Perspektiven zur Energiesystemtransformation zu verknüpfen.

\section{Guiding motives and storylines of the German energy transition} How to systematically integrate stakeholder positions into energy transformation pathways

Pathways towards sustainable energy transformations are usually premised on model-based scenarios. These scenarios have to incorporate societal dynamics and their interaction with technological, economic, and ecological processes. This also requires the consideration and integration of the stakeholders' positions into the scenarios. For this purpose, we present two different approaches: the first one identifies the stakeholders' guiding motives regarding the German energy

This is an article distributed under the terms of the Creative Commons Attribution License CCBY 4.0 (https://creativecommons.org/licenses/by/4.0/)

https://doi.org/10.14512/tatup.28.3.27

Submitted: 28.06.2019. Peer reviewed. Accepted: 23.10.2019 transition and analyzes how these positions can be realized in technological and economic transformation pathways. In the second approach, storylines are developed in a participatory process with the stakeholders to ensure increased legitimacy and communication of the resulting pathways. For both approaches, we discuss the methodological capture of stakeholder positions and their subsequent integration into energy transformation pathways.

Keywords: energy system transformation, energy scenarios, energy values, stakeholder involvement

\section{Einleitung}

In der Transformationsforschung findet der Ansatz, modell-basierte Energieszenarien mit systematischen Ausarbeitungen gesellschaftlicher und politischer Kontexte zu kombinieren, zunehmende Aufmerksamkeit. Hierzu kann auf eine Reihe von Methoden verwiesen werden (Nakićenović 2000; Weimer-Jehle et al. 2013; Trutnevyte et al. 2014). Wissenschaftlich fundierte Einschätzungen darüber, unter welchen gesellschaftlichen Bedingungen technisch-ökonomische Entwicklungspfade realisiert werden können, stellen einen wichtigen Schritt in Richtung einer Systematisierung von Kontextunsicherheit und -komplexität dar. In diesem Zusammenhang wird von der interdisziplinären Energieforschung gefordert, mögliche Transformationspfade nicht lediglich ex-post hinsichtlich der Positionen von Stakeholdern zu bewerten, sondern ebendiese bereits bei der Konstruktion von Transformationspfaden zu berücksichtigen (Berkhout 2006). 


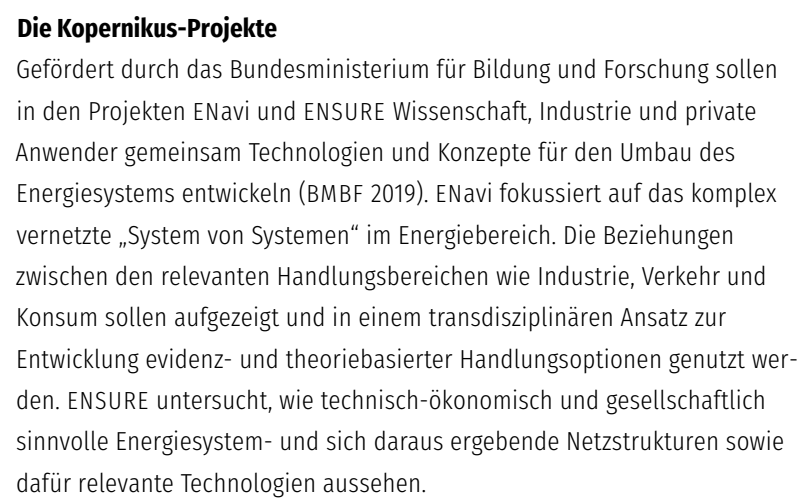

Ein Argument für diese Vorgehensweise ist die daraus resultierende Plausibilität der Pfade. Die Einbindung von Stakeholder-Positionen reflektiert die tatsächliche Vielschichtigkeit soziotechnischer Transformationen. Zudem fördert sie auch die Legitimität und potenzielle Wirksamkeit von Szenarien in der Beratung von Entscheidungsträgern, da kollektive Zukunftsvorstellungen und Visionen als wesentliche Motivation und Orientierung von Akteurshandeln eingeschätzt werden (Heyen et al. 2018, S. 18).

Stakeholder-Positionen umfassen Wissensbestände, die in der Transformationsforschung als Ziel- und Orientierungswissen konzeptualisiert werden (Becker und Jahn 1999). Sie beinhalten grundsätzliche Zielvorstellungen in Form präferierter Maßnahmen oder Technologien (Mielke et al. 2016), aber auch Grundprinzipien zur Ausgestaltung der Energiewende, z. B. eine faire Verteilung von Lasten und Risiken (Cuppen et al. 2016). Im Gegensatz zu den meist qualitativen Positionen generieren Modellierungen wichtiges Systemwissen auf Basis klar definierter technischer und ökonomischer Parameter. Vor diesem Hintergrund widmen wir uns zwei methodischen Herausforderungen der Transformationsforschung: 1) Wie können Stakeholder-Positionen empirisch identifiziert und systematisch aufgearbeitet werden? 2) Wie können die Positionen nicht nur additiv mitberücksichtigt, sondern in das technisch-ökonomische Systemwissen integriert werden? Die Forschungsprojekte ENavi und ENSURE präsentieren hierzu unterschiedliche methodische $\mathrm{Zu}$ gänge. Beide Projekte haben das Ziel, Transformationspfade zu entwickeln, die technisch-ökonomisch machbar sind, aber auch gesellschaftlich akzeptiert werden. Wir vergleichen die Ansätze hinsichtlich der methodischen Herausforderungen und diskutieren, welche Implikationen sich für die Nutzung der Ergebnisse durch Entscheidungsträgern ergeben.

\section{Leitmotive der Energiewende}

Modellierte Transformationspfade verwenden häufig politische Zielvorgaben als Ausgangspunkte, z. B. die Reduktion von Treibhausgasemissionen bis 2050 um 80-95\% gegenüber 1990 .
Diese Vorgaben definieren die Ziele der Transformation, jedoch nicht die möglichen Wege dorthin. Es verbleibt ein Möglichkeitskontinuum zielerfüllender Transformationspfade. Um die Vielzahl der möglichen Pfade vor dem Hintergrund gesellschaftlicher Entwicklungen aufzugliedern und diskutierbar zu machen, werden im Projekt ENavi Leitmotive der Energiewende herangezogen.

\section{Prozessbeschreibung}

Unter Leitmotiven verstehen wir Vorstellungen von Stakeholdern darüber, wie und nach welchen Prinzipien der Transformationsprozess gestaltet werden soll. Leitmotive sind implizit oder explizit in der Gesellschaft vorhanden. Dieser Ansatz basiert auf den Konzepten Leitbilder (de Haan 2001) und Leitorientierungen (Gleich et al. 2010), die beide in der Transformationsforschung genutzt werden, um kollektive Vorstellungen, basierend auf Werten und Weltbildern, gesellschaftlich zu verhandeln. Eine besondere methodische Herausforderung besteht darin, dass sie Zielvorstellungen anschaulich hervorheben, jedoch ,,in aller Regel noch keine Aussagen über die hierfür notwendigen konkreten Maßnahmen zur Erreichung machen" (Giesel 2007, S. 77). Wir verwenden Leitmotive als Analysekonzept. Es nimmt im besonderen Maße einzelne, tiefer liegende Beweggründe für bestimmte Positionen in den Blick (Rosenstiel 2007) und versteht sie als orientierungs- und handlungsleitend für Stakeholder in Bezug auf deren Transformationsentscheidungen.

Die Identifizierung von Leitmotiven im gesellschaftlichen Diskurs erfolgt im Rahmen einer qualitativen Inhaltsanalyse von Primärquellen (de Haan 2001). Ausgewertet werden Positionspapiere zur Energiewende, die eine Vielfalt von Positionen und Interessen beinhalten (u. a. Kommunen, Wirtschafts- und Umweltverbände, Energieerzeuger, Netzbetreiber). In der Dokumentenanalyse werden die Kategorien Wunsch- (was wird als wünschenswertes Ziel erachtet?) und Machbarkeitsprojektionen (was kann und soll in der Zukunft erreicht werden?) genutzt. Zusätzlich wird codiert, welche Rollen und Verantwortlichkeiten unterschiedlichen Akteuren zugeschrieben werden. Das Ergebnis sind verdichtete Beschreibungen der Leitmotive. Insgesamt werden sieben Leitmotive identifiziert. Neben dem in Tab. 1 verkürzt dargestellten exemplarischen Leitmotiv sind dies Energiewende als Generationenprojekt, die minimalinvasive Ener-

\footnotetext{
Energiewende als Chance für die gesellschaftliche Modernisierung

Die notwendigen Umbrüche im Energiesystem werden als Chance gesehen, verfestigte Strukturen aufzubrechen und sie durch eine verstärkte Demokratisierung und Partizipation zu ersetzen. Wie die Energiewende zu gestalten ist, wird kontinuierlich diskutiert und verhandelt werden. Planung und Realisierung von Infrastrukturvorhaben auf lokaler Ebene durch lokale Akteure (Bürgerenergiegesellschaften, Stadtwerke, Kommunen) bieten die Gelegenheit für ein gestärktes bürgerliches Engagement.
}

Tab.1: Exemplarisches Leitmotiv der Energiewende. Quelle: Eigene Darstellung 
giewende, EU in der energiepolitischen Führungsrolle, Deutschland als energiepolitischer Vorreiter in der Welt, Energiewende als Motor für Chancengleichheit zwischen den Regionen der BRD, Energiewende zur Erhaltung von Umwelt und Natur.

Für die Integration der Leitmotive in technisch-ökonomisches Systemwissen werden Technosphären konstruiert. Basis für die Konstruktion bilden 22 für die Energiewende zentrale Richtungsentscheidungen in den Sektoren Strom, Wärme und Mobilität, die zuvor von einem interdisziplinären Projektteam identifiziert wurden (Bauknecht et al. 2018) und als Input-Parameter für die Technosphären dienen. In einem interdisziplinären Workshop mit ExpertInnen aus der Energiesystemanalyse sowie den Sozial- und Ingenieurwissenschaften werden mit der Cross-Impact-Bilanzanalyse (CIB) jeweils paarweise die gegenseitigen Beeinflussungen zwischen allen Richtungsentscheidungen bewertet, z. B. welchen Einfluss ein früherer Kohleausstieg auf die Struktur ,Stromerzeugung durch erneuerbare Energien“ haben kann. Die Einflüsse werden auf einer Skala von -2 (stark hemmend) bis +2 (stark fördernd) codiert. Abb. 1 zeigt schematisch den Prozess anhand von vier der 22 betrachteten Richtungsentscheidungen. Es ergibt sich ein komplexes Netz aus sich gegenseitig hemmenden und fördernden Richtungsentscheidungen. Mithilfe des CIB-Algorithmus werden 203 konsistente Technosphären, d. h. Bündel aus sich gegenseitig überwiegend fördernden Richtungsentscheidungen identifiziert (für mehr Details siehe Weimer-Jehle 2006).

\section{Zentrale Ergebnisse}

Ziel des Ansatzes ist es herauszufinden, welche Technosphären die identifizierten Leitmotive umsetzen und welche Leitmotive durch keine der konsistenten Technosphären realisiert werden können. Dazu bewertet das Projektteam mithilfe der CIB, wie vereinbar jede Richtungsentscheidung mit den in den Leitmotiven verfolgten Prinzipien ist. Alle Richtungsentscheidungen und Leitmotive wurden vor der Bewertung durch erklärende Essays beschrieben, um eine gemeinsame Bewertungsbasis zu gewährleisten. So wird ein Verbot fossiler Heizungen z. B. als wenig verträglich mit dem Leitmotiv „Gesellschaftliche Modernisierung “ bewertet $(-2)$, da dies ohne einen vorgeschalteten gesellschaftlichen Aushandlungsprozess als Eingriff in das für das Leitmotiv essenzielle partizipative Mitbestimmungsrecht einge- schätzt wird. Innerhalb einer Technosphäre entsprechen die einzelnen Richtungsentscheidungen einem Leitmotiv besser (grün), schlechter (orange) oder haben keinen Einfluss auf die Realisierung eines Leitmotivs (farblos). Tab. 2 zeigt dies an zwei verschiedenen Technosphären und dem Leitmotiv „Energiewende als Chance der gesellschaftlichen Modernisierung“. Insgesamt ergibt sich ein Score, mit dem bestimmt werden kann, welche der 203 Technosphären besonders konsistent oder inkonsistent mit den Leitmotiven sind. Von allen Technosphären unterstützen 146 dieses Leitmotiv (Range: +1 bis +12 ); 41 hemmen das Leitmotiv mehrheitlich (Range: -1 bis -8 ).

\section{Partizipative Storylines}

In ENSURE bringen Stakeholder ihre Positionen mithilfe von selbst entwickelten Storylines ein und begleiten über zwei Jahre deren Umsetzung in modellbasierte Energieszenarien. Die Storylines sollen konsistente, mögliche Entwicklungen in den rele- 


\begin{tabular}{|c|c|c|}
\hline \multirow[b]{2}{*}{ Richtungsentscheidungen } & \multicolumn{2}{|c|}{$\begin{array}{l}\text { Verträglichkeit des Leitmotivs „Energiewende als Chance der gesellschaftlichen Modernisierung“ } \\
\text { mit den zwei beispielhaften Technosphären (siehe Abb.1) }\end{array}$} \\
\hline & Technosphäre 1 (Score +12) & Technosphäre 2 (Score -8) \\
\hline A. Effizienz vs. EE-Nutzung & A2 Fokus auf erneuerbare Energien & A1 Fokus Effizienz/Dämmung \\
\hline B. Wärmenetze & B1 Ausbau Wärmenetze & B1 Ausbau Wärmenetze \\
\hline C. Heiztechnologie & C1 Verbot fossiler Heizungen & C1 Verbot fossiler Heizungen \\
\hline D. Power-to-Heat & D1 Starker P2H Einsatz & D1 Starker P2H Einsatz \\
\hline E. Emissionsreduktionsziele & E3 $100 \%$ Reduktion & E1 $80 \%$ Reduktion \\
\hline F. Strombedarf & F1 Steigend & F1 Steigend \\
\hline G. Fokus Deutschland/EU & G1 Fokus Deutschland & G2 Fokus EU \\
\hline H. Kohleausstieg & H1 Schneller Kohleausstieg & H2 Mittelfristiger Kohleausstieg \\
\hline I. Netzausbau vs. Alternativen & 12 Alternativen & 12 Alternativen \\
\hline J. Flexibilitätsoptionen & J3 Sektorkopplung & J5 Power-to-Gas \\
\hline K. Allgemeine Steuerungsformen & K3 Eigenverbrauch & K4 Zentrale Optimierung \\
\hline L. Antriebsarten & L2 Graduelle Elektrifizierung/Effizienzsteigerung & L3 Keine spezifische Förderung von Antriebstechnologien \\
\hline M. EE-Versorgung (Verkehr) & M1 Fokus EE-Strom im Verkehr & M3 Fokus alternative Kraftstoffe \\
\hline N. Sharing (Multimodalität) & N2 Sharing wird dominanter Lebensstil & N1 Sharing bleibt in der Nische \\
\hline O. Stadtplanung & O3 Starker Infrastrukturumbau ÖPNV/Rad & 01 MIV bleibt im Zentrum der Stadtplanung \\
\hline P. Rolle von Gasnetzen & P2 EE-Integration & P2 EE-Integration \\
\hline Q. Power-to-X & Q1 Fokus Direktstromnutzung & Q3 Fokus Methan \\
\hline R. Nutzung von Bioenergie & R1 Fokus Stromsektor & R1 Fokus Stromsektor \\
\hline S. Fossile KWK-Erzeugung & S1 KWK als kurzfristige Brückentechnologie & S2 KWK als mittelfristige Brückentechnologie \\
\hline T. Struktur der EE-Erzeugung & T3 Viel PV & T2 Offshore \\
\hline U. EE-Verteilung & U2 Dezentrale Verteilung & U1 Zentrale Verteilung \\
\hline V. Verkehrsvermeidung & V3 Maximale Verkehrsvermeidung & V1 Personen- und Güterverkehr steigt \\
\hline
\end{tabular}

Tab.2: Bewertung der Verträglichkeit zweier Technosphären mit einem Leitmotiv. Der Score ergibt sich aus der Addition der Punkte: dunkelorange $(-2)$, hellorange $(-1)$, dunkelgrün $(+2)$, hellgrün $(+1)$, farblos $(0)$.

vanten Sektoren bis 2030 beschreiben, den Raum der aus heutiger Sicht realistisch erscheinenden Entwicklungen aufspannen und die energiepolitischen Positionen der Stakeholder abdecken.

\section{Prozessbeschreibung}

Die Stakeholder werden in einem mehrstufigen Prozess ausgewählt. Zunächst wertet das Projektteam aktuelle energie- und klimapolitische Stellungnahmen von Verbänden und Organisationen aus unterschiedlichen gesellschaftlichen und wirtschaftlichen Bereichen aus und synthetisiert die Positionen zu 20 Kernfragen (Netzausbau, Klimaschutz, Sektorenkopplung, räumliche Verteilung Erneuerbare Energien, etc.). Darauf basierend werden elf Stakeholder identifiziert, die eine Bandbreite der Debatten widerspiegeln. Somit werden nicht nur Vertreter der Energiewirtschaft sowie Umwelt- und Naturschutzverbände eingeladen, sondern auch Arbeitnehmer- und Verbrauchervertreter sowie Vertreter von Kommunen und der Land- und Forstwirtschaft. In sieben Workshops treffen die Stakeholder wesentliche Entscheidungen zur Gestaltung der Storylines und legen Grundlagen für die Bewertung der Storylines und der hierauf aufbauenden Szenarien fest, siehe Abb. 2.

Die Aufgaben der WissenschafterInnen beschränken sich auf die Aufstellung des methodischen Rahmens und der Bereitstellung von Expertenwissen. Die Storylines werden mithilfe von 29 überwiegend qualitativen, das Energiesystem kennzeichnenden „Deskriptoren“ beschrieben; für die modellbasierten Szenarien werden sie in Abstimmung mit den Stakeholdern in quantitative Kenngrößen übersetzt und als Inputgrößen in die Modelle implementiert.

\section{Zentrale Ergebnisse}

Folgende vier Storylines werden entwickelt und dafür jeweils ein Szenario berechnet: 
Bildung der differenzierten Stakeholder-Gruppe

Gemeinsame Diskussion und Definition von Deskriptoren

Erster Entwurf der Storylines

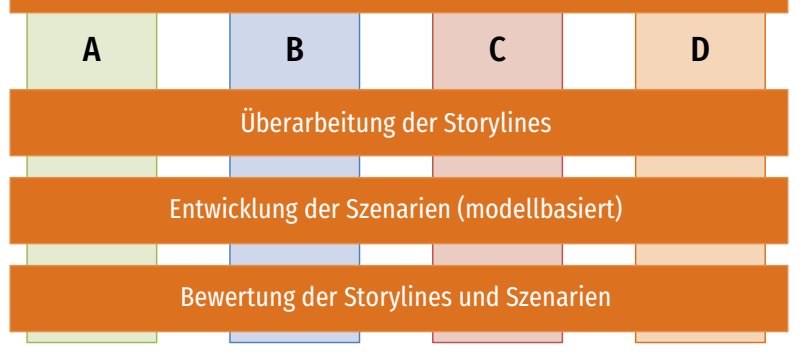

Abb.2: Arbeitsprozess zur Entwicklung der Storylines und Szenarien. Quelle: Eigene Darstellung

a) Referenzentwicklung;

b) Sehr ambitionierter Klimaschutz;

c) Stärker europäisch orientierte Energiewende mit ambitionierten Klimazielen;

d) Dezentrale Energiewende mit ambitionierten Klimazielen.

Storyline A geht von energiewirtschaftlichen Rahmendaten aus, wie sie im Netzentwicklungsplan 2030 (Szenario B, Version 2019) durch die Bundesnetzagentur festgelegt werden. Im Vergleich zu den anderen Storylines weist Storyline A das geringste klima-bezogene Ambitionsniveau auf. Die Treibhausgasemissionen würden hier bis 2030 um $55 \%$ gegenüber 1990 sinken. Das Ambitionsniveau der Storyline B zielt hingegen auf eine stringente Einhaltung des 2-Grad-Ziels. Die THG-Emissionen würden bis 2030 um $78 \%$ sinken. Storyline B bewegt sich damit jenseits der Grenze bisher ausgearbeiteter Energieszenarien und erfordert deutlichere System- und Verhaltensänderungen. Die Ambitionsniveaus der Storylines $\mathrm{C}$ und $\mathrm{D}$ entsprechen dem Mindestanspruch des Pariser Klimaschutzabkommens, THG-Emissionen würden in beiden Fällen um $67 \%$ sinken.

Auf Wunsch der Stakeholder werden Energieszenarien entwickelt, die weit über die Klimaschutzziele der Bundesregierung hinausgehen. Diese Diskussionen gehen von der Einbindung der deutschen Energiewende in die europäische Energie- und Klimapolitik sowie der Elektrifizierung von Wärme und Mobilität aus (Abb. 3). Zwar wird dem Klima- schutz eine herausragende Bedeutung beigemessen, in der Bewertung der Storylines durch die Stakeholder zeigt sich jedoch auch die hohe Relevanz sozio-ökonomischer und umweltbezogener Wirkungen der Szenarien.

\section{Diskussion}

Beide Ansätze liefern unterschiedliche Zugänge zu den zentralen Fragen des Beitrags. Der Leitmotiv-Ansatz entspringt der Annahme, dass Stakeholder-Positionen durch Weltbilder und Werte erklärt werden können. Leitmotive dienen dabei der Rekonstruktion tieferliegender Motive und bündeln Ziel- und Orientierungswissen gesellschaftlicher Akteure. Die methodische Herangehensweise kann eine Vielzahl von gesellschaftlichen Akteuren berücksichtigen, ohne dass die Analyse auf die Prozessteilnahme der Stakeholder angewiesen ist. Identifizierung und Ausgestaltung der Leitmotive basieren jedoch maßgeblich auf einer Interpretation des Forscherteams. Im Gegensatz dazu fokussiert der Storyline-Ansatz auf die Aushandlung von gemeinsam akzeptierten Richtungsentscheidungen, die eine Bandbreite gesellschaftlich erwünschter Energiezukünfte repräsentieren. In Anlehnung an Giesel (2007, S. 161) werden die Vorgehensweisen als analytisch-antizipativ versus diskursiv unterschieden. Ersteres wird in der Leitmotiv-Entwicklung genutzt, um die Implikationen identifizierter Leitmotive für die zukünftige Ausgestaltung des Energiesystems zu untersuchen. Leitmotive sind eine Art analytische Brille, mit der idealisierte „wenn-dann“-Analysen durchgespielt werden können: Welche Transformationspfade sind möglich, wenn sich das eine oder andere Leitmotiv in der Gesellschaft durchsetzt? Die Spiegelung von Leitmotiven an

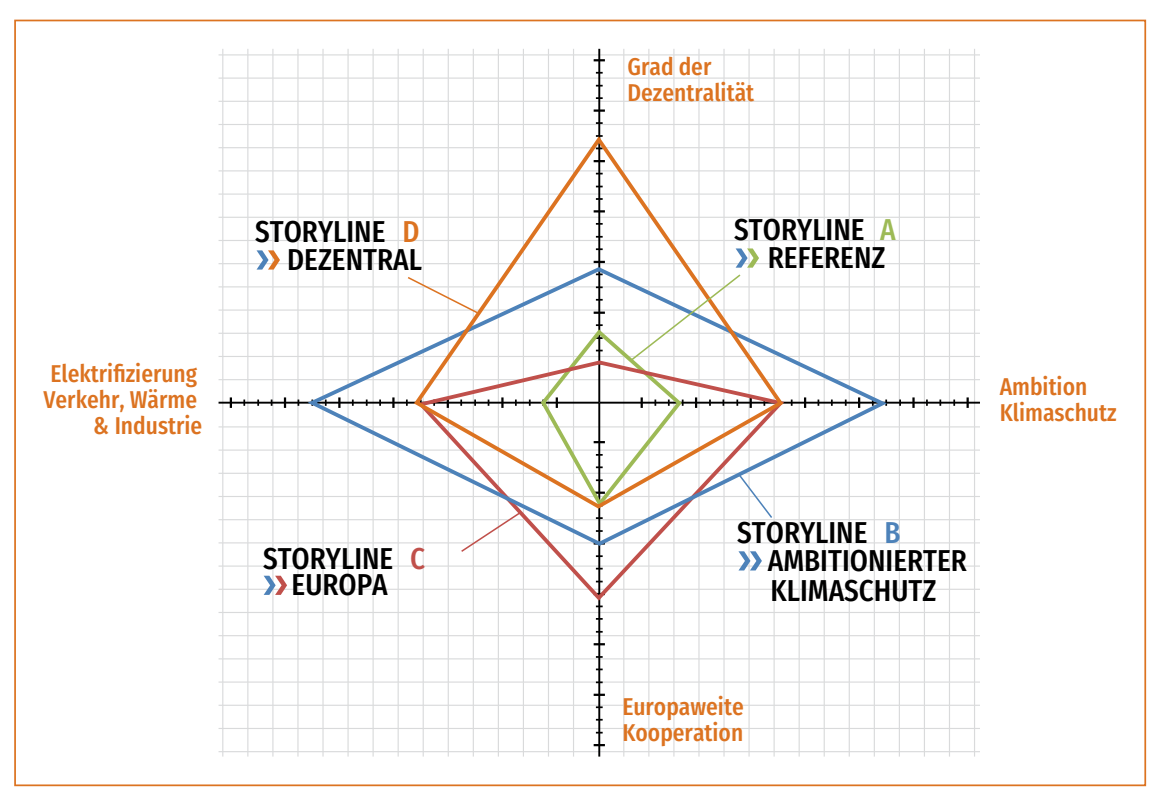

Abb.3: Charakteristische Merkmale der Storylines.

Quelle: Eigene Darstellung. Bildrechte: Schleswig-Holstein Netz AG 
einer großen Anzahl von Technosphären bietet die Möglichkeit, Stakeholder-Positionen und deren Einflüsse auf einen Transformationsprozess systematisch zu analysieren. Eine Herausforderung besteht darin, die Kompatibilitäten zwischen den technologisch-ökonomischen Richtungsentscheidungen und den Leitmotiven zu bewerten, da letztere in ihrer Natur qualitativ und vielschichtig sind. Die Nutzung der CIB schafft hier Transparenz, indem neben den Bewertungen auch qualitative Begründungen erfasst werden. Am Ende der Analyse stehen keine ,ready-to-use“ Ergebnisse; der methodische Ansatz bietet aber die Möglichkeit, gesellschaftliche Zukunftsvisionen und deren Implikationen für technisch-ökonomische Entscheidungsmöglichkeiten transparent aufzuarbeiten.

\section{Der methodische Ansatz ermöglicht}

\section{es, gesellschaftliche Zukunfts- visionen und deren Implikationen transparent aufzuarbeiten.}

Der diskursive Ansatz im Kontext der Storyline-Entwicklung ermöglicht eine Beteiligung ausgewählter Akteure in den Entwicklungsprozess von Szenarien (Timpe et al. 2018) und zielt auf eine Verknüpfung der Wissensbestände ab. Eine Gegenüberstellung wird nicht angestrebt, stattdessen werden iterative Modellierungsläufe genutzt, um Stakeholder-Positionen mit technischen Ausgestaltungsmöglichkeiten zu verknüpfen. Die Verknüpfung erfolgt durch die „Übersetzung“ qualitativer Deskriptoren in quantitative Kenngrößen. Für die Festlegung konkreter Zahlenwerte ist eine Verständigung darüber notwendig, welche Ausprägung die jeweiligen Deskriptoren annehmen dürfen, um kompatibel zu der ausgewählten Storyline zu sein. Ein ambitioniertes klimapolitisches Ziel wie in Storyline B impliziert z. B. einen relativ hohen Kohlenstoffdioxidpreis.

\section{Fazit}

Ergebnisse der diskursiven und analytisch-antizipativen Vorgehensweise können für die Ausgestaltung von Energiezukünften in unterschiedlicher Weise genutzt werden. Wird im Rahmen der Technikfolgenabschätzung davon ausgegangen, dass existierende Leitmotive zukünftige technische und ökonomische Entwicklungen beeinflussen, so hilft der Leitmotiv-Ansatz, mögliche Konsequenzen prospektiv zu erkennen und zu bewerten. Der Storyline-Ansatz zielt stärker auf energiepolitische Entscheidungen. Storylines und die daraus entwickelten Modellierungsergebnisse können direkt in der politischen und gesellschaftlichen Debatte aufgenommen werden. Positionen vom Projekt „externer“ Stakeholder können gegen die entwickelten Storylines gespiegelt und diskutiert werden. Diskurse über unterschiedliche gesellschaftliche Positionen können langfristig dazu beitragen, alternative Leitmotive herauszubilden und zu gesellschaftlich akzeptierten Richtungsentscheidungen zu formulieren (Canzler und Dierkes 2001) und dabei helfen, Leitmotive in partizipative Prozesse als zusätzliche Argumentationshilfen einzuspeisen. Beide hier präsentierten Ansätze schließen sich also keineswegs aus; sie eignen sich vielmehr als ergänzende Instrumente der Technikfolgenabschätzung und -gestaltung.

\section{Literatur}

Bauknecht, Dierk et al. (2018): Pfadentscheidungen der Energiewende. Ein Bericht im Rahmen des Kopernikus-Projekts ENavi. Potsdam: IASS. Online verfügbar unter https://www.oeko.de/fileadmin/oekodoc/ Pfadentscheidungen-Energiewende.pdf, zuletzt geprüft am 18. 10.2019. Becker, Egon; Jahn, Thomas (1999): Sustainability and the social sciences. A cross-disciplinary approach to integrating environmental considerations into theoretical reorientation. London: Zed Books.

Berkhout, Frans (2006): Normative expectations in systems innovation. In: Technology Analysis \& Strategic Management 18 (3-4), S. 299-311. BMBF - Bundesministerium für Bildung und Forschung (2019): Kopernikus Projekte. Die Zukunft unserer Energie. Online verfügbar unter https://www.kopernikus-projekte.de/, zuletzt geprüft am 27.06.2019. Canzler, Weert; Dierkes, Meinolf (2001): Informationelle Techniksteuerung Öffentliche Diskurse und Leitbildentwicklungen. In: Politische Vierteljahres schrift, Sonderheft 31 „Politik und Technik. Analysen zum Verhältnis von technologischem, politischem und staatlichem Wandel am Anfang des 21. Jahrhunderts" hg. von Georg Simonis und Thomas Saretzki, S. 457-475. Cuppen, Eefje; Bosch-Rekvelt, Marian; Pikaar, Ewout; Mehos, Donna (2016): Stakeholder engagement in large-scale energy infrastructure projects. Revealing perspectives using Q methodology. In: International Journal of Projekt Management 34, S. 1347-1359.

de Haan, Gerhard (2001): Die Leitbildanalyse. Ein Instrument zur Erfassung zukunftsbezogener Orientierungsmuster. In: Gerhard de Haan, Ernst-Dieter Lantermann, Volker Linneweber und Fritz Reusswig (Hg.): Typenbildung in der sozialwissenschaftlichen Umweltforschung. Wiesbaden: Springer vs. Giesel, Katharina (2007): Leitbilder in den Sozialwissenschaften. Begriffe,

Theorien und Forschungskonzepte. Wiesbaden: vs Verlag für Sozialwissenschaften.

Gleich, Arnim von; Brand, Urte; Stührmann, Sönke; Gößling-Reisemann, Stefan; Lutz-Kunisch, Birgit (2010): Leitorientierte Technologie- und Systemgestaltung. In: Klaus Fichter, Arnim von Gleich, Reinhard Pfriem und Bernd Siebenhüner ( $\mathrm{Hg}$.): Theoretische Grundlagen für erfolgreiche Klimaanpassungsstrategien. Bremen: Projektkonsortium nordwest2050.

Heyen, Dirk; Brohmann, Bettina; Libbe, Jens; Riechel, Robert; Trapp, Jan (2018) Stand der Transformationsforschung unter besonderer Berücksichtigung der kommunalen Ebene. Berlin: Öko-Institut e. V.

Mielke, Jahel; Vermeßen, Hannah; Ellenbeck, Saskia; Fernandez Milan, Blanca (2016): Stakeholder involvement in sustainability science. A critical review. In: Energy Research \& Social Science 17, S. 71-81.

Nakićenović, Nebojsa (2000): Greenhouse gas emission scenarios. In: Technological Forecasting \& Social Change 65 (2), S. 149-166.

Rosenstiel, Lutz von (2007): Grundlagen der Organisationspsychologie. Stuttgart: Schäffer-Poeschel Verlag. 
Timpe, Christoph; Bauknecht, Dierk; Flachsbarth, Franziska; Koch, Matthias (2018): Transparenz Stromnetze. Stakeholder-Dialog und Modellierung zum Netzausbau und Alternativen. Berlin: Öko-Institut e.V.

Trutnevyte, Evelina; Barton, John; O'Grady, Aine; Ogunkunle, Damiete; Pudjianto, Danny; Robertson, Elisabeth (2014): Linking a storyline with multiple models. A cross-scale study of the UK power system transition. In: Technological Forecasting \& Social Change 89, S.26-42.

Weimer-Jehle, Wolfgang; Prehofer, Sigrid; Vögele, Stefan (2013): Kontextszenarien. Ein Konzept zur Behandlung von Kontextunsicherheit und Kontextkomplexität bei der Entwicklung von Energieszenarien. In: TATuP - Zeitschrift für Technikfolgenabschätzung in Theorie und Praxis 22 (2), S. 27-35. DOI: 10.14512/tatup.22.2.27.

Weimer-Jehle, Wolfgang (2006): Cross-impact balances. A system-theoretical approach to cross-impact analysis. In: Technological Forecasting \& Social Change 73 (4), S. 334-361.

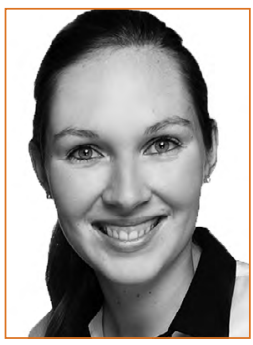

\section{RICARDA SCHMIDT-SCHEELE}

forscht am ZIRIUS zu Szenarien im Kontext von Energiewende und Nachhaltigkeit. Im Fokus ihrer Arbeit stehen Methoden der Erstellung, Wahrnehmung und Verarbeitung von Zukunftsperspektiven durch gesellschaftliche Akteure.

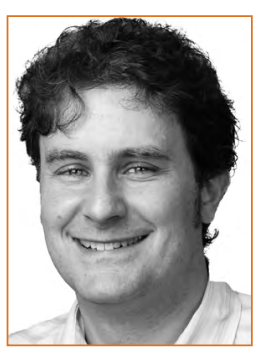

\section{DR. DIERK BAUKNECHT}

ist Senior Researcher im Bereich Energie \& Klimaschutz am Öko-Institut. Promotion an der University of Sussex mit einer Arbeit zu Stromnetztransformation. Er arbeitet zur Transformation des Stromsystems aus der Perspektive der Energiesystemanalyse als auch der Regulierung.
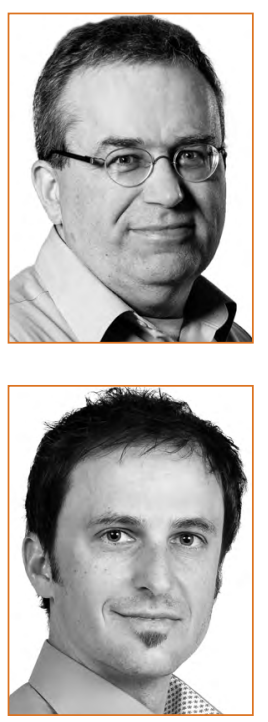

\section{DR. WITOLD-ROGER POGANIETZ}

ist promovierter Volkswirt und arbeitet am ITAS. Forschungsschwerpunkte sind die Analyse von sozio-technischen Treibern und Hemmnissen bei der Transformation von Energiesystemen in Europa und des "Globalen Südens".

\section{DOMINIK SEEBACH}

ist Geoökologe und Senior Researcher im Bereich Energie \& Klimaschutz am Öko-Institut. Er arbeitet zur Analyse politischer und ökonomischer Instrumente im Bereich der nachhaltigen Stromerzeugung und -nutzung.

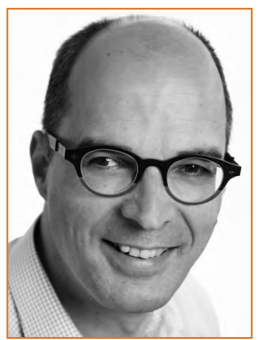

\section{CHRISTOF TIMPE}

ist Diplom-Ingenieur Energietechnik und Leiter des Bereichs Energie \& Klimaschutz am Öko-Institut. Er arbeitet zu nationalen und europäischen Strategien zur Entwicklung erneuerbarer Energien und zur nachhaltigen Transformation des Stromsystems in Deutschland und Europa.

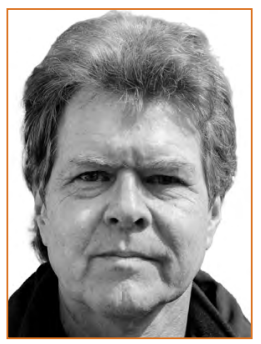

\section{DR. WOLFGANG WEIMER-JEHLE}

ist Physiker und forscht am ZIRIUS auf den Gebieten Energie, Nachhaltigkeit, Szenariomethodik und Methodenforschung zur qualitativen Systemanalyse. Schwerpunkt ist die Methodenforschung zur Cross-Impact-Bilanzanalyse, die von ihm entwickelt wurde.

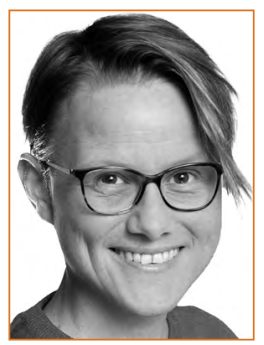

\section{DR. ANNIKA WEISS}

forscht als Ingenieurin am ITAS zu Energiesystemen. Schwerpunkt ist die Verknüpfung gesellschaftlicher und technischer Entwicklungen in Szenarien.

2016 erfolgte die Promotion zum Thema Energiebilanz von Mikroalgentreibstoff. Weitere Forschungsfelder sind Wasser und nachhaltige Transformation. 


\title{
Simulation von Innovationsdynamiken im Kontext der Energiewende
}

\author{
Beratungsorientierte Verbindung von Empirie und \\ sozialwissenschaftlichen simulationsmodellen
}

Joachim Globisch, Fraunhofer-Institut für System- und Innovationsforschung ISI, Breslauer Str. 48, 76139 Karlsruhe (joachim.globisch@isi.fraunhofer.de)

Bert Droste-Franke, IQIB - Institut für qualifizierende Innovationforschung und -beratung (bert.droste-franke@iqib.de)

Gabriele Fohr, IQIB - Institut für qualifizierende Innovationforschung und -beratung (gabriele.fohr@iqib.de)

Sandra Wassermann, Zentrum für interdisziplinäre Risiko- und Innovationsforschung (ZIRIUS), Universität Stuttgart (sandra.wassermann@zirius.uni-stuttgart.de)

Wie können Modelle zur Simulation von Akteursverhalten bei der Politikberatung zur Entwicklung von Maßnahmen zur Unterstützung der Genese und Diffusion nachhaltiger Technologien eingesetzt werden? Für Analysen zur Technologiegenese existiert bereits ein entsprechendes Simulationsmodell (SKIN). Mit Blick auf dieses Modell wird diskutiert, wie sich durch die Verbindung von Empirie und Simulation die Robustheit der Simulationsergebnisse steigern lässt. Für Akteursanalysen zur Technologiediffusion müssen entsprechende Simulationsmodelle erst noch entwickelt werden. Hierfür werden erste konzeptionelle überlegungen diskutiert.

\section{Simulation of innovation dynamics in the context of the energy transition \\ Advice-oriented combination of empirical and social science simulation models}

How can models for the simulation of actor behavior be used in policy advice on measures to support the development and diffusion of sustainable technologies? A corresponding simulation model already exists for analyses of technology development (SKIN). With reference to this model, it is discussed how the combination of empirical and simulation methods can increase the robustness of the simulation results. For actor analyses on technology diffusion, corresponding simulation models have yet to be developed. The article outlines some conceptual foundations for the development of such models.

Keywords: agent-based modeling, TIS analysis, empirical data, technology genesis, technology diffusion

This is an article distributed under the terms of the Creative Commons Attribution License CCBY 4.0 (https://creativecommons.org/licenses/by/4.0/)

https://doi.org/10.14512/tatup.28.3.34

Submitted: 08. 07.2019. Peer reviewed. Accepted: 24.10.2019

\section{Einleitung}

Im Zusammenhang mit der Energiewende bedarf es sowohl klassischer innovationspolitischer Maßnahmen zur Unterstützung der Technologiegenese als auch einer Förderung der Diffusion neuer Technologien (Weber und Rohracher 2012). Um die Effektivität solcher politischer Maßnahmen sicherzustellen, wird der Einsatz von Analyse- und Planungstools immer wichtiger. Im Bereich der Innovationspolitik bietet sich v. a. agentenbasierte Modellierung (ABM) als Simulationsinstrument an, um die Prozesse der Technologiegenese und -diffusion zu analysieren (s. hierzu auch TATuP 3/26 (2017)). Die Berücksichtigung von sozialwissenschaftlichen Ergebnissen in der Modellierung ist dabei von großer Bedeutung. So hängt z. B. die Diffusion neuer Energietechnologien stark von ihrer Akzeptanz durch Öffentlichkeit, potenzielle Nutzer*innen, Anwohner*innen, etc. ab (Wüstenhagen et al. 2007).

Dieser Artikel befasst sich daher mit methodischen Ansätzen, die die Evaluation von Politikmaßnahmen zur Förderung von Technologiegenese und -diffusion unter Berücksichtigung öffentlicher Unterstützung für diese Maßnahmen erlauben. Konzeptionelle Grundlage ist die Analyse Technologischer Innovationssysteme (TIS). Kerngedanke des TIS-Ansatzes ist, dass ein Innovationssystem aus Elementen (i.d. R. Organisationen, Institutionen, physische Infrastrukturen, Technologien) und Beziehungen zwischen den Elementen besteht (Hekkert und Negro 2011).

Nach Bergek et al. (2008) gliedert sich eine TIS-Analyse in sechs Schritte: (1) Definition des TIS, insbes. die „Flughöhe“ der Analyse (z. B. „Wärmepumpe“ vs. „Wärmetechnologien“); (2) Erfassung der drei übrigen zentralen Komponenten des TIS (Akteure, Netzwerke und Institutionen); (3) Analyse der Dynamik des TIS mit Blick auf sieben zentrale Funktionen (s. Tab. 1); 


\begin{tabular}{|c|c|}
\hline TIS-Funktion & Beschreibung \\
\hline 1. Unternehmerisches Experimentieren & Forschung, Anwendung, Testen und Kommerzialisierung von Wissen \\
\hline 2. Entstehung von Wissen & Lernen und schöpferische Anwendung von Wissen zur Entstehung neuen Wissens \\
\hline 3. Diffusion von Wissen & Austausch und Modifikation von Wissen \\
\hline 4. Suchrichtung & $\begin{array}{l}\text { Konvergenz der Zukunftsvorstellungen bzgl. Wachstum, technischer Entwicklung/Technikdesign } \\
\text { und übergeordneten Zielen des TIS }\end{array}$ \\
\hline 5. Ressourcenmobilisierung & Verfügbarkeit von Humankapital, politischer Unterstützung, finanziellem Kapital und Produktionsmitteln \\
\hline 6. Marktformierung & Herausbildung von Kundengruppen mit spezifischen Anforderungen und Kaufprozessen bzgl. des TIS \\
\hline 7. Legitimität & Unterstützung der neuen Technologie, Reduzierung von Unsicherheit \\
\hline
\end{tabular}

Tab.1: TIS-Funktionen.

Quelle: Eigene Darstellung nach Hekkert et al. 2007, Suurs 2009, Wieczorek et al. 2013, Bergek et al. 2008

(4) Einschätzung der Marktreife des TIS anhand der Dynamik der Funktionen; (5) Untersuchung von Anreiz- und Blockademechanismen (etwa durch etablierte Akteure und Technologien); (6) Ableitung von Handlungsempfehlungen aus den Schritten 1-5.

Obwohl die sieben Funktionen konzeptionell eine umfassende Charakterisierung eines TIS erlauben (s. Tab. 1), konzentrieren sich bisherige TIS-Analysen stark auf Untersuchungen zur Technologiegenese und damit auf die Funktionen 1 bis 3 . Um die Komplexität und Dynamik größerer gesellschaftlicher Transformationsprozesse bei TIS-Analysen besser zu verstehen, bedarf es einer stärkeren Berücksichtigung des Nachfragesystems sowie politischer und weiterer Akteure aus dem Umfeld des TIS (Weber und Rohracher 2012). Dazu kann konzeptionell an die Funktionen 4 bis 7 angeknüpft werden (vgl. Abb. 1).

So spiegelt die Funktion 6 „Marktformierung“ das Nachfragesystem, d.h. den Stand der Technologiediffusion, wider. Der Einfluss von Akteuren aus dem TIS-Umfeld kann über die Funktion 7 „Legitimität“ abgebildet werden, d.h. der Wahrnehmung und Unterstützung des TIS durch diese externen Akteure. Den Funktionen 4 ,Suchrichtung“ und 5 „,Ressourcenmobilisierung" kommt eine Brückenfunktion zwischen Technologiegenese und -diffusion zu: Je höher die Legitimität und je fortgeschrittener die Markformierung eines TIS ist, desto leichter können Ressourcen zu dessen (technologischer) Weiterentwicklung mobilisiert werden. Die Suchrichtung spiegelt die inhaltliche Konsolidierung eines TIS wider und steht in Wechselbeziehung zu den übrigen Funktionen. So fördert z. B. eine Konvergenz der Zukunftsvorstellungen zu einem TIS dessen Legitimität. Ähnliches gilt auch für die Zusammenhänge zwischen der Suchrichtung und den übrigen Funktionen.

Die beiden folgenden Kapitel knüpfen an diese Überlegungen zu den $\mathrm{Zu}-$ sammenhängen zwischen den TIS-Funktionen an. Im Kapitel Technologiegenese wird das Agentenmodell SKIN (Simula- ting Knowledge in Innovation Networks) vorgestellt. Hier wird erläutert, wie dieses Modell in Kombination mit empirischen Erhebungen zur Politikberatung mit Blick auf die Optimierung der drei Funktionen „Unternehmerisches Experimentieren“, „Entstehung von Wissen“ und „Diffusion von Wissen“ genutzt werden kann. Existierende Modelle zur Simulation der Technologiediffusion sind bisher techno-ökonomisch geprägt - Modelle zur Simulation von Akteursverhalten, müssen erst noch entwickelt werden. Daher befasst sich das Kapitel Technologiediffusion primär mit grundlegenden konzeptionellen Fragen zur Ausgestaltung eines solchen Akteursmodells und der Identifikation von Fragestellungen, zu deren Analyse sich das zu entwickelnde Akteursmodell in Kombination mit empirischen Erhebungen einsetzen lässt. Abschließend werden die Kernaussagen des Artikels zusammengefasst.

\section{Technologiegenese}

\section{Ansätze zur Simulation der Funktionen}

Um die zuvor dargestellten Funktionen bei der Technologiegenese simulieren zu können, wird das agentenbasierte Modell SKIN (Gilbert et al. 2010) herangezogen und um einige Funk-

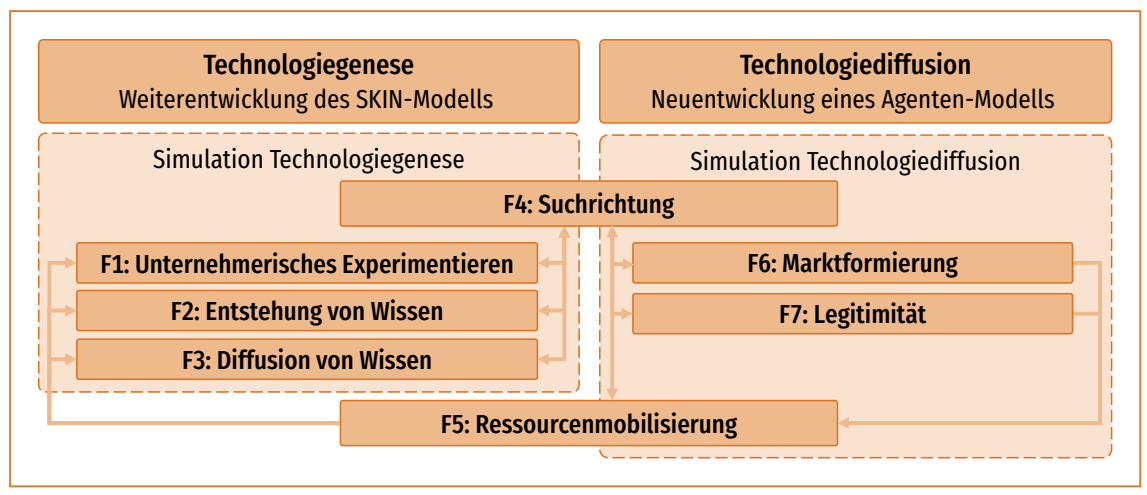

Abb.1: Zusammenhänge TIS-Funktionen, Technologiegenese und Technologiediffusion. 
tionalitäten erweitert, um es konkreter auf Technologieinnovationsprozesse anzupassen (Droste-Franke und Fohr 2017). Dieses wird im Folgenden ,erweitertes SKIN-Modell“ genannt.

Wissensgenese und -austausch sind zentrale Elemente von SKIN. In dem Modell interagieren Agenten mit heterogenen Eigenschaften in einer sich kontinuierlich verändernden Umgebung. Wissen kann entstehen aber auch vergessen werden und ein Produkt entsteht aus einer Kombination verschiedener Wissenskomponenten. Agenten im Modell sind vor allem Firmen und Forschungsinstitutionen, z. B. im Bereich der Entwicklung von Wärmepumpen. Firmen produzieren und verkaufen innova-

\section{Die Kombination von empirischen}

\section{Daten und ABM bietet mit Blick auf die Beratung zu möglichen Energiezukünften viele Vorteile.}

tive Güter, wie Wärmepumpen oder deren Vorprodukte. Dazu verwenden sie eigenes Wissen aber auch Wissen anderer Agenten. Dies umfasst zum einen Wissen aus Forschung und Entwicklung, aber auch praktisches Wissen für eine effiziente Produktion. Zum anderen werden geeignete Vorprodukte als Inputs anderer Agenten oder Ressourcen benötigt. Durch eigene Forschung und Forschung in Forschungsprojekten erhalten Firmen neues Wissen. Produktion und Forschung erhöht zudem die Expertise in vorhandenem Wissen. So können Wärmepumpen z. B. durch den Einsatz neuer Materialien oder eines neuen Designs effizienter gestaltet werden. Forschungsinstitutionen vermehren so ihr Wissen und tauschen es u. a. mit Firmen als Projektpartnern aus. Die Produkte werden auf dem Markt angeboten. Findet eine Wärmepumpe oder ein Vorprodukt keinen Absatz, senkt die Firma den Preis, forscht weiter oder wechselt das Produkt.

Um die Auswirkungen von Maßnahmen auf Struktur und Dynamik von Innovationsnetzwerken zu analysieren, werden diese im Rahmen von Simulationsexperimenten in SKIN implementiert. Maßnahmen können dabei direkt darauf abzielen, bestimmte Funktionalitäten des TIS zu verbessern. Eine Maßnahme könnte z. B. sein, die Zusammenarbeit und Kommunikation entlang der Wertschöpfungskette (z. B. zwischen Wärmepumpenherstellern und den Zulieferern) zu verbessern und damit den Wissensaustausch zwischen den jeweiligen Akteuren zu verstärken. Die TIS-Analyse kann dabei die Struktur vorgeben, in deren Rahmen Daten erhoben und Funktionalitäten bzgl. folgender Fragen bewertet werden: Ist eine geeignete Unternehmenslandschaft vorhanden um Wissensentstehung zu gewährleisten? Welche Arten von Wissen entstehen und wie wird Wissen ausgetauscht? Welche Hürden bestehen und wie können diese überwunden werden?

\section{Ansätze zur Verknüpfung von Empirie und Simulation}

Grundsätzlich kommen quantitative und qualitative Methoden der empirischen Innovationsforschung zum Einsatz, um mit SKIN realitätsnahe Abbildungen der Innovationsgenese zu ermöglichen. Einige empirisch erhobene Daten können direkt im Modell verwendet werden, z. B. empirische Ergebnisse zur Abstrahierung von Agenten und ihrer Umwelt, etwa indem die Anzahl von Patenten verschiedener Unternehmensklassen als Indikator für F \& E-Tätigkeiten mittels Patentanalyse zu Wärmepumpen erhoben werden. Solche Unternehmensklassen (z. B. nach Firmengrößen, Wirtschaftssektor, etc.) können dann als unterschiedliche Agententypen im Modell abgebildet werden. Informationen zur realen Zusammensetzung der Akteure eines TIS können aus Unternehmensstatistiken/-datenbanken gewonnen werden.

Zusätzlich zur Kalibrierung auf Mikroebene werden quantitative empirische Daten auf Meso- bzw. Makroebene herangezogen, mit denen sich die Ergebnisse der Modellierung vergleichen lassen. Durch Reproduktion beobachteter Strukturen in Innovationsnetzwerken, die sich etwa in beobachteten Forschungs- und Patentnetzwerken widerspiegeln, lässt sich die Validität des Modellierungsansatzes überprüfen.

Neben Ergebnissen aus quantitativen empirischen Analysen liefern auch qualitative Erhebungen wertvolle Informationen. Z. B. können in Interviews oder Workshops mit Wissenschaftler*innen und Praxisakteuren (1) die Funktionsmuster bei der Technologiegenese identifiziert, (2) die bisherige Funktionserfüllung bewertet, (3) Fragen an das Modell formuliert und (4) Modellergebnisse zur Ableitung von Handlungsempfehlungen diskutiert werden.

Tabelle 2 gibt einen Überblick über die Funktionen, die für die Technologiegenese besonders relevant sind sowie über Indikatoren und geeignete Datenquellen für empirische Erhebungen.

Im Modell sind des Weiteren allgemeinere Erkenntnisse über die Eigenschaften, Verhaltensweisen und strukturellen Rahmenbedingungen der handelnden Akteure abgebildet. Aus Studien ist beispielsweise bekannt, dass anwendbares Wissen je nach Kontext unterschiedlich intensiv ausgetauscht wird oder dass man Vorwissen in der Firma oder im Institut benötigt, etwa eine/n studierten Elektrotechniker*in, um bestimmtes Wissen aufnehmen und verwerten zu können. Auch die anderen Funktionen des TIS (s. u.) gehen u. a. so als Rahmenbedingungen ein.

\section{Simulationsexperimente mit SKIN zur Beratung}

Verschiedene Simulationsexperimente können mit dem Ziel der Beratung von (politischen) Entscheidungsträgern durchgeführt werden:

1. „Unternehmerisches Experimentieren“ ist im erweiterten SKIN durch Anwenden von Wissen zur Produktion von Gütern und durch die Gründung neuer Firmen auf verschiedene Weisen abgebildet. Der Erfolg wird durch die Erwirtschaftung von Erlösen abgebildet. Durch Simulationsexperimente können die Auswirkungen auf das Innovationssystem von Änderungen der Rahmenbedingungen für diese Aktivitäten 


\begin{tabular}{|c|c|c|}
\hline TIS-Funktion & Indikatoren/Event-/Ereignistypen & Daten/Datentypen, Quellen (Auswahl) \\
\hline $\begin{array}{l}\text { Unternehmerisches } \\
\text { Experimentieren }\end{array}$ & $\begin{array}{l}\text { Anzahl Akteure, Anzahl Unternehmen, Anzahl Entrepreneure, } \\
\text { neue Sparten etablierter Anbieter, Spezialisierung entlang } \\
\text { der Wertschöpfungskette }\end{array}$ & Unternehmens-, Branchenstatistik(en) \\
\hline Entstehung von Wissen & $\begin{array}{l}\text { Anzahl Patente, Publikationen, F \& E-Projekte, Forschungs- } \\
\text { intensität(en); Lernkurven }\end{array}$ & $\begin{array}{l}\text { Patent- und F \& E-Statistiken (EPO PatStat, Förderkatalog, } \\
\text { Wissenschaftsstatistik) }\end{array}$ \\
\hline Diffusion von Wissen & $\begin{array}{l}\text { Netzwerkgröße und -dichte, gemeinsame F \& E-Projekte, } \\
\text { gemeinsam gehaltene Patente, Zitationen, Workshops, Messen, } \\
\text { Konferenzen }\end{array}$ & $\begin{array}{l}\text { Patent- und F \& E-Statistiken, Mitglieder Branchenverbände, } \\
\text { Teilnehmer Konferenzen und Workshops }\end{array}$ \\
\hline Suchrichtung & $\begin{array}{l}\text { Anzahl und Gewicht wissenschaftlicher und journalistischer } \\
\text { Publikationen, Zielsetzungen, Regierungs- oder Förderprogramme }\end{array}$ & $\begin{array}{l}\text { H-Index von Publikationen, Patenten, Themen von Forschungs- } \\
\text { programmen }\end{array}$ \\
\hline
\end{tabular}

Tab.2: TIS-Funktionen und empirische Belege.

Quelle: Eigene Darstellung basierend auf Wieczorek et al. 2013, Hekkert et al. 2007

getestet werden, z. B. Zahl neuer Produkte bzw. Zahl von Start-ups verschiedener Typen.

2. „Die Entstehung von Wissen“ erfolgt im erweiterten SKIN durch Forschung und neue Akteure. Die Abbildung erfolgt durch einen evolutionären Prozess. Dem Wissen eines Akteurs ist immer auch eine Expertise zugewiesen. Diese erhöht sich für Wissen, das zur Produktion eingesetzt wird mit der Zahl der Produktionszyklen und bei Wissen, das in Projekte einfließt, mit seiner Verwendung in den Projekten. Entsprechend können mit dem Modell Auswirkungen von Änderungen in Rahmenbedingungen für unternehmerische und wissenschaftliche Forschung untersucht werden, die sich z. B. durch Schwerpunkte von Forschungsprogrammen ergeben.

3. Wissensaustausch zwischen den Akteuren erfolgt im erweiterten SKIN im Rahmen von bilateralen Zusammenarbeiten bei der Produktion, in Produktionsnetzwerken und bei Zusammenarbeiten in Forschungsprojekten. Dabei werden praktisches und wissenschaftliches Wissen unterschieden, Unterschiede in der Aufnahmemöglichkeit von Wissen abhängig vom Vorwissen berücksichtigt und Zuwachs von Expertise in verschiedenen Wissensbereichen modelliert, abhängig von der Menge des erhaltenen Wissens. Mit dem Modell können unter anderem Auswirkungen von Maßnahmen (wie spezifische Anreize zur Zusammenarbeit, Etablierung von Firmennetzwerken, Etablierung neuer Akteure mit entsprechenden Aufgaben und Veranstaltungsformaten, z. B. Energieagenturen) simuliert werden, die die Intensität des Wissensaustausches zwischen verschiedenen Akteuren (z. B. entlang/quer zur Wertschöpfungskette) oder die Erhöhung der Aufnahmefähigkeiten fördern.

4. Anleitung zur Suche ist im Modell nicht detailliert abgebildet, sondern durch Rahmenbedingungen vorgegeben. Eine Veränderung der Rahmenbedingungen, wie z. B. eine spezifischere Ausrichtung von Projektausschreibungen auf konkrete Wissensbereiche, führt über die Modelldynamik zu anderem Wissen, anderen Strukturen und Dynamiken. Auch Auswirkungen marktlicher Anreize über Nachfrage- oder Entwicklungs- und Produktionsförderung können im Modell simuliert werden.

\section{Technologiediffusion}

Für Analysen zur Technologiediffusion sind derzeit noch keine dem SKIN-Modell vergleichbaren Simulationstools vorhanden. Daher werden nachfolgend zunächst grundlegende konzeptionelle Aspekte der Frage adressiert, welche Aktivitäten von welchen Akteuren in Simulationstools zur Technologiediffusion abgebildet werden sollten, um einen Mehrwert bei der Politikberatung zu erbringen.

\section{Konzeptionelle Grundlage von Diffusionsanalysen}

Die Marktformierung in einem TIS kann als Ausdruck der Technologiediffusion betrachtet werden und Legitimität bildet für letztere eine zentrale Voraussetzung. Die Dynamik beider Funktionen hängt stark von Entscheidungen individueller Akteure ab: Konsument*innen treffen Kaufentscheidungen, in Unternehmen bedürfen neue Technologien der Unterstützung von sog. Innovation Champions (Globisch et al. 2018) und bei Politikmaßnahmen stellt sich die Frage nach der Akzeptanz von Bürger*innen sowie Betroffenen. Daher scheint eine Verbindung von TIS-Analyse und Akzeptanzforschung, die konzeptionell stärker auf die Analyse von individuellen Entscheidungen abzielt, sinnvoll. Hinsichtlich individueller Akteure können in Anlehnung an Wüstenhagen et al. (2007) drei Akzeptanzformen unterschieden werden (Bezug zu Abb. 2 jeweils in Klammern):

1. Sozio-politische Akzeptanz (I.): Die allg. Befürwortung oder Ablehnung von Technologien (z. B. Wärmepumpen) und Politikmaßnahmen (z. B. Verbote konventioneller Heizungen) durch die Wähler*innen.

2. Marktakzeptanz (II.): Die Adoption einer Technologie durch Entscheider*innen in Haushalten und Unternehmen als Nachfrager oder Investoren (z. B. Entscheidung für/gegen den Einbau einer Wärmepumpe).

3. Lokale Akzeptanz (III.): Die Reaktion von vor Ort konkret Betroffenen auf die Umsetzung von Adoptionsentscheidungen (z. B. Mieter*innen) und Politikmaßnahmen (z. B. Bauleitungen). 
F1-F3: Technologiegenese in Forschung und Angebotssystem

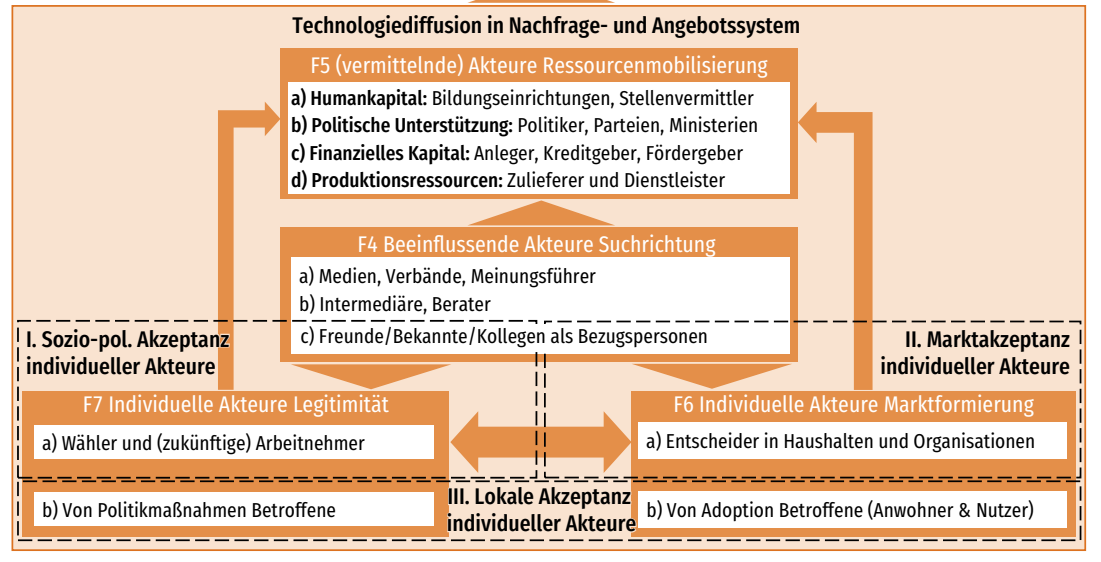

Abb.2: Technologiediffusion in Nachfrage- und Angebotssystem; Abweichungen zu Abb.1 ergeben sich aus dem primären Fokus auf individuelle Akteure.

Quelle: Eigene Darstellung in Anlehnung an Dütschke et al. 2019

von Legitimität $(\mathrm{F} 4 \mathrm{a} / \mathrm{b} \rightarrow \mathrm{F} 7)$ und Adoptionsentscheidungen $(\mathrm{F} 4 \mathrm{a} / \mathrm{b} \rightarrow \mathrm{F} 6)$ ?

Mit Blick auf die Ressourcenmobilisierung zur Unterstützung der Technologiegenese (F4 $\rightarrow$ F1-F3) lassen sich weitere Fragestellungen zum Einfluss individueller Akteure auf vermittelnde Akteure ableiten; z. B. welchen Einfluss hat die Legitimität eines TIS auf Studien- und Ausbildungsentscheidungen und die Ausgestaltung von Lehrplänen (z. B. Attraktivität von Bauingenieurs-Studiengängen mit Fokus auf Wärmepumpen/alternative Heiztechnologien; F7 a $\rightarrow$ F5 a)? Wie hängt die Legitimität eines TIS aus Sicht von Bürgern und Betroffenen mit der Positionierung von politischen Akteuren zusammen (F7a/b $\rightarrow$ F5b)? Inwieweit werden Entscheider bei potenziellen Kapitalgebern, Zulieferern und Dienstleistern in ihrer Wahrnehmung der TIS-Entwicklung auch durch persönliche Erfah-

\section{Fragestellungen an Diffusionsanalysen}

Ein Fokus auf individuelle Akteure führt zu einer entsprechenden Perspektive auf die Entstehung von Legitimität und Marktformierung, aus der sich unter anderem folgende Fragestellungen ergeben:

Entstehung Legitimität (F7): Unter welchen Voraussetzungen kann sich ein entstehendes TIS als förderungswürdige Alternative zu einem bestehenden TIS legitimieren, obwohl evtl. Nachteile hinsichtlich Kosten, Komfort, o. ä. bestehen (z. B. Wahrnehmung von Wärmepumpen als sinnvolles Element der Wärmewende; F7 a)? Welchen Einfluss hat die Legitimität auf die lokale Akzeptanz von Fördermaßnahmen für ein TIS (z. B. Akzeptanz von Vorschriften zur Heiztechnologie in Bebauungsplänen; F7 b)?

Dynamik Marktformierung (F6): Welchen Beitrag können Modelle zu Adopter-Gruppen (Rogers 2003) und psychologische Theorien zu individuellen (Adoptions-)Entscheidungen zu einem beratungsorientierten Verständnis der Markformierung leisten (z. B. Einflussfaktoren auf Beschaffung von Wärmepumpen; F6a)? Inwieweit sind Dritte von Adoptionsentscheidungen betroffen und spielen dadurch als Akteur*innen bei der Marktformierung eine Rolle (z. B. Akzeptanz von Umlage der Investitionskosten für eine neue Wärmepumpe durch die Mieter*innen; F6 b)?

Einfluss Suchrichtung (F4): Welchen Einfluss hat das persönliche Umfeld auf die Meinung von Bürger*innen (z. B. Einfluss von Meinungsführer*innen auf wahrgenommene Legitimität von Wärmepumpen ggü. anderen Heiztechnologien; F4 c $\rightarrow$ F7a) und potenziellen Adoptern (Einfluss von Bekannten auf wahrgenommene Attraktivität von Wärmepumpen ggü. anderen Heiztechnologien; F4c $\rightarrow$ F6a)? Welchen Einfluss haben gesellschaftliche Akteure und Intermediäre auf die Entstehung rungen mit einer Technologie (F6 $\rightarrow$ F5 c/d) oder persönliche Werte und Einstellungen (F7 $\rightarrow$ F5 c/d) beeinflusst?

\section{Mögliche empirische Grundlagen zur Simulation der Technologiediffusion}

Für die Untersuchung dieser Fragen können qualitative und quantitative Primärdaten erhoben werden. Weiterhin können auch Prozessdaten nützliche Datenquellen sein. So können bspw. Social-Media-Beiträge Einblicke in die Entstehung und Diffusion von Meinungen und Einstellungen erlauben. Darüber hinaus kann auch die Analyse von Medien-Berichten, Pressemitteilungen oder Parlamentsprotokollen u. ä. für die Identifikation und Positionsbestimmung der beeinflussenden gesellschaftlichen Akteure nützlich sein (Tab. 3). Solche Analysen können wiederum Ausgangspunkt für die Untersuchung des Einflusses dieser Akteure auf individuelle Einstellungen und Entscheidungen sein, die die Grundlage von Legitimität und Marktformierung bilden.

Zur Analyse der empirischen Daten können verschiedene Verfahren verwendet werden, die die Untersuchung unterschiedlicher Teilaspekte der genannten Forschungsfragen erlauben. Beispielhaft seien hier vier Verfahren genannt: (1) Strukturgleichungsmodelle zur Analyse des Zusammenspiels (psychologischer) Eigenschaften von Individuen und deren Einfluss auf die Akzeptanz von Maßnahmen und Technologien; (2) Choice- und Vignetten-Experimente zur Analyse des Einflusses der Eigenschaften von Technologien oder Maßnahmen auf deren Akzeptanz; (3) Clusteranalytische Verfahren zur Identifikation von Subgruppen (z. B. bei den Ergebnissen der zuvor genannten Verfahren); (4) (Egozentrische) Netzwerkanalysen zur Untersuchung der Struktur von interpersonellen Netzwerke und ihres Einflusses auf Einstellungen und Entscheidungen. 


\begin{tabular}{|c|c|c|}
\hline TIS-Funktion & Indikatoren/Event/Ereignistypen & Daten/Datentypen/Quellen (Auswahl) \\
\hline Suchrichtung & $\begin{array}{l}\text { Positionierung beeinflussender Akteure zu TIS Mobilisierungsfähigkeit beeinflussender } \\
\text { Akteure bzgl. TIS }\end{array}$ & \multirow{4}{*}{$\begin{array}{l}\text { - Bei Analysen zu beeinflussenden und vermit- } \\
\text { telnden (kollektiven) Akteuren: Text- und Social- } \\
\text { Discourse-Analyse von/mit Medienberichten, } \\
\text { Parlamentsprotokollen, Pressemitteilungen u. Ä. } \\
\text { - Qualitative Interviews, Gruppendiskussionen } \\
\text { und (Experten-)Workshops } \\
\text { - Quantitative Quer- und Längsschnitt- } \\
\text { befragungen (Auswertung z. B. mit u. g. Analyse- } \\
\text { methoden 1-4) } \\
\text { - Analyse von Inhalt und Zusammenhängen } \\
\text { von Social-Media-Beiträgen }\end{array}$} \\
\hline $\begin{array}{l}\text { Ressourcen- } \\
\text { mobilisierung }\end{array}$ & $\begin{array}{l}\text { Politische Unterstützung: Positionierung politischer Akteure im gesellschaftlichen } \\
\text { Diskurs zum TIS } \\
\text { Humankapital: Attraktivität des TIS für Arbeitnehmer*innen; TIS-bezogene } \\
\text { Bildungsangebote } \\
\text { Finanzielles Kapital und Produktionsmittel: Attraktivität des TIS als Geschäftsfeld }\end{array}$ & \\
\hline Marktformierung & $\begin{array}{l}\text { Marktakzeptanz: (Intention zu) Technologieadoption } \\
\text { Lokale Akzeptanz: Akzeptanz der Technologieadoption durch Betroffene }\end{array}$ & \\
\hline Legitimität & $\begin{array}{l}\text { Sozio-politische Akzeptanz: Positive Einstellung der Bürger*innen zu Technologie/TIS } \\
\text { Lokale Akzeptanz: Akzeptanz von Politikmaßnahmen durch Betroffene }\end{array}$ & \\
\hline
\end{tabular}

Tab.3: TIS-Funktionen und empirische Belege.

Quelle: Eigene Darstellung

\section{Verbindung von Empirie und Simulation}

Der Einsatz von ABM in Verbindung mit empirischen Analysen zur Untersuchung der genannten Forschungsfragen bietet sich v. a. aus zwei Gründen an:

1. Mit Blick auf die Beratung von (politischen) Entscheider*innen bietet der Einsatz von ABM vor allem den Vorteil, dass Szenarien zu möglichen Zukünften unter verschiedenen Annahmen simuliert und dadurch veranschaulicht werden können.

2. Im Rahmen einzelner empirischer Untersuchungen können stets nur Teilaspekte der Technologiediffusion adressiert werden. Durch den Einsatz von ABM können die Ergebnisse verschiedener empirischer Analysen zusammengeführt und so die Komplexität der Technologiediffusion besser berücksichtigt werden.

Damit eine Verbindung unterschiedlicher empirischer Untersuchungen mittels ABM gelingen kann, sind aber insbesondere zwei Herausforderungen zu bewältigen: (1) Damit Ergebnisse empirischer Analysen passfähig zur Struktur und Funk- nicht möglich. Daher bedarf es der (empirischen) Identifikation oder (zweckmäßigen) Definition von Subgruppen, über die die empirischen Ergebnisse unterschiedlicher Erhebungen den Agenten einer ABM zugeordnet werden können.

\section{Zusammenfassung und Schlussfolgerungen}

Aus den vorherigen Kapiteln wird deutlich, dass die Kombination von empirischen Daten und ABM mit Blick auf die Beratung $\mathrm{zu}$ möglichen Energiezukünften viele Vorteile bietet. ABM erlaubt die Simulation von Vorgängen in und zwischen Akteuren auf der Mikroebene und die Aggregation der Folgen dieser Vorgänge auf die Makroebenen. Durch die Simulation auf der Mikroebene kann die Beratung zu Politikmaßnahmen die (Heterogenität der) Entscheidungsprozesse von Adressaten und Stakeholdern berücksichtigen. Zugleich sind mittels Wenn-dann-Analysen Aussagen zu möglichen Folgewirkungen von unterschiedlich ausgeformten Politikmaßnahmen auf der Makroebene möglich. Darüber hinaus bietet die Simulation der

\section{ABM erlaubt die Simulation von Vorgängen in und zwischen Akteuren auf der Mikroebene und die Aggregation der Folgen dieser Vorgänge auf die Makroebenen.}

tionsweise einer ABM sind, sollten sich beide inhaltlich an den gleichen theoretischen Modellen orientieren. Dafür bedarf es möglichst universell anwendbarer theoretischer Modelle bzw. Meta-Modelle, die unterschiedliche theoretische Modelle miteinander verbinden. (2) Da in unterschiedlichen empirischen Untersuchungen auch unterschiedliche Personen befragt werden, ist eine Zusammenführung der Daten auf individueller Ebene
Interaktion zwischen verschiedenen Akteuren die Möglichkeit, auch nicht-intendierte Folgen einer Maßnahme zu erkennen, die sich aus zuvor nicht bedachten Reaktionen und Rückkopplungseffekten ergeben können.

Mit Blick auf die Kombination von Empirie und Simulation wurde gezeigt, wie verschiedene qualitative und quantitative Datenquellen (Tab. 2) zur Validierung und Kalibrierung des 
SKIN-Modells genutzt werden können, um robuste Systemanalysen zur Politikberatung zu ermöglichen. Zudem erlaubt die empirische Fundierung eine Simulation möglicher Entwicklungsverläufe, die einige Jahre in die Zukunft reichen. Durch die Berücksichtigung der Technologiediffusion und des gesellschaftlichen Umfelds eines TIS kann die Aussagekraft von ( $\mathrm{Si}$ mulations-)Ergebnissen zu möglichen Zukünften gesteigert werden. Auch hier bietet sich eine Kombination von Empirie und ABM als methodischer Ansatz zur Politikberatung an. Im $\mathrm{Zu}$ sammenhang mit der Analyse der Technologiediffusion sind die Entscheidungen individueller Akteure von besonderer Bedeutung, da sie der Entstehung von Legitimität, der Dynamik der Markformierung und der Mobilisierung wichtiger Ressourcen zugrunde liegen.

Die Verknüpfung beider Modelle und damit die Abbildung aller Funktionen des TIS stellt eine vielversprechende Möglichkeit dar, ein Innovationssystem in seiner Komplexität besser zu modellieren und zu untersuchen. Der Bedarf solcher kombinierten Analysen ergibt sich daraus, dass das Gelingen der Energiewende sowohl von der Dynamik technologischer Entwicklungen als auch von deren Akzeptanz abhängt.

\section{Literatur}

Bergek, Anna; Jacobsson, Staffan; Carlsson, Bo; Lindmark, Sven; Rickne, Annika

(2008): Analyzing the functional dynamics of technological innovation

systems. A scheme of analysis. In: Research Policy 37 (3), S. 407-429.

Dütschke, Elisabeth; Bögel, Paula; Choi, Su-Min; Globisch, Joachim; Burghard,

Uta (2019): Soziale Akzeptanz als erweitertes Verständnis des Akzeptanz-

begriffs. Eine Bestimmung der Akteure für den Prozess der Energiewende.

In: Akzeptanz und politische Partizipation in der Energietransformation.

Wiesbaden: Springer VS, S. 211-230.

Droste-Franke, Bert; Fohr, Gabriele (2017): Simulating innovation of key techno-

logies in German energy transition. Social Simulation Conference (SSC).

Dublin, Irland, 25-29.09.2017.

Gilbert, Nigel; Ahrweiler, Petra; Pyka, Andreas (2010): The SKIN (Simulating

Knowledge Dynamics in Innovation Networks) model. University of Surrey, University College Dublin, University of Hohenheim, https://github.com/ InnovationNetworks/skin, zuletzt geprüft am 23.10.2019.

Globisch, Joachim; Dütschke, Elisabeth; Wietschel, Martin (2018): Adoption of electric vehicles in commercial fleets. Why do car pool managers campaign for BEV procurement? In: Transportation Research Part D: Transport and Environment 64, S. $122-133$.

Hekkert, Marko; Negro, Simona (2011): Understanding technological change. Explanation of different perspectives on innovation and technological change. Utrecht University. Online verfügbar unter https://pdfs. semanticscholar.org/34c9/22f3580c98c2ccf50818a70525652fdd3b5e.pdf, zuletzt geprüft am 21.10.2019.

Hekkert, Marko; Suurs, Roald; Negro, Simona; Kuhlmann, Stefan; Smits, Ruud (2007): Functions of innovation systems. A new approach for analysing technological change. In: Technological Forecasting \& Social Change 74 (4), S. 413-432.

Suurs, Roald (2009): Motors of sustainable innovation. Towards a theory on the dynamics of technological innovation systems. Dissertation Utrecht University.
Weber, Matthias; Rohracher, Harald (2012): Legitimizing research, technology and innovation policies for transformative change. In: Research Policy 41 (6), S. 1037-1047.

Wieczorek, Anna; Negro, Simona; Harmsen, Robert; Heimeriks, Gaston; Luo, Lin; Hekkert, Marko (2013): A review of the European offshore wind innovation system. In: Renewable and Sustainable Energy Reviews 26, S. 294-306.

Wüstenhagen, Rolf; Wolsink, Maarten; Bürer, Mary (2007): Social acceptance of renewable energy innovation. An introduction to the concept. In: Energy Policy 35, S. 2683-2691.

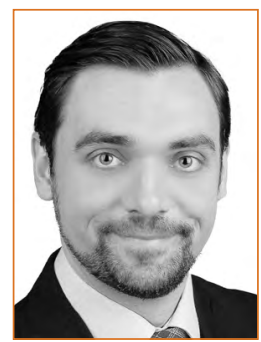

\section{DR. JOACHIM GLOBISCH}

forscht seit 2012 am Fraunhofer ISI zur Akzeptanz von Energietechnologien. Sein methodischer Schwerpunkt liegt auf quantitativen empirischen Untersuchungen und der Verbindung von Empirie und Modellierung.

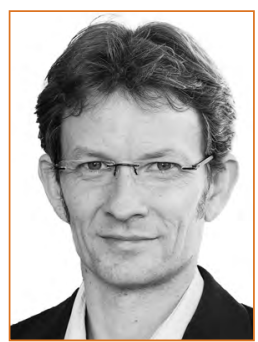

\section{DR. BERT DROSTE-FRANKE}

ist Head of Department Energy beim IQIB. Seine Schwerpunkte sind System-, Innovations- und Technikfolgenanalysen zur Entscheidungsunterstützung auf Basis theoretischer Arbeiten, inter-/ transdisziplinärer Expertengruppen, quantitativen Analysen und Modellierungen.

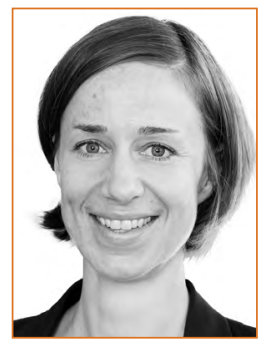

\section{GABRIELE FOHR}

ist wissenschaftliche Mitarbeiterin im Department Energy des IQIB. Ihr Hauptarbeitsfeld liegt in der Methodenentwicklung, vor allem für die Energiesystemanalyse, sowie in der Resilienzforschung.

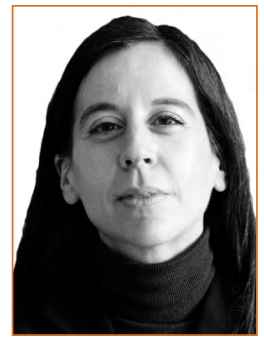

\section{SANDRA WASSERMANN}

ist bei ZIRIUS, Universität Stuttgart beschäftigt. Seit 2016 ist sie dort Sprecherin des Forschungsbereichs Energie. Ihr Forschungsinteresse gilt der Analyse von technologischen und sozialen Innovationen im Zuge der Energiewende. 


\section{Energiezukünfte für Power-to-X-Technologien \\ Eine Betrachtung der Akzeptabilität}

Julia Epp, Wissenschaftszentrum Berlin für Sozialforschung, Reichpietschufer 50, 10785 Berlin (julia.epp@wzb.eu)

Theresa Pfaff, Wissenschaftszentrum Berlin für Sozialforschung (theresa.pfaff@wzb.eu)

In Power-to-X-Technologien (P2X) in Form von synthetischen Kraft- und Brennstoffen für die Energie- und Verkehrswende werden große Hoffnungen gesetzt, ob als Lösung für den Umgang mit der Volatilität der erneuerbaren Energien oder als Kraftstoffe für den Verkehr. Aufgrund der begrenzten Flächen- und Erzeugungspotenziale erneuerbarer Energien ist jedoch kein großflächiger Ausbau von P2X-Anlagen in Deutschland zu erwarten. Der Import von P2X-Stoffen für die künftige Energieversorgung aus dem Ausland könnte eine wichtige Strategie zur Dekarbonisierung des Energiesystems sein. Die Akzeptabilität dieser Energiezukünfte wird hinsichtlich sozialer und ökologischer Kriterien exploriert.

\section{Energy futures for power-to-X technologies}

Reflection on the acceptability

Power-to-X technologies (P2X) in the form of synthetic fuels raise great hopes for the sustainable transition of the energy and mobility system: whether as a solution for handling volatile renewable energies or as green fuels for transport. Due to the limited land availability and production potential of renewable energies, however, a large-scale expansion of $P 2 X$ plants in Germany is unlikely. The import of $P 2 X$ products from abroad for local energy supply could be an important strategy to decarbonize the future energy system. The acceptability of these energy futures will be examined according to social and ecological criteria.

Keywords: power-to-X, energy transition, energy futures, synthetic fuels, acceptability

\section{Einleitung}

Durch die Energiewende soll der Transformationsprozess angestoßen werden, den die Menschheit benötigt, um aus energiewirtschaftlicher Sicht dem Klimawandel zu begegnen. Diese Transformation beinhaltet einen Übergang zu einer klimaverträg-

This is an article distributed under the terms of the Creative Commons Attribution License CCBY 4.0 (https://creativecommons.org/licenses/by/4.0/)

https://doi.org/10.14512/tatup.28.3.41

Submitted: 07. 07.2019. Peer reviewed. Accepted: 24.10.2019 lichen Gesellschaft, deren Kernstück die Dekarbonisierung des Energiesystems darstellt. Die deutsche Energiewende, welche bislang insbesondere als eine Stromwende beschrieben werden kann, steht nun vor den nächsten großen Herausforderungen. Zwar hat Deutschland einen Anteil von ca. 38\% erneuerbaren Energien in der Stromerzeugung erreicht, jedoch schaffen es die erneuerbaren Energien im Wärmesektor gerade einmal auf ca. $14 \%$ und im Verkehr nur auf ca. $6 \%$ (Umweltbundesamt 2019). Um signifikante Fortschritte bei der Dekarbonisierung dieser Sektoren zu erzielen, muss neben Sanierungsoffensiven, Energieeffizienzmaßnahmen und der Umstellung des Verkehrs vor allem der Ausbau der erneuerbaren Energien weiter vorangetrieben werden. Diese bilden die Basis des künftigen Energiesystems, weswegen der Strombedarf trotz Effizienzbemühungen in allen Sektoren steigen wird. Das bedeutet, dass Prozesse zunehmend elektrifiziert werden, zum Beispiel in der Industrie oder in Form von Elektromobilität und Stromwärmepumpen (Dena 2018).

Es eröffnet sich eine Bandbreite an Möglichkeiten, wie zum einem das erneuerbare Energiesystem künftig ausgestaltet sein wird und zum anderen, welche Transformationspfade unter Berücksichtigung verschiedenster Technologienkombinationen zu diesem Ziel führen. Neben direkten Elektrifizierungspfaden werden zunehmend Transformationspfade diskutiert, welche die Rolle von Power-to-X-Technologien (P2X) - also synthetische Kraft- und Brennstoffe - miteinbeziehen. P2X-Technologien ermöglichen es, aus Strom (Power) per Elektrolyseverfahren (to) andere Stoffe (X) herzustellen. Dabei wird üblicherweise zwischen Power-to-Gas (Wasserstoff und Methan), Power-to-Liquid (synthetische Kraftstoffe) und Power-to-Chemicals (chemische Grundstoffe) unterschieden ${ }^{1}$. P2X-Technologien befinden sich größtenteils noch in Pilot- und Demonstrationsphasen, ein globaler Markt für P2X-Stoffe hat sich noch nicht etabliert. Die Produktion und Nutzung von P2X-Stoffen auf Basis von erneuerbaren Energien in Deutschland und im Ausland wirft weitreichende Fragen auf, die im Rahmen dieses Beitrags genauer be-

1 Power-to-Heat und Power-to-Mobility werden als direkte Elektrifizierungspfade im Rahmen dieser Studie nicht als P2X-Produkte berücksichtigt, da es sich nicht um Wasserstoff-basierte Technologien handelt. 
leuchtet werden sollen. Energiezukünfte von P2X-Technologien werden derzeit insbesondere von Expert*innen bedient und bewegen sich in einem Spannungsfeld zwischen technischer Komplexität und hoher Unsicherheit hinsichtlich des Mengenbedarfs an P2X-Stoffen für die deutsche Energiewende. Im Vordergrund steht, welche Energiezukünfte für P2X-Technologien unter Berücksichtigung des aktuellen Wissenstandes bei Expert*innen der Wissenschaft, von Verbänden und Umweltschutzorganisationen existieren, welche Kriterien in Bezug auf die Akzeptabilität diskutiert werden und welche Fragen sich zu der zu erwartenden Akzeptanz ergeben.

\section{Hintergrund}

\section{Akzeptanz als Schlüsselfaktor der Energiewende}

Zwar ist die Zustimmung zur Energiewende über alle Altersgruppen und Bevölkerungsschichten in Deutschland mit 90\% hoch, jedoch formen sich gegenüber dem Ausbau von Windenergie-Anlagen immer mehr Proteste (Setton 2019). Dazu gehören lokale Bürgerinitiativen, die sich professionalisieren und mittlerweile überregional bzw. auch bundesweit vernetzen (Eichenauer 2018). Sollte der Ausbau der erneuerbaren Energie in Deutschland selbst stocken, dann gewinnen der europäische Stromhandel und Netzausbau zusätzlich an Bedeutung. Auch der Beitrag von P2X-Technologien muss in diesen Kontext gesetzt werden, da für deren nachhaltige Anwendung erneuerbare Energien zur Verfügung stehen müssen. Die große Schwachstelle bei der Produktion von P2X-Stoffen sind die weiteren Umwandlungsschritte und die damit verbundenen Effizienzverluste. Entsprechend bilden Akzeptanz und Akzeptabilität zwei wichtige Untersuchungsgegenstände.

Der Ausbau der erneuerbaren Energien ist allerdings Basis für alle weiteren Phasen der Energiewende, so auch der Nutzung von P2X-Technologien. Während Akzeptanz empirisch abgeleitet wird und sich mit der erwarteten Reaktion von bestimmten Akteuren auf eine Technologie beschäftigt (Beispiel: Nutzer*innen, Betroffene), betrachtet das Konzept der Akzeptabilität die generelle ethische und gesellschaftliche Rechtfertigbarkeit (Grunwald 2005, S. 55). Dieser theoretisch geleitete Diskurs bedient sich rationaler Kriterien - wie Grenzwerte der Emissionsbelastung und untersucht eine technische Entwicklung auf ihre Akzeptanzwürdigkeit und Zumutbarkeit hin (ebd., S. 55). Die Erkenntnisse zur Akzeptabilität sollten im Sinne eines transdisziplinären Vorgehens dazu verwendet werden, ,eine offene wissensbasierte und ethisch orientierte gesellschaftliche Diskussion“ zu führen (Grunwald 2003). In der folgenden Analyse wurden Aussagen aus einem interdisziplinären Umfeld zusammengetragen, welche Kriterien der Akzeptabilität von P2X-Technologien systematisieren.

\section{Energiezukünfte und Szenarien}

Grunwald (2005, S. 5) definiert Technikzukünfte als „Zukunftsvorstellungen, in denen projizierte wissenschaftlich-technische Entwicklungen in projizierte zukünftige gesellschaftliche For- mationen projiziert werden“. Generell können Technikzukünfte durch ein breites Spektrum an Methoden beschrieben werden. Dazu gehören Szenarien, Vorhersagen, Visionen, Roadmaps, Erzählungen und mehr. Deren Zweck ist es unter anderem, Transformationsprozesse zu strukturieren und diese so zu skizzieren, dass wichtige Entscheidungen bezüglich Investitionen, Technologieeinsatz oder politische Maßnahmen getroffen werden können (Grunwald 2011). Im Rahmen der Energiewende werden daher Szenarien oder Roadmaps entwickelt, um mögliche Transformationspfade zu konkretisieren und die daraus resultierenden zukünftigen Entwicklungen zu diskutieren. Im Kern sind Szenarien demgemäß Möglichkeitsaussagen, welche einen Ausschnitt der Wirklichkeit zu einem Zeitpunkt betrachten. Vorstellungen über die Zukunft existieren nicht per se, sondern werden in mehr oder weniger komplexen Prozessen sozial konstruiert. Entsprechend kann man Szenarien als eine Ausprägung von Energiezukünften verstehen, bei der das zu dem Zeitpunkt vorhandene Wissen über technologische Potenziale und normative Vorstellungen über das künftige Zusammenleben miteinfließen.

\section{Methodisches Vorgehen}

Aufgrund des neuartigen Charakters von P2X-Technologien und des Fokus auf die sich noch materialisierenden Energiezukünfte wurde ein exploratives Forschungsdesign gewählt, das die hinreichende Erforschung der Kriterien zur Akzeptabilität in den Vordergrund stellt. Die Auswahl von Studien zu P2X-Szenarien ${ }^{2}$ und Expert*innen erfolgte insbesondere basierend auf den Forschungsarbeiten der Roadmap des Kopernikus-Projekts „P2X“3, wobei die Roadmap zentrale Ergebnisse der interdisziplinären Forschung und politische Handlungsempfehlungen für die Energiewende zusammenfasst (Ausfelder und Dura 2018). Insgesamt wurden zehn einstündige Expert*inneninterviews mit Mitarbeitenden aus Institutionen der folgenden Bereiche geführt ${ }^{4}$ :

- Verbände $-1 \times$ Chemie (= Verband-C) und $1 \times$ Energie und Verkehr (= Verband-E \& V);

- Forschungseinrichtungen $-1 \times$ Verkehr (= Forschung-V), $3 \times$ Energie (= Forschung-E) und $1 \times$ Energie und Verkehr (= Forschung-E \& V);

- Umweltschutzorganisationen $-1 \times$ Verkehr (= Umweltschutz-V), $1 \times$ Energie (= Umweltschutz-E) und $1 \times$ Energie und Klimaschutz (= Umweltschutz-E \& K).

2 Literaturanalyse folgender Studien: Agora Verkehrswende, Agora Energiewende und Frontier Economics 2018; Altrock et al. 2018; Ausfelder und Dura 2018; Bazzanella et al. 2017; BDI 2018; Dena 2018; Frontier Economics 2018; UBA 2014; VNG 2018.

3 Das diesem Bericht zugrundeliegende Vorhaben wurde mit Mitteln des Bundesministeriums für Bildung und Forschung unter dem Förderkennzeichen 03SFK2N0 gefördert. Die Verantwortung für den Inhalt dieser Veröffentlichung liegt beim Autor

4 Erhebungszeitraum: April bis Juni 2019, aus Datenschutzgründen wurden die Institutionen der befragten Expert*innen anonymisiert. 


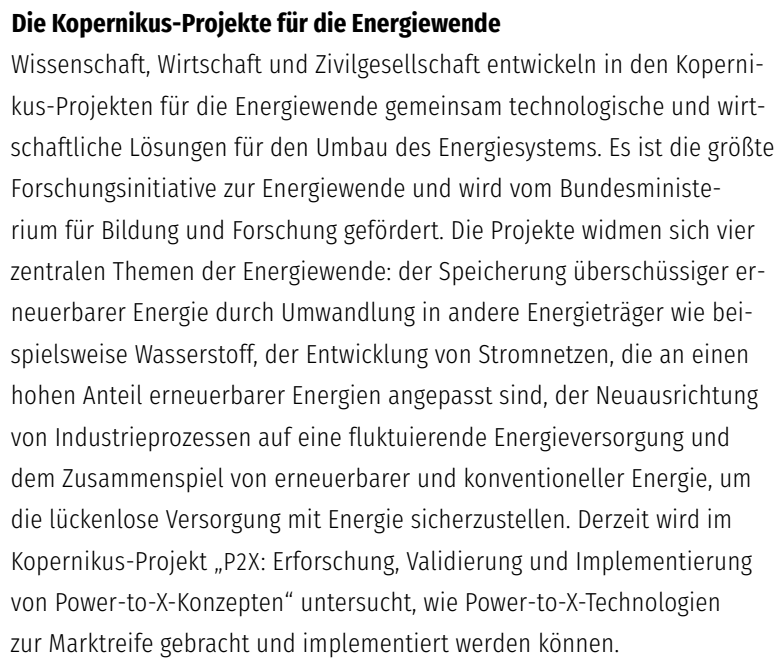

Die Auswertung erfolgt entsprechend der qualitativen Inhaltsanalyse nach Mayring (1991) mit dem Hintergrundwissen der theoretischen Einordnung und gemäß den Grundformen des Interpretierens: Zusammenfassung, Explikation und Strukturierung. Ziel ist es, Kriterien der P2X-Zukünfte und Akzeptabilität abzuleiten und zu diskutieren.

\section{Szenarien zu P2X und deren Akzeptabilität}

\section{Herleitung der P2X-Szenarien}

Ausgangspunkt für die Überlegungen zu Energiezukünften von P2X sind die im Kopernikus-Projekt diskutierten Annahmen und Perspektiven der Wissenschaft, Wirtschaft und Verbände. Dazu gehört vornehmlich die Betriebsweise von P2X-Anlagen, woran sich unmittelbar Standortfragen und sektorale Anwendungen anschließen. Dahingehend stellte die erste Roadmap des Kopernikus-Projekts P2X insbesondere zwei Betriebsweisen von $\mathrm{P} 2 \mathrm{X}$-Anlagen in den Vordergrund, aus denen sich die P2X-Szenarien ableiten (Ausfelder und Dura 2018, S. 55):

- Ein systemdienlicher Betrieb, der sich an der erneuerbaren Stromerzeugung orientiert, stabilisiert das Stromnetz und minimiert die Strombezugskosten für die P2X-Anlage.

- Ein kontinuierlicher Betrieb der Anlage führt zu möglichst hohen Volllaststunden und damit zu einer Minimierung der spezifischen Kapitalkosten für das Produkt.

\section{Netzdienliche Szenarien zu P2X}

In netzdienlichen Szenarien mit systemdienlicher Betriebsweise werden P2X-Anlagen angeschaltet, wenn ein starker „Überschuss" an erneuerbarem Strom in Deutschland produziert wird und am Erzeugungspunkt nicht ins Netz eingespeist werden kann. P2X-Anlagen würden Überkapazitäten bspw. von Wind- energieanlagen, die aufgrund von Netzengpässen abgeregelt werden müssten, nutzen und synthetische Stoffe produzieren. Die Anlagen würden in Deutschland aufgebaut und in dieser Betriebsweise nicht in Volllast laufen. In den Interviews wird betont, dass „Überschussstrom“ in Deutschland lediglich eine temporäre Verfügbarkeit von erneuerbaren Spitzenlasten darstellt, welche durch den weiteren Netzausbau und die Elektrifizierung des Verkehrs- und Wärmesektors abnehmen wird (Verband-C und Forschung-E\& V). Zwar wäre es wichtig, aktuell der Abregelung von Erneuerbare-Energien-Anlagen entgegen zu wirken, jedoch sollten in dieser Übergangsphase weitere Technologien der Sektorenkopplung und des Netzausbaus priorisiert werden, ohne ungewollte Pfadabhängigkeiten in Form von stationären $\mathrm{P} 2 \mathrm{X}$-Anlagen in Deutschland zu schaffen (Forschung-E\& V, Umweltschutz-E \& K).

Entsprechend sind sich die untersuchten Studien und Expert*innen uneins, welche Rolle die Produktion von Wasserstoff und anderen P2X-Stoffen in Deutschland spielen wird. Die Dena-Leistudie (2018) geht davon aus, dass im Jahr 2050 national zwischen 130 und 164 TWh pro Jahr an synthetischen Brennstoffen unter optimierter Nutzung von Einspeisespitzen erneuerbarer Energien erzeugt werden ${ }^{5}$. Im Gegensatz dazu sieht die Studie des BDI (2018) nur wenig wirtschaftliche Potenziale für die nationale Brennstoffproduktion aus „Stromüberschüssen“, da andere Flexibilitätsoptionen und Stromverbraucher die volatile Erzeugung in Zukunft ausgleichen werden. Zudem steigt der Einsatz von P2X-Technologien in Szenarien mit höheren Ambitionsniveau zur Treibhausgasreduktion (VNG 2018; Wietschel et al. 2018).

Grundlegend ist auch ein kontinuierlicher Betrieb von P2X-Anlagen in Deutschland denkbar. Allerdings fordern die interviewten Expert*innen, dass langfristig erneuerbare Energien in P2X-Anlagen zum Einsatz kommen sollten (Forschung-V, Forschung-E, Umweltschutz-E, Umweltschutz-E \& K). Die erneuerbaren Erzeugungskapazitäten sind bundesweit begrenzt: Erneuerbarer Strom wird auch in Zukunft ein knappes Gut sein und P2X-Technologien nutzen durch höhere Umwandlungsverluste den Strom weniger effizient als direkte Elektrifizierungsprozesse (Verband-C, Forschung-E \& V, Umweltschutz-E \& K). Vordergründig können aber durch die Realisierung von Pilotprojekten in Deutschland technisches Know-how und Erfahrungen in der Betriebsführung von P2X-Anlagen gesammelt werden. Dieses Wissen kann dann beim Aufbau von Anlagen im Ausland genutzt werden und Deutschland zu einer Technologieführerschaft verhelfen (Verband-C, Forschung-E). Regional kann die Produktion von Wasserstoff in Deutschland in begrenzten Maß sinnvoll sein, dies wird sich erst noch zeigen (Verband-E \& V, Umweltschutz-E). Beim Aufbau von P2X-Anlagen

5 Zum Vergleich: Im Jahr 2018 wurden insgesamt 427 Terawattstunden aus erneuerbaren Energien bereitgestellt, dies entspricht fast 17 Prozent des Endenergieverbrauchs in Deutschland. Von dieser Energiemenge entfielen etwa 53 Prozent (oder 225 TWh) auf die Stromproduktion, ca. 40 Prozent (oder 171 TWh) auf den Wärmesektor und etwa 7 Prozent auf biogene Kraftstoffe im Verkehrsbereich (32 TWh) (Umweltbundesamt 2019). 


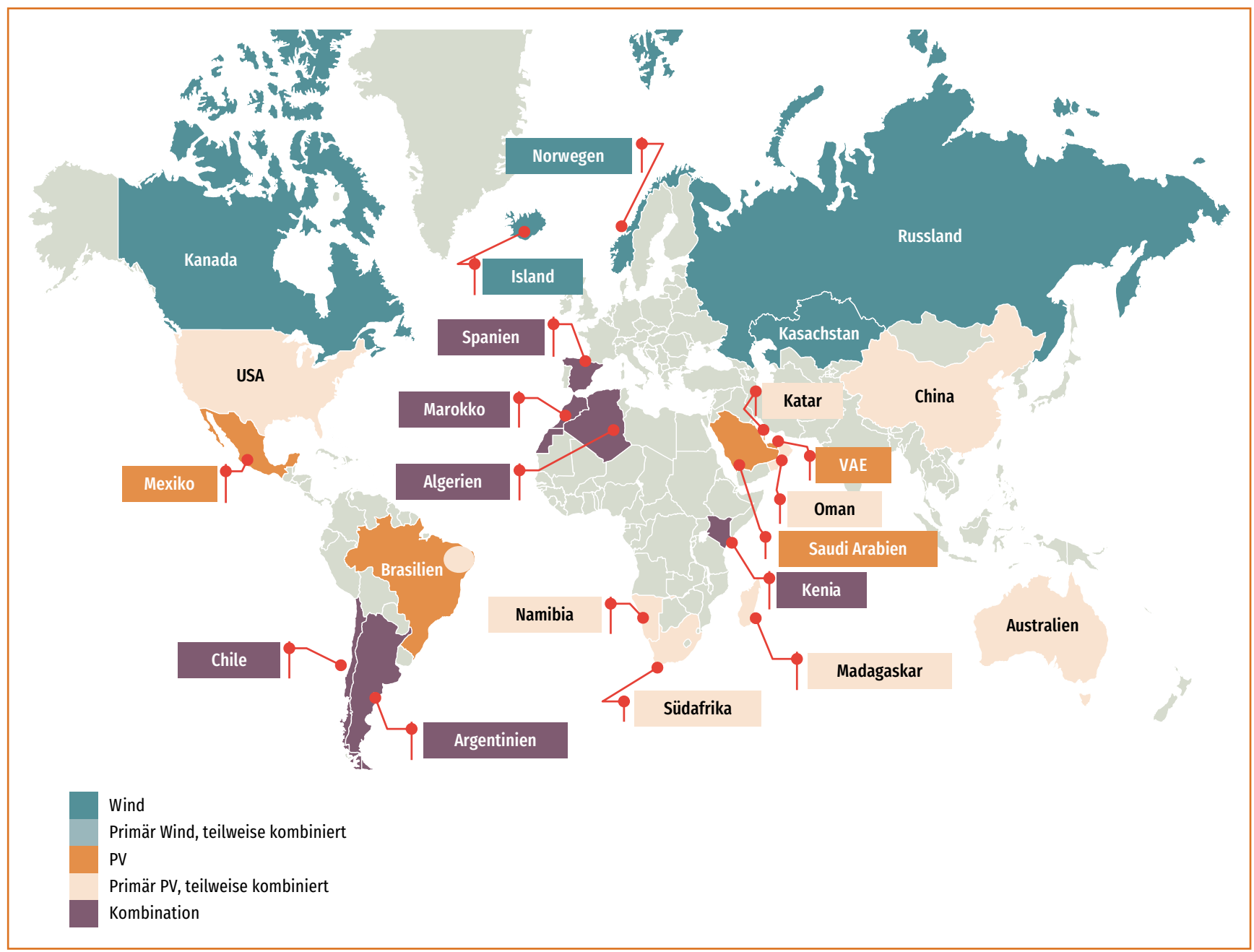

Abb. 1: Vielfalt und Diversität potenziell P2X produzierender Länder.

kann es wie beim Ausbau von Windenergieanlagen zu Widerständen und Akzeptanzproblemen kommen, die im regionalen Kontext erörtert werden müssen (Umweltschutz-E \& K).

\section{Remote-Szenarien zu P2X}

Remote-Szenarien legen den Fokus auf Standorte mit hohem Erzeugungspotenzial von erneuerbarem Strom, welche eine kontinuierliche Betriebsweise von P2X-Anlagen wirtschaftlicher machen würden ${ }^{6}$. In diesen Szenarien würde Deutschland P2XStoffe aus dem Ausland importieren. Für die Dekarbonisierung des chemischen Sektors wird eine kontinuierliche Betriebsweise von Anlagen für notwendig gehalten, da hohe Absatzmengen von P2X-Stoffen für den Ersatz von petrochemische Wertschöpfungskette benötigt werden (Verband-C, Forschung-E). Die analysierten Studien zeigen, dass Deutschland auch bei einer erfolg-

6 Eine systemdienliche Betriebsweise von P2X-Anlagen ist ebenso möglich, würde aber P2X-exportierende Länder wie im vorherigen Abschnitt vor die Problematik der Wirtschaftlichkeit unter geringeren Volllaststunden stellen. reichen Umsetzung der Energiewende weiterhin auf Energieimporte angewiesen sein wird, wenn auch in Summe in geringerem Maße als bisher. Der BDI-Studie (2018) zufolge sänken Energieimporte bis 2050 insgesamt um fast $80 \%$ gegenüber 1990 . Expert*innen der chemischen Industrie führen an, dass ihre Branche jedoch in den meisten Szenarien nicht berücksichtigt wird (Verband-C, Verband-E \& V). Die Menge an Importen synthetischer Energieträger hängt maßgeblich davon ab, inwieweit Onshore-Wind in Deutschland ausgebaut wird und wie erfolgreich sich der europäische Stromnetzausbau gestaltet.

Eine Importstrategie ist zudem voraussetzungsreich. So müssen hierfür verschiedene energiewirtschaftliche und infrastrukturelle Voraussetzungen geschaffen werden. Daneben hat eine solche Importstrategie auch weitreichende (geo-)politische Implikationen bspw. hinsichtlich der Interessen erdölproduzierenden Volkswirtschaften (siehe Abb. 1). Zahlreiche Kriterien können dem Import von P2X-Stoffen und damit dem Remote-Szenario zugrunde liegen (Forschung-V, Forschung-E, Öko-Institut 2019): Im Fokus steht vornehmlich das Kriterium der ,Strom- 
zusätzlichkeit‘, d. h. dass Länder sich erst selbst über alle Sektoren mit erneuerbaren Energien versorgen sollten, bevor sie für den Weltmarkt P2X-Stoffe produzieren. Darüber hinaus sollte im gesellschaftlichen Diskurs eruiert werden, inwieweit ,lokale Arbeitsbedingungen' bei der Produktion von erneuerbaren P2X-Stoffen für die deutsche Energieversorgung eine Rolle spielen (Forschung-V, Forschung-E, Umweltschutz-E \& K). Zusätzlich sollten weitere Untersuchungen zu Kriterien wie ,Flächeninanspruchnahme', $\mathrm{CO}_{2}$-Gewinnung als Rohstoff und ,Wasserbezug' in den Produktionsländern angestellt werden (Forschung-V, Forschung-E, Umweltschutz-E \& K). Insbesondere der die Vorstellung entstehen, dass ein disruptiver Wandel im Rahmen der Verkehrswende doch nicht nötig sei (Forschung-E \& V, Umweltschutz-E \& K). Teilweise wird in P2X-Technologien die Rettung des Verbrennungsmotors gesehen, denn grundsätzlich sei es möglich, P2X-Stoffe wie Methanol zu produzieren und diese im Verbrennungsmotor ohne größere Anpassungen zu nutzen (Verband-E\& V). Die interviewten Expert*innen sprechen sich für die Priorisierung von Batterieelektrischen Fahrzeugen im Pkw-Segment aus (Forschung-V, Forschung-E \& V, Forschung-E, Umweltschutz-V, Umweltschutz-E \& K). Der Ausbau von Schnellladestationen, die Kostendegression von Batte-

\section{Durch Pilotprojekte in Deutschland können Erfahrungen in der Betriebsführung von P2X-Anlagen gesammelt werden. Dieses Wissen kann dann beim Aufbau von Anlagen im Ausland genutzt werden.}

Wasserbedarf in Regionen wie Nordafrika könnte beim großtechnischen Ausbau von P2X-Anlagen zu Akzeptanzproblemen führen. In den Expert*inneninterviews wird auch das Kriterium politische Stabilität thematisiert, speziell bei der Produktion von P2X-Stoffen im außereuropäischen Raum (Verband-C, Forschung-E, Umweltschutz-V). Durch den Import synthetischer Gase kann vielen Herausforderungen, die mit der inländischen Herstellung verbunden sind, begegnet werden: Fragen zu begrenzten Ausbaupotenzialen der Windkraft, niedrigeren Volllaststunden der Anlagen oder des zusätzlichen inländischen Flächenbedarfs rücken in den Hintergrund.

\section{Akzeptanz und Diskurs um P2X-Szenarien}

\section{P2X als Hoffnungsträger}

Die Energiewende hat eine Phase erreicht, in der die nächsten Schritte der Sektorenkopplung vorangetrieben werden müssen. Im Vergleich der Szenarien zeichnen sich die verschiedenen Blickwinkel der Expert*innen auf P2X-Technologien ab: Während Akteure aus dem Energiesektor (Anlagenbetreiber, Netzbetreiber etc.) eher mit der Brille des volatilen Angebotes auf die Möglichkeiten von P2X zur Netzstabilität schauen, streben Akteure aus der chemischen Industrie oder dem Verkehrssektor auf der Nachfrageseite eine gesicherte Versorgung mit P2X-Stoffen an (Verband-C, Forschung-E, Umweltschutz-E \& K). Diese Sichtweisen zusammenzuführen, stellt im aktuellen Diskurs eine wesentliche Herausforderung dar, da der Einsatz von P2X-Technologien unter verschiedenen Betriebsweisen und Standorten erfolgen würde.

Die Gemengelage für den Verkehrssektor gestaltet sich beispielsweise äußerst komplex. Es kann hier bei einigen Akteuren rien und die steigende Reichweite von Fahrzeugen machen die Batterieelektrische Mobilität zunehmend attraktiver. Im Fern-, Schwerlast und im öffentlichen Personenverkehr ist offen, welche technologischen Optionen überwiegen werden (Wasserstoff, Power-to-Liquid, E-Mobilität mit Oberleitungen etc.). Bei Schiffen und Flugzeugen wird eine Dominanz von synthetischen Kraftstoffen und Biokraftstoffen gesehen (VNG 2018; Forschung-V, Umweltschutz-V). Der Verkehrssektor benötigt allerdings nicht nur eine Energiewende im Verkehr, sondern auch eine Mobilitätswende. Das heißt, dass multimodales Verkehrsverhalten und klimafreundliche Fortbewegungsmittel priorisiert und gefördert werden müssen, um u.a. von der autogerechten zur lebenswerten Stadt zu kommen (Debatte der „Flächengerechtigkeit“, Canzler und Knie 2019). Die soziale Konstruktion von P2X-Energiezukünften unterliegt deshalb im Speziellen der Gefahr, die Technologien als einfache Lösung zu propagieren. P2X als Bestandteil der Energie- und Verkehrswende bedingt allerdings einen massiven Ausbau an erneuerbaren Erzeugungsanlagen.

\section{Szenarien und ihr Diskursbeitrag}

Das große Potenzial von Energiezukünften liegt darin, den komplexen Baustein der P2X-Technologien in der Energiewende zu veranschaulichen (Verband-E \& V, Forschung-V, Forschung-E, Umweltschutz-V, Umweltschutz-E). Energieszenarien verlangen ihren Rezipienten ab, dass sie die Implikationen der dort dargestellten Szenarien verstehen und einordnen können. Ein Problem der aktuellen P2X-Energiezukünfte ist sicherlich, dass diese bisher vor allem in der Wissenschaft, Politik und Wirtschaft diskutiert werden. Außerdem werden P2X-Technologien der breiten Bevölkerung unbekannt sein und müssen aufgrund der technischen Komplexität in ein zielgerichtetes und konsistentes Nar- 
rativ eingebettet werden. Es ist nun Aufgabe der transdisziplinären Forschung, in einen deliberativen Diskurs zu treten, um diskursmächtige Akteure, Verbraucher*innen und Produzent*innen aber auch die allgemeine Bevölkerung in die weitreichenden Entscheidungen der Energiewende miteinzubeziehen. Kritisch ist es jedoch, wenn Energiezukünfte Einfluss auf die Diskurse nehmen, weil sie von bestimmten Akteuren als Fakten darge- mechanismen - dies alles charakterisiert disruptive Transformationsprozesse, und dies alles ist konfliktträchtig. Diese Herausforderungen transparent zu machen und in einem gesellschaftlichen Aushandlungsprozess zu lösen, muss zur Gewährleistung der Akzeptanz von P2X-Technologien passieren.

Derzeit werden P2X-Zukünfte vornehmlich von Wissenschaft und Wirtschaft gestaltet, obwohl Verbände und zivilge-

\section{Die Gemengelage für den Verkehrssektor gestaltet sich äußerst komplex.}

stellt werden, um damit Entscheidungen zu legitimieren (Verband-E \& V, Forschung-E \& V, Forschung-E, Umweltschutz-V). Bei Remote-Szenarien sollten die geopolitischen, sozialen und ökologischen Auswirkungen transparent gemacht werden. Ähnlich wie beim Biodiesel besteht hier die Gefahr, dass die ,Teller vs. Tank'-Debatte zu einer, Wasser vs. Tank'-Debatte wird. Die identifizierten Kriterien für den Import von P2X-Stoffen aus dem Ausland und den netzdienlichen Betrieb von P2X-Anlagen können nur in einem gesellschaftlichen Diskurs auf ihre Akzeptabilität geprüft werden. Für die Bevölkerung muss der angestrebte Wandel annehmbar gemacht (Akzeptanz), Zustimmung durch einen transparenten Diskurs geschaffen (Legitimation) und Teilhabe ermöglicht werden (Partizipation) (WGBU 2011).

\section{Fazit}

Die Hoffnungen und Vorstellungen zu P2X-Technologien sind komplex und teilweise widersprüchlich. Im Fokus des aktuellen Diskurses stehen netzdienliche und Remote-Szenarien, welche nicht per se miteinander konkurrieren, jedoch von unterschiedlichen Akteuren mit ungleichen Sichtweisen bespielt werden. Es wird deutlich, dass in netzdienlichen Szenarien die nationalen Potenziale der P2X Produktion aufgrund der Sektorenkopplung eher gering bleiben werden (Elektromobilität, Wärmepumpen, etc.). In Hinblick auf Remote-Szenarien ist ungewiss, in welchen Regionen unter welchen Bedingungen P2X-Stoffe für die deutsche Energieversorgung produziert werden können. Für die nachhaltige Bereitstellung der Stoffe müssen Kriterien wie die Stromzusätzlichkeit, Arbeitsbedingungen, Flächenanspruch, Wasserbezug und politische Stabilität/Rechtsicherheit berücksichtigt und transdisziplinär diskutiert werden.

Aus sozialwissenschaftlicher Sicht ist klar, dass solche Transformationsprozesse, wie sie in der Energiewende stattfinden, stets mit Konflikten behaftet sind. Die Einführung neuer technischer Systeme, ihre Einbettung in neue Nutzungsroutinen, die Auflösung früherer oder konkurrierender Systeme, die Restrukturierung von Unternehmen und Märkten, die parallel verlaufende Herausbildung von neuen politischen Steuerungs- sellschaftliche Organisationen sich zunehmend in den Diskurs einbringen. Die hohen Unsicherheiten und das geringe Wissen zu der Rolle von P2X-Technologien für die Energiewende eröffnet die Möglichkeit, dass Expert*innen den Diskurs durch ein aktives Gestalten und Propagieren ihrer Vorstellungen zu P2X bestimmen. Im Verkehrssektor und in der chemischen Industrie als Hauptabnehmer von P2X-Stoffen müssen aber neben technologischen Veränderungen auch ein systematischer Wandel in Richtung Mobilitätswende und Circular Economy erfolgen. Szenarien und Kriterien der Akzeptabilität sind dabei hilfreiche Werkzeuge, Transformationen in ihren möglichen Entwicklungspfaden zu veranschaulichen und gesamtgesellschaftlich zu verorten.

\section{Literatur}

Agora Verkehrswende; Agora Energiewende; Frontier Economics (2018): Die zukünftigen Kosten strombasierter synthetischer Brennstoffe. Online verfügbar unter https://www.agora-verkehrswende.de/fileadmin/Projekte/2017/ Die_Kosten_synthetischer_Brenn-_und_Kraftstoffe_bis_2050/Agora_Kosten_ strombasierter_Brennstoffe_WEB.pdf, zuletzt geprüft am 27.09.2019.

Altrock, Martin et al. (2018): Rechtliche Rahmenbedingungen für ein integriertes Energiekonzept 2050 und die Einbindung von EE-Kraftstoffen. Online verfügbar unter https://www.bmvi.de/SharedDocs/DE/Anlage/G/MKS/iek-2050. pdf?__blob=publicationFile, zuletzt geprüft am 25. 06.2019.

Ausfelder, Florian; Dura, Hanna (Hg.) (2018): Optionen für ein nachhaltiges Energiesystem mit Power-to-X-Technologien. Herausforderungen - Potenziale - Methoden - Auswirkungen. 1. Roadmap des Kopernikus-Projektes „Power-to-X“. Frankfurt am Main: DECHEMA. Online verfügbar unter https:// dechema.de/dechema_media/Downloads/Positionspapiere/2018_Power to_X-p-20003687.pdf, zuletzt geprüft am 20.09.2019.

BDI - Bundesverband der Deutschen Industrie (2018): Klimapfade für Deutschland. Online verfügbar unter https://e.issuu.com/embed. html\#2902526/57478058, zuletzt geprüft am 13.06.2019.

Canzler, Weert; Knie, Andreas (2019): Strategiepapier Autodämmerung. Experimentierräume für die Verkehrswende. Berlin: Heinrich-Böll-Stiftung. Online verfügbar unter https://www.boell.de/sites/default/files/ strategiepapier_verkehrswende.pdf?dimension1=division_sp, zuletzt geprüft am 27. 09.2019.

Bazzanella, Alexis; Ausfelder, Florian; DECHEMA - Gesellschaft für Chemische Technik und Biotechnik e. V. (2017): Technology study. Low carbon energy and 
feedstock for the European chemical industry. Frankfurt am Main: DECHEMA. Online verfügbar unter https://dechema.de/dechema_media/Downloads/ Positionspapiere/Technology_study_Low_carbon_energy_and_feedstock_ for_the_European_chemical_industry-p-20002750.pdf, zuletzt geprüft am 11.06.2019.

Dena (2018): dena-Leitstudie Integrierte Energiewende. Impulse für die Gestaltung des Energiesystems 2050. Online verfügbar unter https://www.dena. de/fileadmin/dena/Dokumente/Pdf/9262_dena-Leitstudie_Integrierte_ Energiewende_Ergebnisbericht.pdf, zuletzt geprüft am 20.09.2019.

Eichenauer, Eva; Reusswig, Fritz; Meyer-Ohlendorf, Lutz; Lass, Wiebke (2018): Bürgerinitiativen gegen Windkraftanlagen und der Aufschwung rechtspopulistischer Bewegungen. In: Olaf Kühne und Florian Weber (Hg.): Bausteine der Energiewende. Wiesbaden: Springer Fachmedien, S. 633-651.

Frontier Economics (2018): International Aspects of a Power-to-X Roadmap. Berlin: Weltenergierat. Online verfügbar unter https:// www.weltenergierat. de/wp-content/uploads/2018/10/20181018_WEC_Germany_PTXroadmap_ Full-study-englisch.pdf, zuletzt geprüft am 11.06.2019.

Grunwald, Armin (2003): Eine Stellungnahme aus Sicht der klassischen Technikfolgenabschätzung. In: Susanne Giesecke (Hg.): Technikakzeptanz durch Nutzerintegration. Beiträge zur Innovations- und Technikanalyse. Teltow: VDI/VDE Technologiezentrum Informationstechnik GmbH, S. 113-125.

Grunwald, Armin (2005): Zur Rolle von Akzeptanz und Akzeptabilität von Technik bei der Bewältigung von Technikkonflikten. In: TATuP - Zeitschrift für Technikfolgenabschätzung in Theorie und Praxis 14 (3), S. 54-60. Grunwald, Armin (2011): Energy futures: Diversity and the need for assessment. In: Futures 43 (8), S. 820-830. DOI: 10.1016/j.futures.2011.05.024.

Mayring, Philipp (1991): Qualitative Inhaltsanalyse. In: Uwe Flick, Ernst von Kardoff, Heiner Keupp, Lutz von Rosenstiel und Stephan Wolff (Hg.): Handbuch qualitative Forschung. Grundlagen, Konzepte, Methoden und Anwendungen. München: Beltz- Psychologie Verl. Union, S. 209-213.

Öko-Institut (2019): Kein Selbstläufer. Klimaschutz und Nachhaltigkeit durch PtX. Diskussion der Anforderungen und erste Ansätze für Nachweiskriterien für eine treibhausgasfreundliche und nachhaltige Produktion von PtXStoffen. Impulspapier im Auftrag des BUND im Rahmen des KopernikusVorhabens „P2X“. Potsdam: Öko-Institut. Online verfügbar unter https://www.oeko.de/fileadmin/oekodoc/Impulspapier-soz-oek-Kriteriene-fuels.pdf, zuletzt geprüft am 27.09.2019.

Setton, Daniela (2019): Soziales Nachhaltigkeitsbarometer der Energiewende 2018. Kernaussagen und Zusammenfassung der wesentlichen Ergebnisse. Potsdam: Institut für transformative Nachhaltigkeitsforschung (IASS). Online verfügbar unter https://www.iass-potsdam.de/sites/default/files/2019-02/IASS_ Nachhaltigkeitsbarometer.pdf, zuletzt geprüft am 27.09.2019.

Umweltbundesamt (2014): Treibhausgasneutrales Deutschland im Jahr 2050. Online verfügbar unter https://www.umweltbundesamt.de/sites/default/ files/medien/378/publikationen/07_2014_climate_change_dt.pdf, zuletzt geprüft am 21.10.2019.

Umweltbundesamt (2019): Erneuerbare Energien in Zahlen. Online verfügbar unter https://www.umweltbundesamt.de/themen/klima-energie/ erneuerbare-energien/erneuerbare-energien-in-zahlen\#statusquo, zuletzt geprüft am 15. 06.2019.

VNG (2018): META-Studie Sektorenkopplung. Analyse einer komplexen Diskussion. Online verfügbar unter https://vng.de/sites/default/files/vng_meta_studie_ sektorenkopplung_enervis.pdf, zuletzt geprüft am 13.06.2019.

WBGU - Wissenschaftlicher Beirat der Bundesregierung Globale Umweltveränderungen (2011): Welt im Wandel. Gesellschaftsvertrag für eine Große Transformation. Berlin: Wissenschaftlicher Beirat der Bundesregierung Globale Umweltveränderungen (WBGU). Online verfügbar unter https://issuu. com/wbgu/docs/wbgu_jg2011?e=37591641/69400318/, zuletzt geprüft am 21. 10.2019.

Wietschel, Martin; Oberle, Stella; Ashley-Belbin, Natalja (2018): Power-to-X. Potenziale und Handlungsempfehlungen. Kurzgutachten im Auftrag der Impuls Stiftung, Frankfurt am Main. Online verfügbar unter: http://P2X4a. vdma.org/documents/27093545/27689039/IMPULS-Studie\%20P2X_2018-1211_1544780170056.pdf/7fca7c5e-c124-862f-2eaf-00acd5a0817b, zuletzt geprüft am 26.09.2019.
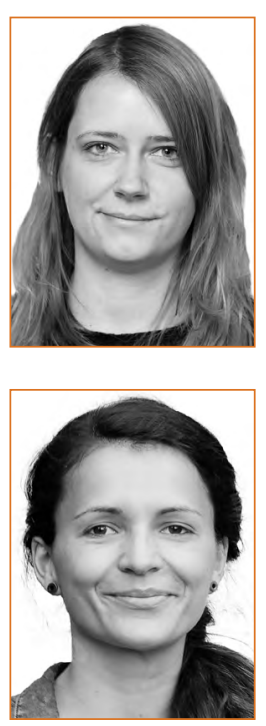

\section{JULIA EPP}

ist seit 2018 wissenschaftliche Mitarbeiterin am Wissenschaftszentrum Berlin für Sozialforschung und arbeitet im Kopernikus-Projekt „P2X“. Im Rahmen ihrer Doktorarbeit beschäftigt sie sich mit den sozialen und politischen Dimensionen der Sektorenkopplung.

\section{THERESA PFAFF}

ist seit 2019 Mitarbeiterin am Wissenschaftszentrum Berlin für Sozialforschung. Sie arbeitet im Kopernikus-Projekt „P2X“ vor allem zu kommunikativen Aspekten von technologischen Entwicklungen. 


\title{
Quo vadis, Energiewenderecht?
}

\author{
Energierechtliche Zukunftsgestaltung
}

Michael Kalis, IKEM - Institut für Klimaschutz, Energie und Mobilität e.V., Magazinstraße 15-26, 10179 Berlin (michael.kalis@ikem.de)

Lars Dittmar, IKEM - Institut für Klimaschutz, Energie und Mobilität e. V. (lars.dittmar@ikem.de) @10 orcid.org/0000-0003-4949-6273

Die Energiewende betrifft als Transformationsprozess eine Vielzahl von Beteiligten: Unternehmen, Forschung, Verbraucher*innen und den Gesetzgeber. Letzterer kann ein erheblicher Treiber oder ein vehementer Bremser der Energiewende sein. Das Energiewenderecht entscheidet maßgeblich über das Gelingen oder Misslingen der Energiewende und ist damit Teil der energierechtlichen Zukunftsgestaltung. Diese Energiezukunft braucht technologische, ökonomische und regulatorische Innovationen. Angesichts des schwierigen Umgangs mit Innovationen steht der Gesetzgeber vor besonderen Herausforderungen. Zur Bewältigung dieser hat er einen breiten Instrumentenkanon zur Verfügung. Im Fokus stehen derzeit unter anderem sogenannte Experimentierklauseln. Ob das Energiewenderecht hiermit auf die Technologien und Geschäftsmodelle der Zukunft vorbereitet ist, untersuchen die Autoren in diesem Aufsatz.

\section{Quo vadis, energy transition law?}

Shaping the future energy system

As a transformation process, the energy transition involves a variety of actors: enterprises, science, consumers, and the legislator. The latter can be a major driver or inhibitor of the energy transition. The energy transition law is decisive for the success or failure of the energy transition and plays a part in shaping the future energy system. This energy future requires technological, economic, and regulatory innovations. Given the complexity of innovations, the legislator faces special challenges. It has a wide range of legal instruments at its disposal to deal with these challenges. A current focus is on so-called experimentation clauses. In this article, the authors examine whether these instruments are sufficient to prepare the energy transition law for the technologies and business models of the future.

Keywords: innovation, deregulation, experimental rule, carbon pricing

\section{Entwicklungen des Energiewenderechts}

Das erste Energiewirtschaftsgesetz (EnWG) aus dem Jahr 1935 überdauerte - in seiner wesentlichen Ausgestaltung - mehr als 60 Jahre und wurde erst im Zuge der Umsetzung der EU-Binnenmarktrichtlinie 1996 mit dem Gesetz zur Neuregelung des Energiewirtschaftsrechts aus dem Jahr 1998 abgelöst. Das EnWG 1998 legte dabei nicht nur den Grundstein zur Liberalisierung der leitungsgebundenen Versorgung mit Erdgas und Elektrizität, sondern erklärte auch erstmals Umweltverträglichkeit als energiepolitische Zielsetzung im $\S 1$ des EnWG. Hiermit wurden die seit dem ersten EnWG aus dem Jahr 1935 geltenden Ziele, Versorgungssicherheit und Preisgünstigkeit, durch Hinzunahme von Umweltverträglichkeit zum heute noch gültigen energiepolitischen Zieldreieck vervollständigt. Zwei Jahre später folgte mit der Novellierung des Stromeinspeisungsgesetzes aus dem Jahr 1991 die erste Fassung des Erneuerbare-Energien-Gesetzes (EEG), welches zum Ziel hatte, ,im Interesse des Klima- und Umweltschutzes eine nachhaltige Entwicklung der Energieversorgung zu ermöglichen [...]“" (EEG 2000).

Damit wurden die wesentlichen Eckpfeiler des heutigen „Energiewenderechts“ vor knapp 20 Jahren gelegt. Seither ist das Energiewenderecht sowohl im Umfang als auch in der Komplexität erheblich gewachsen. Als einfache Indikatoren hierfür lassen sich die Anzahl der Paragraphen und die Anzahl der Wörter der jeweiligen Normen heranziehen (Waltl und Matthes 2014). Diese Entwicklung ist hier in indexierter Form dargestellt (Abb. 1). Nimmt man die Anzahl der Wörter als Maßstab, so hat sich der Umfang beider Gesetze mehr als verzwanzigfacht. Überschlägig entspricht das einer Verdopplung alle vier Jahre.

Während ein Großteil des EnWG Wachstums bis zum Jahr 2010 auf die Umsetzung der EU-Liberalisierungspakete zurückgeht, bot das EEG lange ein Innovationsumfeld mit hohen $\mathrm{Zu}$ wachsraten von Erneuerbaren Energien bei vergleichsweise geringer regulatorischer Anpassung (Böhringer et al. 2017; EWK 2014). Allerdings sind beide Vorschriften nach der Verabschiedung des sogenannten „Gesetzespaket zur Energiewende“ aus dem Jahr 2011 (Ortlieb 2011) einer besonderen Wachstumsdynamik unterworfen. Dabei ist nicht nur das Wachstum der Komplexität problematisch, sondern insbesondere auch die Regulierungsintensität und Änderungsfrequenz.
This is an article distributed under the terms of the Creative Commons Attribution License CCBY 4.0 (https://creativecommons.org/licenses/by/4.0/) https://doi.org/10.14512/tatup.28.3.48

Submitted: 28. 06. 2019. Peer reviewed. Accepted: 24.10.2019 
Angesichts der zunehmenden Diskontinuität und Dynamik des regulatorischen Rahmens herrscht unter den handelnden Akteuren große Unsicherheit. Regulatorische Risiken schweben wie ein Damoklesschwert über der Entwicklung von Geschäftsmodellen. Gesetzesänderungen können binnen kurzer Zeit - gewollt oder ungewollt - Geschäftsmodelle ermöglichen, aber genauso schnell wieder ,unwirtschaftlich regulieren“ oder streichen.

Exemplarisch ist hierfür das sogenannte „Grünstromprivileg“ zu nennen, welches eine gesetzliche Regelung im EEG 2009 zur vollständigen Zahlungsbefreiung von der EEG-Umlage für Energieversorgungsunternehmen darstellte, die - bezogen auf die gesamte von ihnen an Letztverbraucher abgegebene Strommenge mindestens $50 \%$ Strom aus erneuerbaren Energien an Letztverbraucher*innen lieferten. Über dieses Instrument zur Marktintegration wurden im Jahr 2011 mehr als $10 \%$ der gesamten EEG-Strommengen an Letztverbraucher*innen direktvermarktet (siehe Abb. 2).

Das Grünstromprivileg kreierte ein Innovationssystem aus (1) EEG-Anlagenbetreibern, (2) Marktintegratoren bzw. Energieversorgungsunternehmen und (3) Grünstromkonsument*innen. Aus Sorge um die steigernde Wirkung des Instruments auf die EEG-Umlage wurden die Regelungen im EEG 2012 verschärft und schließlich im EEG 2014 ersatzlos gestrichen. EEG-Anlagenbetreiber*innen konnten fortan ihren Strom nur noch über Direktvermarktungsunternehmen als Graustrom vermarkten, denn die ,grüne“ Eigenschaft des Stroms wurde allen Stromkunden zugeteilt. Energieversorgungsunternehmen konnten entsprechend nur noch auf Basis zumeist ausländischer Herkunftsnachweise Grünstromprodukte auflegen und vermarkten. In der Folge zerfiel die Wertschöpfungskette von EEG-Anlagenbetreiber*innen über Marktintegratoren hin zu Grünstromkonsument*innen in isolierte Fragmente. Marktakteure, die auf Basis des Grünstromprivilegs Geschäftsmodelle entwickelten, mussten diese in kürzester Zeit wieder aufgeben, umsteuern und ggf. getätigte Investitionen abschreiben.

Als ähnliche Bespielfälle lassen sich in unterschiedlicher Ausprägung die Einführung der (Teil-)EEG-Umlagepflicht auf

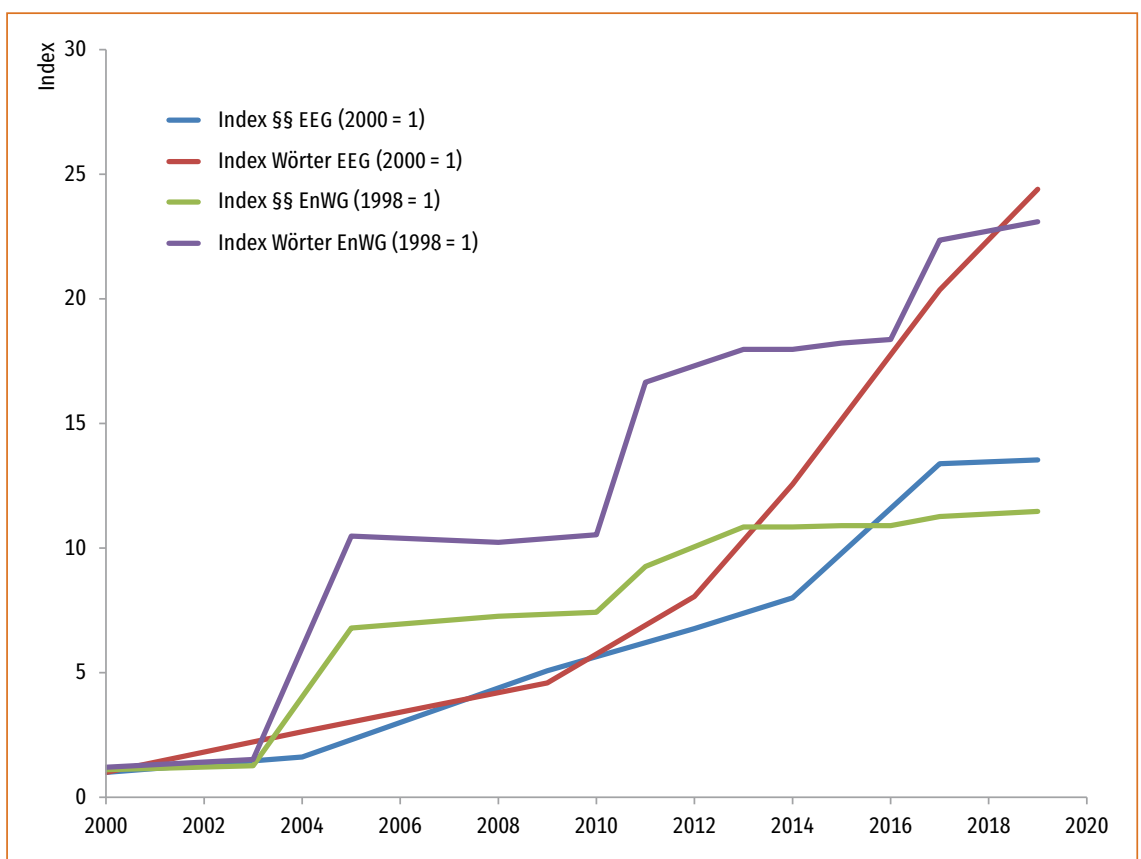

Abb.1: Entwicklung der Anzahl der Paragraphen und Wörter des EEG und des EnWG. Buchstaben-Paragraphen wurden als separate Paragraphen gezählt.

Quelle: GII 2019, Wayback Machine 2019, eigene Berechnungen

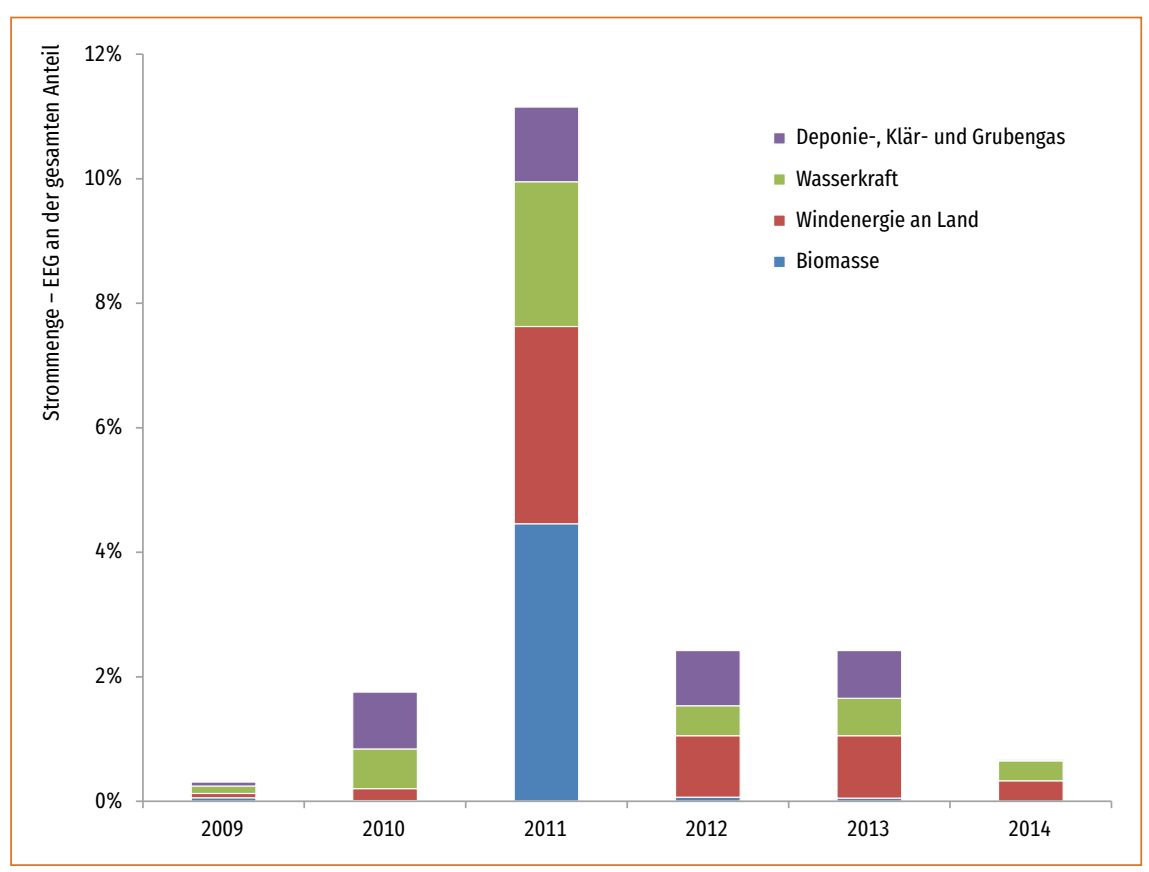

Abb. 2: Anteil der durch das Grünstromprivileg vermarkteten EEG-Strommengen.

Quelle: BMWI 2018a eigenerzeugten Eigenverbrauch im EEG 2014 oder die Änderungen zu den Regularien im Bereich des Mieterstroms nennen. Im vorliegenden Kontext geht es dabei jedoch weniger um die Frage, ob die Regularien die Richtigen waren beziehungsweise sind, sondern um die Tatsache, dass durch den Gesetzgeber in- 
stehende Rahmenbedingungen und Hemmnisse geöffnet bzw. abgebaut und Wissensdefizite reduziert werden.

Ein Beispiel hierfür ist die auf $\S 119$ Abs. 1 EnWG beruhende Verordnung zur Schaffung eines rechtlichen Rahmens zur Sammlung von Erfahrungen im Förderprogramm „Schaufenster intelligente Energie - Digitale Agenda für die Energiewende“ (SINTEG-V). Die Verordnung ist das regulatorische Grundgerüst des Förderprogramms. Sie sieht Abweichungen von bestehenden Vorschriften vor. So sollen zum Beispiel wirtschaftliche Nachteile, die aufgrund des Experiments auftreten, erstattet werden. Die am 30. Juni 2022 auslaufende Förderregel dient ausdrücklich zur Erfahrungssammlung. Die gewonnenen Erfah-

\section{Sonderwirtschaftszone}

Ein weiteres Instrument um (großflächige) Transformationsprozesse rechtlich zu gestalten sind Sonderwirtschaftszonen (SWZ). Das für die Bundesrepublik noch kaum genutzte Instrument wird auch im Rahmen des Abschlussberichts der Kommission WSB als Förderinstrument genannt (Kommission WSB 2019).

Die SWZ lässt sich rechtlich zunächst als räumlich oder sachlich begrenzter Bereich bezeichnen, in dem für bestimmte Wirtschaftsbereiche bzw. Regelungsbereiche andere Regeln gelten als in den übrigen Bereichen derselben Gerichtsbarkeit (Röhl 2004, S. 6 f.). Ausgehend vom Begriff der Wirtschaftszone und dem (vornehmlichen) Verwendungszweck dienen die SWZ der

\section{Zum Erreichen des 1,5-Grad-Ziels und damit für ein Gelingen der Energiewende bedarf es innovativer Technologien und Geschäftsmodelle.}

rungen sollen evaluiert und in einem Bericht dem Bundestag vorgelegt werden.

Obgleich Experimentierklauseln durchaus geeignet sein können Innovationen anzureizen, erweisen sie sich keineswegs als Allheilmittel. Neben der Frage der konkreten Ausgestaltung (,design matters“, Rodi 2009) bestehen für Experimentierklauseln grundsätzliche Risiken bzw. Schwächen. Als Regel-Ausnahme-Normierung stehen sie unter den Grenzen einer (strengen) Verhältnismäßigkeitsprüfung und erfordern eine hinreichende Bestimmtheit. Die Reichweite der Anwendung ist eingeschränkt und muss vom Gesetzgeber von Anfang an geregelt werden (Maßß 2001). So hat sich der Gesetzgeber auch im Rahmen der SINTEG-V für einen äußerst engen Anwendungsbereich entschieden, der systemdurchbrechende Änderungen kaum zulässt (Groebel 2019). Zudem handelt es sich bei Experimentierklauseln um Zeitgesetze, also eine befristete Regulierung. Rechtssicherheit, dass neue Technologien und Geschäftsmodelle sich nachhaltig etablieren, besteht für die Akteure damit nicht. Ein Überdauern der in der Spielwiese erprobten Neuerungen ist ungewiss.

Auch die SINTEG-V enthält ausdrücklich kein Präjudiz über zukünftige Regulierungen. Unsicherheiten und Risiken wälzt der Gesetzgeber damit auf die übrigen Akteure ab. Es lässt sich bezweifeln, ob ein Diskriminierungseingriff, der zugunsten einzelner Marktteilnehmer*innen befristete Sonderregelungen schafft, zur Entwicklung von Geschäftsmodellen und Technologie-Innnovationen führen kann (EWK 2018). Aus Sicht rational handelnder Wirtschaftssubjekte ist die Wirkung vergleichbar mit einer temporären Förderung, die nur schwerlich strategische Ressourcen zur Geschäftsmodellentwicklung oder Technologieentwicklung mobilisieren kann. Ohne weitergehende Perspektive werden wohl überwiegend lediglich Mitnahmeeffekte generiert. räumlichen Wirtschaftsförderung (Röhl 2004). Mittel dieser Förderung ist zumeist eine (größtmögliche) Deregulierung oder sonstige Form der Befreiung von Investitions- und Produktionshemmnissen (Zoll 1990).

SWZ können auch herangezogen werden, um abseits von bloßen Deregulierungen legislative und technologische Transformationsprozesse voranzutreiben bzw. zu erproben (Martinek 2018). Neben der besonderen Zugkraft für Investitionen kann die SWZ damit auch Raum für neue Entwicklungen, Technologien und Geschäftsmodelle schaffen (Yiming 2017). In Abgrenzung zu den Experimentierklauseln lassen sich SWZ räumlich als eine weitergefasste, regionale Innovationsförderung verstehen (Ginsburg 2016). Auch die Kohlekommission ordnet Sonderförderregionen den Reallaboren und Experimentierklauseln zu (Kommission WSB 2019, S. 96 f.). Sie sollen Grundlage für Modell- und Innovationsregionen sein (Kommission WSB 2019, S.97).

Wie Experimentierklauseln steht die SWZ vor der Herausforderung, zu fördernde aber bisher unbekannte Innovationen regulatorisch aufzunehmen. Im Verhältnis zur Experimentierklausel erweist sich die SWZ als nicht unwesentlich komplexer. Bereits als Förderinstrument in Form der Deregulierung erfordert die SWZ einen umfassenden Rechtsrahmen für die gesondert regulierte Region (,dual legal order“, Martinek 2018). Dabei genügt die Deregulierung keineswegs. Treten Experimentierklauseln zur Deregulierung hinzu, entsteht ein hochkomplexes (räumlich eigenständiges) Rechtsgebiet. Ob dieses im Wechselspiel mit den übrigen Regionen tatsächlich noch eine besondere Zugkraft und Innovationsförderung gewährleistet, kann zumindest bezweifelt werden. Findet die Implementierung der Innovationen ausschließlich innerhalb der SWZ statt, scheitert also die weitergehende Übertragung und Skalierung, drohen zudem systemrelevante Wirkungen auszubleiben. 


\section{$\mathrm{CO}_{2}$-Bepreisung}

Im politischen Diskurs hochaktuell und auch Gegenstand wissenschaftlicher Untersuchungen ist die $\mathrm{CO}_{2}$-Bepreisung (EWK 2016; Agora 2018; SVR 2019). Diese soll Lenkungswirkung entfalten und Innovationspotenziale heben.

$\mathrm{CO}_{2}$-Bepreisung meint ein einheitliches, staatliches Finanzierungsinstrument mit Lenkungswirkung, bei welchem der Verbrauch bzw. der Ausstoß einer gewissen $\mathrm{CO}_{2}$-Menge mit einem abzuführenden Betrag versehen wird. $\mathrm{CO}_{2}$ bekommt demnach einen Preis. Regelmäßig ist ein stetiger Anstieg des Preises vorgesehen. Durch die $\mathrm{CO}_{2}$-Bepreisung sollen treibhausgasintensive Prozesse und Produkte belastet und entsprechend treibhausgasarme Prozesse und Produkte entlastet werden.

Damit adressiert die $\mathrm{CO}_{2}$-Bepreisung nicht ausdrücklich Technologien und Geschäftsmodelle, sondern deren dekarbonisierende Wirkung. Sie ist ein technologieneutrales Instrument, welches bei einer entsprechenden Anwendung Komplexitäten abbauen kann (Agora Energiewende 2018). Mit Blick auf die regelmäßig absehbar steigende Bepreisung kann sie auch Anreize für Investitionen in innovative, treibhausgasreduzierende Technologien und Geschäftsmodelle setzen (Lenkungswirkung).

In der Schweiz besteht seit 2008 eine $\mathrm{CO}_{2}$-Abgabe auf fossile Brennstoffe. Die sogenannte Lenkungsabgabe fällt auf fossile Brennstoffe an, die in bestimmten Prozessen, bspw. der Wärme- bzw. Stromerzeugung, eingesetzt werden. Demgegenüber sind erneuerbare Brennstoffe - wie Biomasse - privilegiert. Für diese fällt die Abgabe nicht an. Der schweizerische Gesetzgeber hat für die Abgabe einen Höchstsatz von 120 Franken festgeschrieben. Die genaue Höhe der Abgabe wird dynamisch bestimmt. Sie stieg in den Jahren 2008 bis 2018 von anfangs 12 Franken, über 64 Franken, auf nunmehr 96 Franken pro Tonne $\mathrm{CO}_{2}$. Das Bundesamt für Umwelt (BAFU) attestiert der Abgabe in den einschlägigen Sektoren höhere Wirkung als anderen Instrumenten (BAFU 2018).

Abseits der Kritik an der $\mathrm{CO}_{2}$-Bepreisung wegen sozialer Härten und deren Ausgleich, kann auch die Eignung als Instrument zur energierechtlichen Zukunftsgestaltung hinterfragt werden. So kann zunächst festgehalten werden, dass nicht alle relevanten Innovationsbereiche preissensitiv sind. Ein einheitlicher Preis schafft womöglich einen fairen Wettbewerb. Werden die bestehenden Rahmenbedingungen aber im Übrigen nicht verändert, können Innovationen weiterhin an Verboten und anderen ordnungsrechtlichen Hemmnissen scheitern. Für die Wirksamkeit der $\mathrm{CO}_{2}$-Bepreisung ist die Höhe der Abgabe entscheidend. Dies zeigt auch die zum Teil drastische Erhöhung der schweizerischen $\mathrm{CO}_{2}$-Abgabe, die sonst weitestgehend wirkungslos geblieben wäre. Auch die $\mathrm{CO}_{2}$-Bepreisung ist ein letztlich zeitlich beschränktes Instrument. Mit stetigem Nähern des Ziels einer klimaneutralen Gesellschaft, sinkt auch die Lenkungswirkung der $\mathrm{CO}_{2}$-Bepreisung. Darüber hinaus adressiert eine $\mathrm{CO}_{2}-\mathrm{Be}-$ preisung lediglich einen - wenn auch wesentlichen - Treiber des Klimawandels. Das Energiewenderecht ist jedoch kein bloBes Emissionseinsparungsrecht. Vielmehr zielt es insgesamt auf einen erhöhten Umweltschutz, sodass auch andere Bereiche der
Energiewende und Innovationen berücksichtigt werden müssen. $\mathrm{Zu}$ diesen gehören bspw. Fragen der Biodiversität und des Flächenverbrauchs.

\section{Fazit}

Mit Blick auf den Transformationsprozess der Energiewende und die hierfür notwendigen Innovationen bleiben erhebliche Herausforderungen, technologisch, ökonomisch, gesellschaftlich und auch rechtlich. Zur Bewältigung dieser Herausforderungen steht dem Gesetzgeber eine große Instrumentenauswahl zur Verfügung. Die Untersuchung hat gezeigt, dass die derzeit debattierten Instrumente für sich allein kein Garant für Innovation und Erfolg der Energiewende sind. Ausgehend von einer langfristigen, robusten Strategie zum Senken der Treibhausgasemissionen - etwa durch eine stetig ansteigende $\mathrm{CO}_{2}$-Bepreisung - kann der Gesetzgeber die energierechtliche Zukunftsgestaltung erfolgversprechend angehen. Diese Strategie kann und muss durch einzelne Experimentierklauseln oder SWZ unterstützt und mitgetragen werden. Dem folgend steht dem Gesetzgeber ein geeignetes Handwerkszeug zur Verfügung, mit dem er den Weg des Transformations- und Innovationsprozesses erfolgreich gestalten kann.

\section{Literatur}

AGEE-Stat - Arbeitsgruppe Erneuerbare Energien-Statistik (2019): Zeitreihen zur Entwicklung der erneuerbaren Energien in Deutschland (Stand: Februar 2019) Online verfügbar unter https://www.erneuerbare-energien.de/EE/Redaktion/ DE/Downloads/zeitreihen-zur-entwicklung-der-erneuerbaren-energien-indeutschland-1990-2018-excel.xlsx, zuletzt geprüft am 11.04.2019.

Agora Energiewende (2018): Eine Neuordnung der Abgaben und Umlagen auf Strom, Wärme, Verkehr. Optionen für eine aufkommensneutrale $\mathrm{CO}_{2}$-Bepreisung von Energieerzeugung und Energieverbrauch. Online verfügbar unter https://www.agora-energiewende.de/fileadmin2/Projekte/2017/Abgaben_ Umlagen/147_Reformvorschlag_Umlagen-Steuern_WEB.pdf, zuletzt geprüft am 18.06.2019.

BAFU - Bundesamt für Umwelt (2018): Faktenblatt Wirkungsabschätzung und Evaluation der C02-Abgabe auf Brennstoffe. Online verfügbar unter https:// www.bafu.admin.ch/dam/bafu/de/dokumente/klima/fachinfo-daten/ faktenblatt_1_c02-abgabe_auf_brennstoffe.pdf.download.pdf/faktenblatt_1_ c02-abgabe_auf_brennstoffe.pdf, zuletzt geprüft am 17.10.2019.

BMU - Bundesministerium für Umwelt, Naturschutz und nukleare Sicherheit (2019): Klimaschutzplan 2050. Klimaschutzpolitische Grundsätze und Ziele der Bundesregierung. Online verfügbar unter https://www.bmu.de/ fileadmin/Daten_BMU/Download_PDF/Klimaschutz/klimaschutzplan_2050_ bf.pdf, zuletzt geprüft am 27.06.2019.

BMWi - Bundesministerium für Wirtschaft und Energie (2018a): EEG in Zahlen. Vergütungen, Differenzkosten und EEG-Umlage 2000 bis 2019 (Stand: 15. Oktober 2018). Online verfügbar unter https://www.erneuerbareenergien.de/EE/Redaktion/DE/Downloads/eeg-in-zahlen-pdf.pdf\%3F blob\%3DpublicationFile, zuletzt geprüft am 17.10.2019.

BMWi (2018b): Reallabore. Testräume für Innovation und Regulierung. Online verfügbar unter https://www.bmwi.de/Redaktion/DE/Dossier/reallabore- 
testraeume-fuer-innovation-und-regulierung.html, zuletzt geprüft am 18.06.2019.

BNetzA - Bundesnetzagentur (2019): Kraftwerksliste Bundesnetzagentur. Stand: 07. März 2019. Bundesnetzagentur für Elektrizität, Gas, Telekommunikation, Post und Eisenbahnen. Bonn. Online verfügbar unter https://www.bundesnetzagentur.de/DE/Sachgebiete/ElektrizitaetundGas/ Unternehmen_Institutionen/Versorgungssicherheit/Erzeugungskapazitaeten/ Kraftwerksliste/kraftwerksliste-node.html, zuletzt geprüft am 19.05.2019.

Böhringer, Christoph; Cuntz, Alexander; Harhoff, Dietmar; Asane-Otoo, Emmanuel (2017): The impact of the German feed-in tariff scheme on innovation. Evidence based on patent filings in renewable energy technologies. In: Energy Economics 67 (C), S. 545-553.

Diehl, Andrea (2014): Innovationsfördernde dynamische Regulierung. BadenBaden: Nomos.

Ekardt, Felix; Wieding, Jutta; Zorn, Anika (2018): Paris agreement, precautionary principle and human rights. Zero emissions in two decades? Online verfügbar unter https://www.mdpi.com/2071-1050/10/8/2812, zuletzt geprüft am 12.09.2019.

EWK - Expertenkommission zum Monitoring-Prozess „Energie der Zukunft“ (2012): Stellungnahme zum ersten Monitoring-Bericht der Bundesregierung für das Berichtsjahr 2011. Berlin: o. V.

EWK (2014): Stellungnahme zum ersten Fortschrittsbericht der Bundesregierung für das Berichtsjahr 2013. Berlin: 0. V.

EWK (2016): Stellungnahme zum fünften Monitoring-Bericht der Bundesregierung für das Berichtsjahr 2015. Berlin: 0.V.

EWK (2018): Stellungnahme zum fünften Monitoring-Bericht der Bundesregierung für das Berichtsjahr 2017. Berlin: o. V.

Franzius, Claudio (2015): Regulierung und Innovation im Mehrebenensystem. In: Die Verwaltung 48, S. 175-201.

Gawel, Erik (2009): Technologieförderung durch „Stand der Technik“. In: Martin Eifert und Wolfgang Hoffmann-Riem (Hg.): Innovationsfördernde Regulierung. Berlin: Duncker \& Humblot, S. 197-220.

GII (2019): „Gesetze im Internet“. Online verfügbar unter www.gesetze-iminternet.de, zuletzt geprüft am 18. 04.2019.

Ginsburg, Tom (2016): Special economic zones. A constitutional political economy perspective. In: Jürgen Basedow und Toshiyuki Kono (Hg.): Special economic zones. Law and policy perspectives. Tübingen: Mohr Siebeck, S. 130-141.

Groebel, Annegret (2019): §119a EnWG. In: Jürgen Säcker (Hg.): Berliner Kommentar zum Energierecht. Frankfurt am Main: dfv Mediengruppe, S. 4037-4046.

Kommission WSB - Kommission „Wachstum, Strukturwandel und Beschäftigung“ (2019): Abschlussbericht. Online verfügbar unter https://www.bmwi.de/ Redaktion/DE/Downloads/A/abschlussbericht-kommission-wachstumstrukturwandel-und-beschaeftigung.pdf?__blob=publicationFile\&v=4, zuletzt geprüft am 18. 06.2019.

Korff, Rüdiger (2016): Resilienz. Eine Frage von Biegen oder Brechen im Ausnahmefall. In: Kai von Lewinski (Hg.): Resilienz des Rechts. Baden-Baden: Nomos, S. 23-32.

Martinek, Madeleine (2018): Experimental legislation in China between efficiency and legality. Cham: Springer.

Maaß, Volker (2001): Experimentierklauseln für die Verwaltung und ihre verfassungsrechtlichen Grenzen. Berlin: Duncker \& Humblot.

Ortlieb, Birgit (2011): Das Gesetzespaket zur Energiewende. Zusammenfassender Überblick über die wesentlichen Inhalte der acht am 8. Juli 2011 endgültig verabschiedeten, mittlerweile im Bundesgesetzblatt veröffentlichten (und zum größten Teil auch bereits in Kraft getretenen) Gesetze. In: EWeRK 11 (4), S. 151-156.

Rodi, Michael (2009): Innovationsförderung durch ökonomische Instrumente der Umweltpolitik. In: Martin Eifert und Wolfgang Hoffmann-Riem (Hg.): Innovationsfördernde Regulierung. Berlin: Duncker \& Humblot, S. 146-169.

Röhl, Klaus-Heiner (2004): Sonderwirtschaftszonen als Instrument der Regionalentwicklung. Neue Ideen für die neuen Bundesländer. Köln: Deutscher Instituts-Verlag.

Roßnagel, Alexander (2007): Innovation als Gegenstand der Rechtswissenschaft. In: Hagen Hof und Ulrich Wengenroth (Hg.): Innovationsforschung - Ansätze, Methoden, Grenzen und Perspektiven. Münster: Lit, S. 9-22.

SVR - Sachverständigenrat zur Begutachtung der gesamtwirtschaftlichen Lage (2019): Aufbruch zu einer neuen Klimapolitik. Sondergutachten. Online verfügbar unter https://www.sachverstaendigenrat-wirtschaft.de/fileadmin/ dateiablage/gutachten/sg2019/sg_2019.pdf, zuletzt geprüft am 25. 09.2019.

Waltl, Bernhard; Matthes, Florian (2014): Towards measures of complexity. Applying structural and linguistic metrics to German laws. $27^{\text {th }}$ International Conference on Legal Knowledge and Information Sytems. Krakau, Polen, 10. 12.2014.

Wayback Machine (2019): Internet archive. Online verfügbar unter http://web. archive.org/, zuletzt geprüft am 25.04.2019.

Yiming, Yuan (2017): The dynamic evolution of China's special economic zones and their practice. In: Yuan Yiming (Hg.): Studies on China's special economic zones. Singapur: Springer, S. 13-22.

Zoll, Jürgen (1990): Freizonen im internationalen Wirtschaftsrecht. Völkerrechtliche Schranken exzessiver Wirtschaftsförderung. Baden-Baden: Nomos.

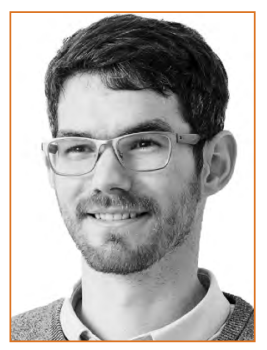

MICHAEL KALIS

forscht seit 2018 am IKEM zu den rechtlichen Rahmenbedingungen von Experimentierklauseln, Reallaboren und grünen Gasen.

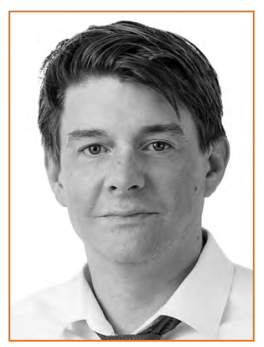

\section{LARS DITTMAR}

erforscht seit 2019 am IKEM wirtschaftswissenschaftliche und technische Fragenstellungen der Energiewende. Zuvor unterstütze er seit der Gründung im Jahr 2011 die Expertenkommission des Energiewende-Monitorings in Deutschland und analysierte in diesem Zusammenhang die Fortschritte der Energiewende. 


\title{
Energieeffizienz im Spannungs- feld zwischen Anlagentechnik und sozialen Akteuren
}

Hemmnisse für den effizienten Betrieb komplexer Heizungsanlagen

\author{
Uta Böhm, Zentrum Technik und Gesellschaft, Technische Universität Berlin, Hardenbergstr.16-18, 10623 Berlin (boehm@ztg.tu-berlin.de) \\ Martina Schäfer, Zentrum Technik und Gesellschaft, Technische Universität Berlin (schaefer@ztg.tu-berlin.de) \\ Maria Stadler, Zentrum Technik und Gesellschaft, Technische Universität Berlin (stadler@ztg.tu-berlin.de)
}

Ein energieeffizienter Betrieb von Heizungsanlagen wird als Beitrag zum Erreichen der Klimaschutzziele immer bedeutsamer. Da zukunftsweisende Entwicklungen primär technischen Innovationen zugeschrieben werden, wurden in den vergangenen Jahren in vielen Gebäuden moderne Anlagen installiert. In der Praxis zeigt sich jedoch, dass die prognostizierten Einsparungen meist nicht erreicht werden. Anhand der empirischen Ergebnisse des Forschungsprojektes ENGITO wird deutlich, dass dies vielfach auf soziale Hemmnisse zurückzuführen ist, die bislang zu wenig berücksichtigt werden. Im Folgenden wird auf typische Hemmnisse für den effizienten Anlagenbetrieb eingegangen, wobei deutlich wird, dass bei der Gestaltung zukünftiger Energiesysteme arbeitsorganisatorische Aspekte eine grundlegende Rolle spielen. Energieeffizienz wird dabei aus soziotechnischer Perspektive betrachtet und als Ergebnis des Zusammenspiels technischer Voraussetzungen und sozialer Akteure verstanden.

\section{Energy efficiency as interplay between technical installations and social actors \\ Barriers to the efficient operation of complex heating systems}

In order to achieve climate protection targets, energy-efficient operation of heating systems is of central importance to achieving climate protection targets. So far, innovation of the energy system has primarily been attributed to technological innovation. Therefore, modern energy systems have been installed in many buildings over the last two decades. However, in practice, predicted savings are usually not achieved. The empirical results of the ENGITO project show that this is often due to social barriers, which have hardly been considered so far. The article addresses typical barriers to efficient operation of heating systems and shows that work organization and distribution of responsibility play an important role in shaping future energy systems. In this arti-

This is an article distributed under the terms of the Creative Commons Attribution License CCBY 4.0 (https://creativecommons.org/licenses/by/4.0/)

https://doi.org/10.14512/tatup.28.3.55

Submitted: 20.05.2019. Peer reviewed. Accepted: 02.10.2019 cle, energy efficiency is viewed from a socio-technical perspective and understood as interplay between technological installations and social actors.

Keywords: energy efficiency, socio-technical system, heating techno$\log y$

\section{Einleitung}

Für die Wärmeversorgung als Teil des zu transformierenden Energiesystems wird in Deutschland gegenwärtig ca. ein Drittel der gesamten Primärenergie aufgewendet (BMWi 2018a, S. 57). Daher spielt der energieeffiziente Betrieb von Heizungsanlagen für das Erreichen der Klimaschutzziele der Bundesregierung eine bedeutende Rolle. Bis 2050 soll demnach der Gebäudebestand nahezu klimaneutral sein (BMU 2016). Im Zuge dieser Bestrebungen wurden in den vergangenen Jahren vielfältige Forschungsaktivitäten unternommen. Durch Bundesministerien geförderte Projekte haben dabei schwerpunktmäßig Möglichkeiten für Energieeinsparungen auf regionaler Ebene (DACH Energieeffiziente Stadt 2019), Best-Practice-Beispiele für Sanierungsprojekte (LowEx Bestand 2018) oder die Verbesserung der Datenlage zum energetischen Gebäudezustand (ENOB: dataNWG 2019) verfolgt. Außerdem legt das derzeitige Energieforschungsprogramm der Bundesregierung seinen Schwerpunkt auf die Entwicklung innovativer Technologien und deren Transfer in die Praxis (BMWi 2018b).

Auffällig ist, dass in den bisherigen Forschungsprojekten technische Aspekte häufig im Vordergrund stehen. Sofern Akteure oder organisationale Strukturen einbezogen werden, handelt es sich meist um Studien zur Investitionsbereitschaft, zu Hindernissen für Sanierungsvorhaben und zur Optimierung von Beratungsleistungen (dena 2017; c.HANGE 2019). Mit- 
unter werden auch Nutzerverhalten und Akzeptanz berücksichtigt (BBSR 2019; UfU 2017). Die konkreten Interaktionsbeziehungen zwischen unterschiedlichen Akteuren und der Anlagentechnik während des Betriebs werden jedoch kaum betrachtet.

Anliegen des interdisziplinären Forschungsprojektes ENGITO $^{1}$ (2019), auf dessen Befunden der Artikel basiert, ist es, die Komplexität des Umbaus von Energiesystemen als Zusammenspiel von technischen und sozialen Aspekten in den Blick $\mathrm{zu}$ nehmen. Dabei werden Akteure verschiedener Entscheidungs- und Zuständigkeitsebenen einbezogen. Im Fokus steht der Betrieb von Wärmetechnik in öffentlichen Nichtwohngebäuden u. a. in kommunalen Unternehmen, Schulen und Kitas. Der Beitrag zielt darauf ab, Möglichkeiten für die Gestaltung soziotechnischer Systeme aufzuzeigen. Auf Basis einer breit angelegten Studie, insbesondere in öffentlichen Einrichtungen, werden für konkrete Anlagen und Arbeitskontexte Einsparpotenziale im gering investiven Bereich identifiziert. Damit ist vor allem die Transformation der bestehenden Betriebspraxis in der nahen $\mathrm{Zu}$ kunft Gegenstand der Betrachtung.

\section{Energieeffiziente Wärmeerzeugung aus soziotechnischer Perspektive}

Ein energieeffizienter Anlagenbetrieb, so die These des vorliegenden Beitrags, kann langfristig nur gewährleistet werden, wenn soziale und technische Aspekte in ihrer Wechselwirkung betrachtet und optimiert werden. Den theoretischen Ausgangspunkt bildet somit ein soziotechnisches Verständnis von Interaktionszusammenhängen. Demzufolge besteht das Arbeitssystem der Wärmeerzeugung aus einem technischen und einem sozialen Teilsystem, die sich gegenseitig beeinflussen und bedingen
Aufrechterhalten in Form von Praktiken des Betreibens, Instandhaltens und Reparierens (Star 1999).

Energieeffizienz wurde aus soziotechnischer Perspektive bisher entweder über deren organisationale Voraussetzungen oder über die Praktiken der Techniknutzung verstanden. Axon et al. (2012) und Janda (2014) beschreiben Energieeffizienz im Kontext sogenannter building communities. Dabei werden Gebäude und ihre Nutzer*innen als communities of practice betrachtet, deren Effizienz durch Rahmenbedingungen wie gesetzliche Vorgaben, durch Voraussetzungen der Eigentümer*innen (wie verfügbare finanzielle Ressourcen) sowie durch individuelle Nutzungspraktiken beeinflusst wird. Im Fokus der interdisziplinären Betrachtung stehen die Zusammenhänge zwischen Faktoren der Makro-, Mikro- und Mesoebene. Auch Shove (2017) und Pettersen et al. (2017) betrachten Energieeffizienz aus praxissoziologischer Perspektive. Shove beschreibt Praktiken des Energieverbrauchens, die in technische Infrastrukturen eingebettet sind. Sie problematisiert, dass durch effizientere Technik der Energiebedarf und die Standards eher steigen und nicht mehr hinterfragt werden, was zu Rebound-Effekten führt (Shove 2017). Pettersen at al. (2017) beschreiben den unterschiedlichen Umgang mit technischen Standards in der Praxis. Ihr Ausgangspunkt ist die Beobachtung einer Diskrepanz zwischen prognostizierten und realisierten Einsparungen, auf der auch der vorliegende Beitrag aufbaut. Die technische Infrastruktur wird hier allerdings nicht nur als Basis für energieeffiziente Praktiken verstanden, sondern es wird das aktive Zusammenspiel technischer und sozialer Komponenten betrachtet. Der vorliegende Artikel konzeptualisiert Energieeffizienz somit als verteilte Handlung (Rammert 2016). Damit soll betont werden, dass Energieeffizienz weder als alleinige Aufgabe moderner Anlagentechnik, noch ausschließlich als soziale Praktik verstanden werden kann.

\section{Für einen energieeffizienten Anlagenbetrieb müssen technische und soziale Komponenten zusammenspielen.}

(Ropohl 2009). Wechselwirkungen zwischen sozialen und technischen Aspekten können einerseits in der Phase der Technikgenese und -planung, andererseits in der Phase der Techniknutzung betrachtet werden. Im Zuge der Anlagenplanung wird die Vorstellung einer zukünftigen Nutzungsweise in das Anlagensetting eingeschrieben (Akrich 1997). Damit sind Interaktionszusammenhänge zwischen technischen und sozialen Teilsystemen für die spätere Phase der Techniknutzung bereits vorstrukturiert. Dennoch funktioniert installierte Anlagentechnik nicht ohne Zutun der sozialen Akteure, sondern erfordert beständiges

1 Das Projekt ENGITO (Energieeinsparung durch gering-investive technische und organisatorische Maßnahmen an komplexen Wärme- und Kälteanlagen) wird an der TU Berlin vom Fachgebiet Maschinen- und Energieanlagentechnik und dem Zentrum Technik und Gesellschaft von 2017-2020 durchgeführt. Förderung: Berliner Programm für Nachhaltige Entwicklung (BENE).
Vielmehr ist es notwendig, den energieeffizienten Anlagenbetrieb als Ergebnis des Zusammenspiels technischer und sozialer Komponenten zu betrachten.

Rammert plädiert dafür, statt einer dualistischen Perspektive auf die Frage, wer in soziotechnischen Konstellationen die Handlungsträgerschaft übernimmt, das wechselseitige Zusammenwirken zu betrachten. Handlungen beinhalten dabei immer sowohl technische als auch soziale Komponenten. Sie sind ,in ihrem Vollzug auf verschiedenartige, eben menschliche und nicht-menschliche Instanzen verteilt" (Rammert 2016, S. 151). Unterscheiden lässt sich lediglich die Form des Zusammenspiels und die Zuschreibung von Verantwortung. Diese Perspektive aufgreifend, soll untersucht werden, wie die Zuständigkeiten für den energieeffizienten Anlagenbetrieb zwischen den Teilsystemen verteilt sind. 


\begin{tabular}{|c|c|c|c|}
\hline Erhebung & Akteure & Anzahl & gesamt \\
\hline \multirow[t]{3}{*}{ Interviews in Liegenschaften } & Gebäude- und Energiemanager*innen & 17 & \multirow[b]{3}{*}{44} \\
\hline & Anlagenbetreuer*innen (z. B. Hausmeister*innen) & 16 & \\
\hline & Gebäudenutzer*innen & 11 & \\
\hline \multirow[t]{4}{*}{ Expert*innen-interviews } & Anlagenplaner*innen & 4 & \multirow[b]{4}{*}{12} \\
\hline & Energieeffizienzberater*innen & 2 & \\
\hline & Expert*innen Energiespar-Contracting & 3 & \\
\hline & Expert*innen Anreizsetzung & 3 & \\
\hline \multirow[t]{3}{*}{ Workshops } & Gebäude- und Energiemanager*innen & 1 & \multirow[b]{3}{*}{3} \\
\hline & Geschäftsführer*innen Wartungs- und Instandsetzungsfirmen & 1 & \\
\hline & Energiemanager*innen, - beauftragte, -berater*innen & 1 & \\
\hline
\end{tabular}

Tab.1: Sozialwissenschaftliche Erhebungen des Forschungsprojektes ENGITO (2019).

Quelle: Eigene Darstellung

Im betrachteten Kontext umfasst das technische Teilsystem die komplexen Wärmeanlagen, die Gebäudeleittechnik, Arbeitsmittel sowie definierte Anforderungen und Gesetze. Das soziale Teilsystem beinhaltet die Organisationsmitglieder, die auf unterschiedlichen Ebenen für die Anlagen zuständig sind (Planung, Management, Betrieb, Reparatur, Wartung) sowie die Gebäudenutzer*innen. Weiterhin zählen dazu die informellen Beziehungen der Organisationsmitglieder, ihre fachlichen Kompetenzen, Interessen und Bedürfnisse sowie der tatsächliche Umgang mit den Formalitäten, der durchaus von den Regelungen abweichen kann. Es wird davon ausgegangen, dass ein energieeffizienter Anlagenbetrieb nur erreicht wird, wenn beide Teilsysteme die ihnen zugeschriebenen Anteile an der gemeinsamen Handlung erfüllen. Hemmende Faktoren, z. B. eine hohe Arbeitsbelastung der Beschäftigten oder technische Mängel an den Anlagen, können die jeweiligen Teilsysteme an der Ausführung ihrer Aufgaben hindern. Dies kann dazu führen, dass das Zusammenspiel der Systeme blockiert und die angestrebte Effizienz nicht erreicht wird. Aus der Perspektive des hier dargelegten Ansatzes sollen im Folgenden Hemmnisse für den energieeffizienten Betrieb von Wärmeanlagen betrachtet werden, die bei der Anlagenplanung, der Inbetriebnahme und im Betrieb auftreten.

\section{Methodisches Vorgehen und Datenbasis}

Um Energiesparpotenziale an Anlagen öffentlicher Liegenschaften $\mathrm{zu}$ ermitteln, werden im Rahmen des Forschungsprojektes ENGITO (2019) technische Kurzzeitmesskampagnen und sozialwissenschaftliche Erhebungen durchgeführt und deren Ergebnisse verschränkt (Böhm und Buchin 2019). Die technischen Analysen erfolgen auf Grundlage nicht-invasiver Messungen von Temperaturen und Volumenströmen sowie der Auswertung von Verbrauchsdaten. Die sozialwissenschaftlichen Erhebungen um- fassen qualitative Interviews mit relevanten Liegenschaftsvertreter*innen, Expertengespräche und Workshops mit Praxisvertreter*innen (siehe Tab. 1).

Die vorliegenden Ergebnisse basieren auf Erhebungen und Messungen, die im Zeitraum von Juni 2017 bis März 2019 durchgeführt wurden. Die Befunde stützen sich auf insgesamt 56 qualitative, leitfadengestützte Interviews mit Akteuren verschiedener Ebenen von der Anlagenplanung bis zur Betreuung während des Betriebs. Befragt wurden Beschäftigte von 15 Berliner Liegenschaften, in denen jeweils drei bis vier Interviews mit unterschiedlichen Personengruppen geführt wurden. Inhaltliche Schwerpunkte der ca. einstündigen Gespräche waren

\section{Die Ergebnisse zeigen: Ineffizienter Anlagenbetrieb ist meist auf arbeitsorganisatorische Aspekte zurückzuführen.}

arbeitsorganisatorische Aspekte, Anforderungen und Rahmenbedingungen für den Anlagenbetrieb, Kommunikationsstrukturen im Arbeitsalltag, Schwierigkeiten bezüglich des energieeffizienten Anlagenbetriebs sowie der Stellenwert von Energieeinsparungen im Arbeitsbereich.

Zusätzlich wurden ausgewählte Expert*innen verschiedener Bereiche zu hemmenden Faktoren für den effizienten Anlagenbetrieb und zu Maßnahmen für deren Bewältigung befragt. Die Interviews wurden aufgezeichnet (Audioaufnahme), vollständig transkribiert, mittels der Analysesoftware MAXQDA codiert und inhaltsanalytisch ausgewertet. Weiterhin wurden drei Workshops mit Praxisvertreter*innen aus den Bereichen Gebäude- und Energiemanagement, Energieberatung sowie War- 


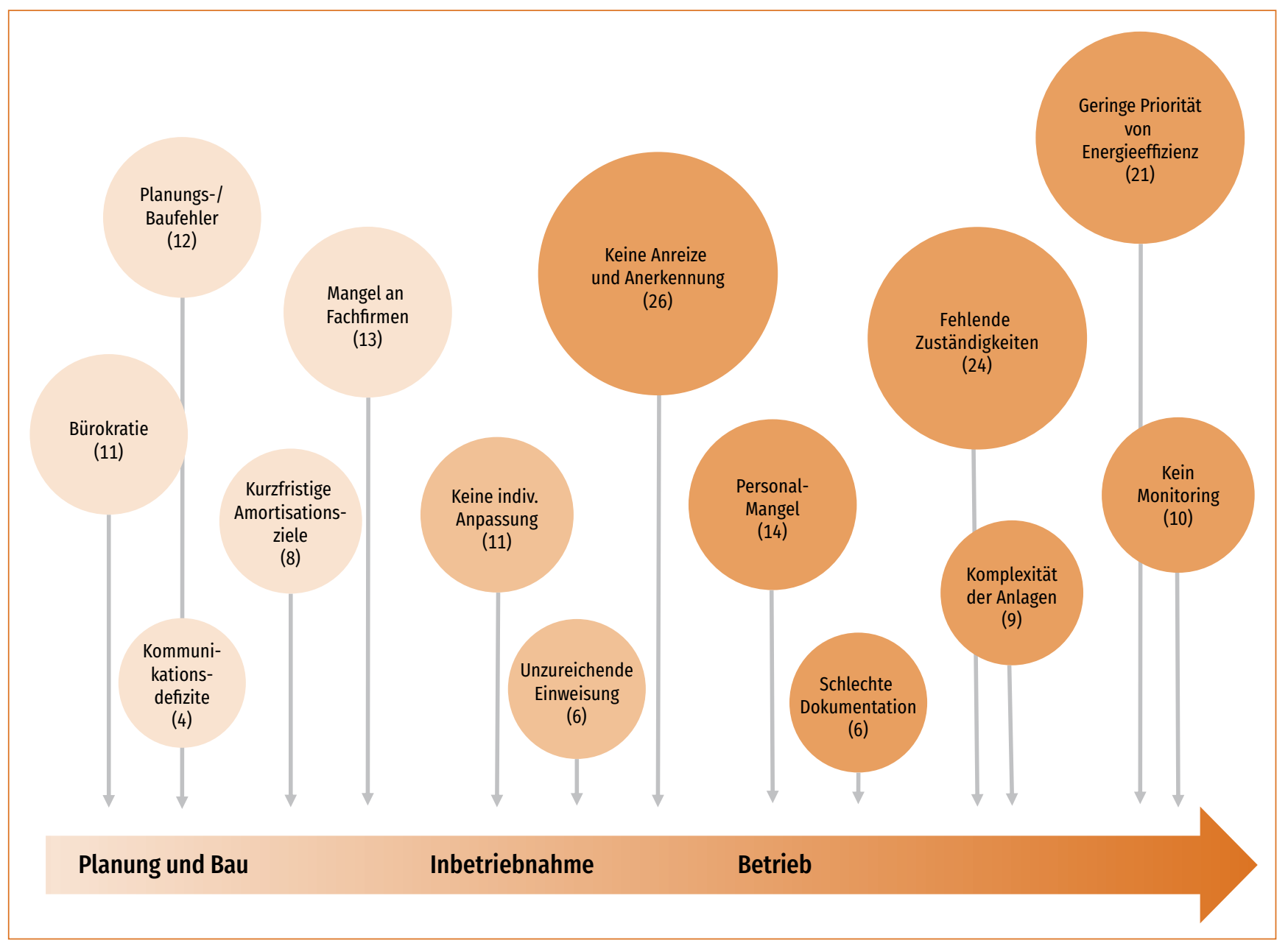

Abb.1: Typische Hemmnisse für den energieeffizienten Anlagenbetrieb. Anzahl der Nennungen: 27 Fälle, darunter 15 Liegenschaften und 12 Expertinneninterviews.

tung und Instandsetzung durchgeführt. Ziel der Veranstaltungen war es, auf Grundlage der in den Befragungen identifizierten Hemmnisse, Ansätze für praxistaugliche Lösungen zu entwickeln. Die Ergebnisse der Workshops wurden protokolliert und in die Analyse einbezogen.

\section{Ergebnisse}

\section{„Es ist eben nicht so ein Selbstläufer.“ \\ - Experte Anlagenplanung}

In allen betrachteten Liegenschaften wurden technische Fehler, die langfristig zu einem ineffizienten Anlagenbetrieb führen sowie ungünstige organisatorische Bedingungen identifiziert. Es zeigte sich, dass ein ineffizienter Anlagenbetrieb meist auf arbeitsorganisatorische Aspekte zurückzuführen ist. Eine Übersicht über die in den Befragungen geäußerten Hemmnisse, die teilweise eng zusammenhängen, bietet Abbildung 1.
Die oben genannten Akteursgruppen setzen in ihrer Beurteilung der hemmenden Faktoren unterschiedliche Schwerpunkte. Während z. B. Gebäude- und Energiemanager*innen eher Prioritäten und Anforderungen ihrer Institutionen thematisierten, schilderten Anlagenbetreuer*innen vor allem konkrete Probleme der Arbeitsorganisation. Pro Liegenschaft wurden angeführte Hemmnisse nur einmal erfasst, auch wenn sie von mehreren Interviewpartner*innen angesprochen wurden. Als wesentliche Faktoren erwiesen sich das Fehlen materieller und ideeller Anreize für Einsparungen, ungeregelte Zuständigkeiten für den energieeffizienten Betrieb der Anlagen sowie eine geringe Priorität von Energieeffizienz im Vergleich zu anderen Anforderungen.

In keiner der untersuchten Liegenschaften existieren maßgebliche Anreize für Einsparungen und persönliches Engagement wird nicht ausreichend gewürdigt (eine Energiemanagerin: „Der Haushaltstitel ist ausreichend bestückt und deshalb interessiert es niemanden, ob wir noch etwas sparen."). Als grundsätzliches Problem erwies sich weiterhin, dass Energieeffizienz primär der Technik zugeschrieben und meist nicht als kontinu- 
ierliche Aufgabe für das Personal, das für den laufenden Anlagenbetrieb verantwortlich ist, betrachtet wird. Überwiegend wird davon ausgegangen, die installierte Wärmetechnik sei entsprechend der Planung ,,automatisch“ und weitgehend ohne $\mathrm{Zu}$ tun effizient. Daher bestehen diesbezüglich i. d. R. keine verbindlichen Zuständigkeiten. Die Aufgabe der Beschäftigten in den Liegenschaften ist es, einen störungsfreien Betrieb sicherzustellen, bislang jedoch kaum, den energieeffizienten Betrieb zu unterstützen (eine Expertin aus der Energieeffizienzberatung: „Die Hauptsache ist, es ist warm, keiner meckert und das Gebäude kann betrieben werden. Das ist das Wichtigste."). Um die Störungsfreiheit zu gewährleisten und Nutzerbeschwerden $\mathrm{zu}$ vermeiden, werden die Anlagen vielfach mit ineffizienten Einstellungen oder in unnötigem Dauerbetrieb betrieben. Meist werden auch bei der Installation vorgenommene Einstellungen nicht an veränderte Bedarfe angepasst und es erfolgt kein Monitoring, so dass ineffiziente Betriebsweisen mitunter jahrelang nicht auffallen. Nur vier von 16 befragten Anlagenbetreuer*innen kümmern sich aktiv um einen effizienten Anlagenbetrieb, vor allem, weil ihre Vorgesetzten dies erwarten. Auch die befragten Gebäude- und Energiemanager*innen gaben ausnahmslos an, sich nicht hinreichend um die Effizienz einzelner Anlagen kümmern zu können. So äußerte beispielsweise ein Gebäudemanager: „Primär ist die Versorgungssicherheit wichtig und dann kommt erst die Effizienz." Hinzu kommt, dass in den vergangenen Jahren in vielen Bereichen Personal abgebaut wurde und daher in ca. der Hälfte der Liegenschaften keine ausreichenden personellen Ressourcen zur Verfügung stehen. Eine Gebäudemanagerin kommentierte: „Eigentlich kennt sich niemand mit der Anlage aus. Man hat nicht die Leute oder die Zeit, die Effizienz der Wärmeanlagen i.d. R. von niemandem mehr hinterfragt.

Zusammenfassend kann festgehalten werden, dass die arbeitsorganisatorischen Bedingungen einen effizienten Anlagenbetrieb vielfach behindern und wesentlich dazu beitragen, dass die technischen Möglichkeiten der Anlagen nicht ausgeschöpft werden.

\section{Lösungsansätze \\ „Es geht alles über den Faktor Mensch.“ \\ - Energiemanager}

Anhand positiver Beispiele aus den betrachteten Liegenschaften wird deutlich, dass der energieeffiziente Betrieb von Heizungsanlagen durch eine Ausrichtung der Arbeitsorganisation auf dieses Ziel hin wesentlich verbessert und langfristig sichergestellt werden kann. Von 15 analysierten Fällen erwiesen sich fünf hinsichtlich der Ausrichtung des soziotechnischen Systems auf Energieeffizienz als positiv. In diesen Liegenschaften sind folgende Bedingungen hervorzuheben:

- hohe Priorität von Energieeffizienz: Es existieren konkrete Energiesparziele, die von der Leitungsebene gegenüber den Beschäftigten regelmäßig kommuniziert werden. Die Leitungsebene fordert Energieeinsparungen ein und unterstützt diese. Die Beschäftigten werden in Optimierungsmaßnahmen einbezogen, z. B. durch Verbesserungsvorschläge.

- verbindliche Zuständigkeiten in der Betriebsphase: Eine Person oder ein kleines Team ist für die Anlagen zuständig, wo-

\section{Verbindliche Zuständigkeiten sind für den effizienten Betrieb von Heizungsanlagen besonders wichtig.}

da so durchzusteigen." Vorgaben wie das Benennen von Energiemanager*innen oder das Erfassen von Anlagendaten werden zwar formal umgesetzt, entfalten aber aufgrund der Alltagspraxis (z. B. Ausbleiben der Datenauswertung und der Umsetzung von Optimierungsmaßnahmen) nicht die gewünschte Wirkung. Bei nahezu allen Befragten besteht diesbezüglich ein Problembewusstsein. Ein effizienter Betrieb der Anlagen wird als erstrebenswert betrachtet, es mangelt jedoch an den organisationalen Voraussetzungen (Energiesparzielen, Handlungsmöglichkeiten, personellen und finanziellen Ressourcen).

Auch externe Wartungs- und Instandsetzungsfirmen kümmern sich selten um Aspekte der Energieeffizienz, da dies vertraglich nicht vorgesehen ist und kaum nachgefragt wird. In erster Linie sind bislang die Anlagenplaner*innen, die nach den gesetzlichen Vorgaben (u. a. Energieeinsparverordnung EnEV) planen, für Energieeffizienz zuständig. Sie haben jedoch nur in der Planungsphase Einfluss. Nach Abschluss der Planung wird bei explizit auch der energieeffiziente Betrieb als Arbeitsaufgabe betrachtet wird. Die Zuständigen verfügen über adäquate Qualifikationen u. a. in den Bereichen Energie- und Versorgungstechnik, Gebäude- und Energietechnik, Heizungsund Lüftungsbau, Maschinenbau und Elektroninstallation.

- intensive Kommunikation zum Anlagenbetrieb: Zwischen den relevanten Akteuren der verschiedenen Ebenen erfolgt ein regelmäßiger Austausch in wöchentlichen Arbeitsbesprechungen. Alle für den Anlagenbetrieb wichtigen Informationen werden zusätzlich schriftlich dokumentiert (analog in einem Anlagenbuch oder/und mittels eines digitalen Systems).

Auf Grundlage dieser Befunde lassen sich folgende Empfehlungen für die Gestaltung der arbeitsorganisatorischen Bedingungen ableiten: Als besonders wichtig erscheint es, verbindliche Zuständigkeiten zu schaffen. Es sollte daher eine konkrete Person benannt werden, die für den energieeffizienten Betrieb 
der Anlage verantwortlich ist, ein regelmäßiges Monitoring vornimmt oder beauftragt und mit anderen relevanten Akteuren intensiv kommuniziert. Die Ausrichtung der Anlagentechnik auf einen effizienten Betrieb und dessen Aufrechterhalten sollte als Teil der Arbeitsprozesse verstanden und entsprechend mit personellen Ressourcen und Handlungsbefugnissen ausgestattet werden. Dies könnte intern (z. B. im Rahmen des Energiemanagements) durch Aufbau eigenen Know-hows oder durch einen externen Dienstleister (z. B. Energiespar-Contracting) erfolgen. Um die Priorität von Energieeffizienz im Anlagenbetrieb zu erhöhen, müssen attraktive Anreize geschaffen werden, z. B. durch eine finanzielle Beteiligung der Liegenschaften oder
Verantwortlichkeiten für Energieeffizienz, Kommunikation von Einsparzielen und erzielten Ergebnissen). Bei der Gestaltung von Energiezukünften darf sich Energieeffizienz also nicht auf die Installation effizienter Technik beschränken, sondern auch der Betrieb technischer Systeme sollte auf dieses Handlungsziel hin ausgerichtet werden. Es geht nicht nur darum, einen Transformationspfad durch technische Innovationen anzustoßen, sondern diesen in der Techniknutzung beständig aufrechtzuerhalten (Shove 2017).

Auch wenn hinsichtlich der Notwendigkeit, das bestehende Energiesystem zu transformieren, allmählich Konsens besteht und auf politischer Ebene bereits vielfältige Maßnahmen ini-

\section{Ungenügende arbeitsorganisatorische Bedingungen tragen wesentlich dazu bei, dass die technischen Möglichkeiten für Anlageneffizienz nicht ausgeschöpft werden.}

einzelner Organisationseinheiten an den erreichten Einsparungen in Form eines Prämiensystems, wie z. B. im Projekt fifty/ fifty (2018). Der Stellenwert von Energieeffizienz im Arbeitsalltag kann wesentlich durch die Leitungsebene beeinflusst werden, indem Vorgesetzte effizienzbezogene Maßnahmen unterstützen, diesbezüglich Ziele setzen, die für die jeweiligen Organisationseinheiten und Anlagenkomponenten operationalisiert werden, und entsprechendes Engagement anerkennen. In diesem Zusammenhang erscheint es auch wichtig, Energiesparziele und erreichte Einsparungen regelmäßig zu kommunizieren, um alle relevanten Akteure zum Mitwirken zu motivieren.

Weiterhin sollte die Phase der Inbetriebnahme optimiert werden, um sicherzustellen, dass die Technik tatsächlich an die spezifischen Bedingungen der Liegenschaften angepasst wird (statt Übernahme von Standardeinstellungen) und die zukünftig verantwortlichen Akteure ausführlich eingewiesen werden. Von den befragten Expert*innen wurde angeregt, dafür eine zusätzliche Leistungsphase in der Honorarordnung für Architekten- und Ingenieurleistungen (HOAI) festzuschreiben.

\section{Fazit}

Die empirischen Befunde verdeutlichen das Prinzip der verteilten Handlungsträgerschaft in soziotechnischen Konstellationen (Rammert 2016). Es wird daher dafür plädiert, Energieeffizienz als verteilte Handlung zwischen technischen und sozialen Akteuren zu betrachten, um auf dieser Grundlage Anlagentechnik und arbeitsorganisatorische Strukturen gestalten zu können, die dauerhaft zu Einsparungen beitragen. Dabei ist der Einbezug von sozialen Aspekten auf mehreren Ebenen notwendig: von der Ausschreibung und Planung über den Anlagenbetrieb und die Wartung bis zur passenden Rahmensetzung (z. B. Anreize und tiiert werden, zeigt die vorliegende Analyse, dass sich die allgemeinen Zukunftsvisionen in den betrachteten Liegenschaften bislang kaum in Veränderungen auf organisationaler Ebene widerspiegeln. Energieeffizienz wird bisher nicht hinreichend als Querschnittsaufgabe verschiedener Ebenen und Disziplinen betrachtet, wie z. B. von Axon et al. (2012) und Janda (2014) gefordert. Die derzeitigen arbeitsorganisatorischen Regelungen zur Betreuung technischer Anlagen sowie die Organisationsmuster und Anerkennungsmechanismen sind überwiegend auf die Sicherstellung eines störungsfreien Betriebs und auf kurzfristige Kosteneffizienz ausgerichtet - unabhängig von deren Energieeffizienz. Deutlich wird dies z. B. durch die mangelnde Anerkennung energieeffizienten Verhaltens und fehlende Zuständigkeiten für diesbezügliche Anforderungen. Die Arbeitsorganisation der Einrichtungen zielte in den letzten Jahren auf einen (vermeintlich) kostensparenden Abbau von Personal und eine starke Differenzierung von Arbeitsaufgaben ab. Dies erschwert die Verantwortungsübernahme für Anforderungen wie die Sicherstellung von Energieeffizienz. Erst allmählich wird erkannt, dass unter den Maßgaben der Energiewende eine Umorientierung notwendig ist, die auch eine veränderte Betriebspraxis umfasst. Anhand der Forschungsergebnisse wird deutlich, dass im Zuge der Transformation des Energiesystems weitreichende Änderungen der Rahmenbedingungen, der Anreizmechanismen und der Zuständigkeiten erforderlich sind, um die gewünschten Effekte zu erreichen.

\footnotetext{
Literatur

Akrich, Madeleine (1997): The De-scription of technical objects. In: Wiebke Bijker und John Law (Hg.): Shaping technology/building society. Studies in sociotechnical change. Cambridge, MA: MIT Press, S. 205-224. Axon, Colin; Bright, Susan; Dixon, Tim; Janda, Katy; Kolokotroni, Maria (2012): Building communities. Reducing energy use in tenanted commercial
} 
property. In: Building Research \& Information 40 (4), S. 461-472. DOI: 10.1080/09613218.2012.680701.

BBSR - Bundesinstitut für Bau-, Stadt- und Raumforschung (2019): Berücksichtigung des Nutzerverhaltens bei energetischen Verbesserungen. Online verfügbar unter https://www.bbsr.bund.de/BBSR/DE/Veroeffentlichungen/ BBSROnline/2019/bbsr-online-04-2019-dl.pdf;jsessionid=3C4D2C203CA45830 A29D2CBFAFED13B9.live11294?__blob=publicationFile\&v=2.pdf, zuletzt geprüft am 04.10.2019.

Böhm, Uta; Buchin, Oliver (2019): Auswirkungen von organisationsbezogenen Rahmenbedingungen auf die Effizienz von Heizungs- und Kälteanlagen. In: InfrastrukturRecht 1, S. 2-4.

BMU - Bundesministerium für Umwelt, Naturschutz und nukleare Sicherheit (2016): Klimaschutzplan 2050. Klimaschutzpolitische Grundsätze und Ziele der Bundesregierung. Frankfurt am Main: Zarbock. Online verfügbar unter www.bmu.de/fileadmin/Daten_BMU/Download_PDF/Klimaschutz/ klimaschutzplan_2050_bf.pdf, zuletzt geprüft am 21.05.2019.

BMWi - Bundesministerium für Wirtschaft und Energie (2018a): Energieeffizienz in Zahlen 2018. Frankfurt am Main: Zarbock. Online verfügbar unter www.bmwi.de/Redaktion/DE/Publikationen/Energie/energieeffizienz-inzahlen-2018.pdf?_-_blob=publicationFile\&v=12, zuletzt geprüft am 21.05.2019.

BMWi (2018b): Innovationen für die Energiewende. 7. Energieforschungsprogramm der Bundesregierung. Frankfurt am Main: Zarbock. Online verfügbar unter www.bmwi.de/Redaktion/DE/Publikationen/ Energie/7-energieforschungsprogramm-der-bundesregierung.pdf?_blob=publicationFile\&v=11, zuletzt geprüft am 21.05.2019.

dena - Deutsche Energie-Agentur GmbH (Hg.) (2017): Büroimmobilien. Energetischer Zustand und Anreize zur Steigerung der Energieeffizienz. Online verfügbar unter https://www.dena.de/fileadmin/dena/Dokumente/ Pdf/9196_Bueroimmobilien_Energetischer_Zustand_Anreize_Steigerung_ Energieeffizienz.pdf, zuletzt geprüft am 09.10.2019.

Janda, Kathryn (2014): Building communities and social potential. Between and beyond organizations and individuals in commercial properties. In: Energy Policy 67, S. 48-55. DOI: 10.1016/j.enpol.2013.08.058.

Pettersen, Ida; Verhulst, Elli; Valle Kinloch, Roberto; Junghans, Antje; Berker, Thomas (2017): Ambitions at work. Professional practices and the energy performance of non-residential buildings in Norway. In: Energy Research \& Social Science 32, S. 112-120. D0I: 10.1016/j.erss.2017.02.013.

Rammert, Werner (2016): Technik - Handeln - Wissen. Zu einer pragmatistischen Technik- und Sozialtheorie. Wiesbaden: Springer vS.

Ropohl, Günter (2009): Allgemeine Technologie. Eine Systemtheorie der Technik. Karlsruhe: KIT Scientific Publishing.

Shove, Elizabeth (2017): What is wrong with energy efficiency? In: Building Research \& Information 46 (7), S. 779-789. DOI: 10.1080/09613218.2017.1361746. Star, Susan (1999): The ethnography of infrastructure. In: American Behavioral Scientist 43 (3), S. 377-391. DOI: 10.1177/00027649921955326.

\section{Forschungsdaten und -projekte}

c.HANGE (2019): Handwerker gestalten die Energiewende. Online verfügbar unter https://www.ifeu.de/projekt/c-hange, zuletzt geprüft am 04.10.2019.

DACH - Energieeffiziente Stadt (2019): DACH. Eine Kooperation energieeffizienter Städte. Online verfügbar unter https://www.dach-energieeffiziente-stadt.eu/ index.php, zuletzt geprüft am 04.10.2019.

ENGITO (2019): Energieeinsparung durch gering-investive technische und organisatorische Maßnahmen in komplexen Wärme- und Kälteanlagen.
Online verfügbar unter https://www.tu-berlin.de/ztg/menue/projekte_und kompetenzen/projekte_laufend/engito_energieeinsparung_durch_gering_ investive_technische_und_organisatorische_massnahmen_in_komplexen_ waerme_und_kaelteanlagen/, zuletzt geprüft am 08.10.2019.

ENOB: dataNWG (2019): Forschungsdatenbank Nichtwohngebäude. Online verfügbar unter https://www.datanwg.de/home/aktuelles, zuletzt geprüft am 04.10.2019.

fifty/fifty (2018): Energiesparen an Schulen. Online verfügbar unter https://www.fifty-fifty.eu, zuletzt geprüft am 04.10.2019.

LowEx Bestand (2018): LowEx-Konzepte für die Wärmeversorgung von Mehrfamilien-Bestandsgebäuden. Online verfügbar unter http://www.lowexbestand.de/?lang=de, zuletzt geprüft am 04.10.2019.

UfU - Unabhängiges Institut für Umweltfragen e. V. (2017): Passivhausschulen werden aktiv. Online verfügbar unter https://www.ufu.de/projekt/ passivhausschulen, zuletzt geprüft am 04.10.2019.

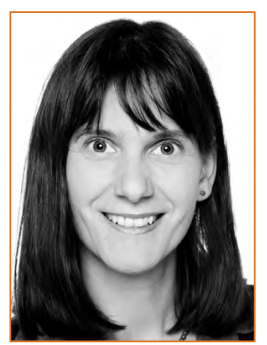

\section{UTA BÖHM}

ist Sozialwissenschaftlerin und arbeitet seit 2017 am Zentrum Technik und Gesellschaft der TU Berlin. Als Wissenschaftliche Mitarbeiterin des Forschungsprojektes ENGITO beschäftigt sie sich mit techniksoziologischen Analysen zur Effizienz von Energieanlagen.

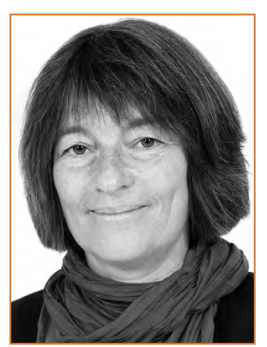

\section{PROF.DR.DR. MARTINA SCHÄFER} ist seit 2010 Wissenschaftliche Geschäftsführerin des Zentrums Technik und Gesellschaft der TU Berlin. Sie ist Biologin, Soziologin und Umwelttechnikerin. Ihre Forschungsschwerpunkte sind nachhaltiger Konsum, sozialwissenschaftliche Energieforschung sowie Methoden inter- und transdisziplinärer Forschung.

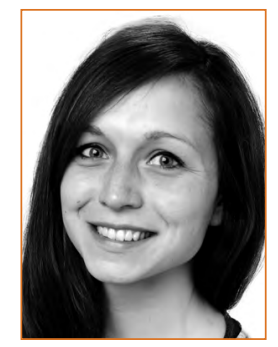

\section{MARIA STADLER}

ist Masterstudentin im Studiengang Soziologie Technikwissenschaftlicher Richtung an der TU Berlin. Seit 2018 ist sie als Studentische Mitarbeiterin im Forschungsprojekt ENGITO beschäftigt. 